Prepared in cooperation with the Delaware Department of Natural Resources and Environmental Control and the Delaware Geological Survey

\title{
Monitoring the Water-Quality Response of Agricultural Conservation Practices in the Bucks Branch Watershed, Sussex County, Delaware, 2014-16
}

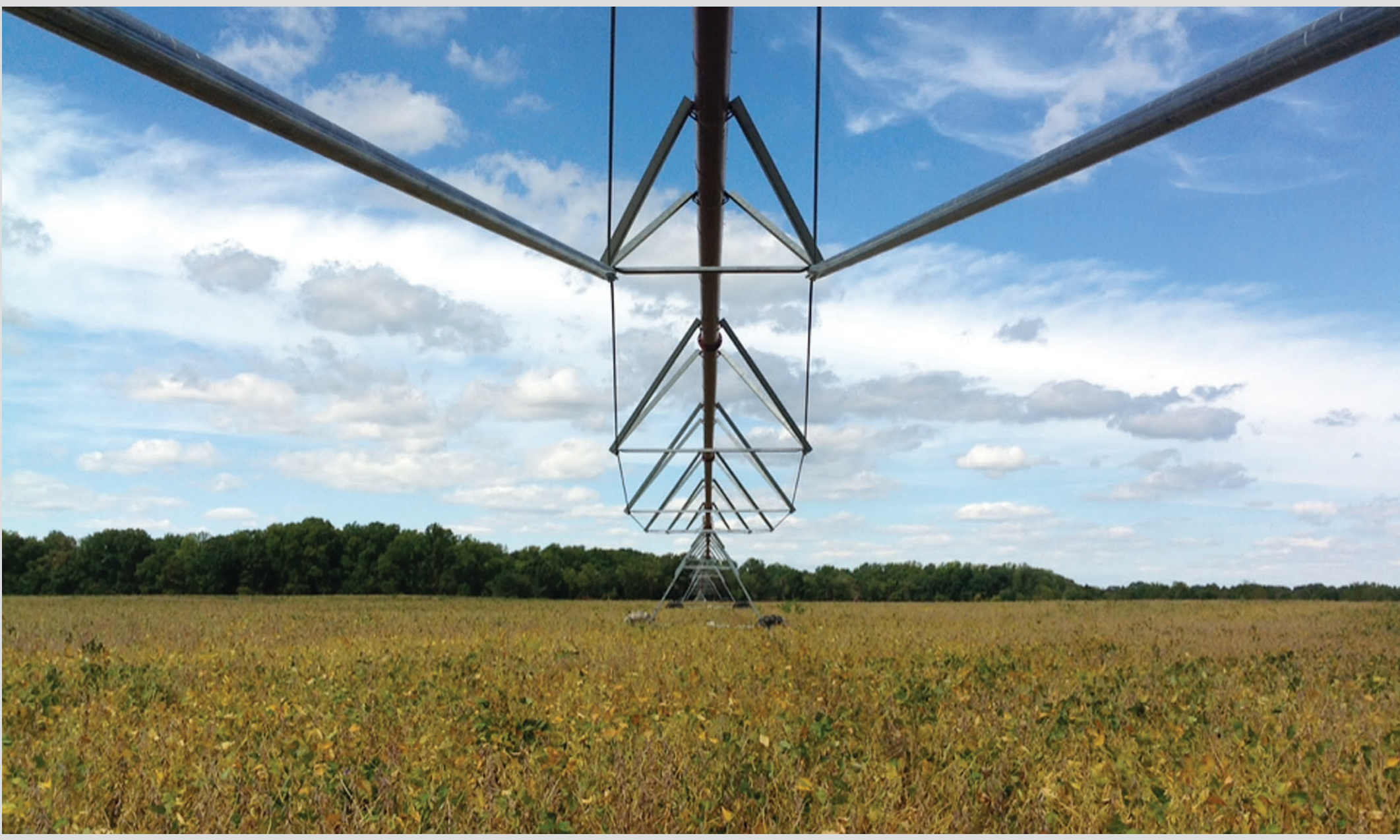

Scientific Investigations Report 2018-5020 
Cover. The Bucks Branch watershed is in a relatively flat, predominantly agricultural setting with with many fields that are irrigated. Photograph by John Clune, U.S. Geological Survey. 


\section{Monitoring the Water-Quality Response of Agricultural Conservation Practices in the Bucks Branch Watershed, Sussex County, Delaware, 2014-16}

By Judith M. Denver, Alexander M. Soroka, Betzaida Reyes, Todd R. Lester, Deborah A. Bringman, and Michael S. Brownley

Prepared in cooperation with the Delaware Department of Natural Resources and Environmental Control and the Delaware Geological Survey

Scientific Investigations Report 2018-5020 


\title{
U.S. Department of the Interior \\ RYAN K. ZINKE, Secretary
}

\author{
U.S. Geological Survey \\ James F. Reilly II, Director
}

U.S. Geological Survey, Reston, Virginia: 2018

For more information on the USGS - the Federal source for science about the Earth, its natural and living resources, natural hazards, and the environment-visit https://www.usgs.gov or call 1-888-ASK-USGS.

For an overview of USGS information products, including maps, imagery, and publications,

visit https://store.usgs.gov.

Any use of trade, firm, or product names is for descriptive purposes only and does not imply endorsement by the U.S. Government.

Although this information product, for the most part, is in the public domain, it also may contain copyrighted materials as noted in the text. Permission to reproduce copyrighted items must be secured from the copyright owner.

Suggested citation:

Denver, J.M., Soroka, A.M., Reyes, B., Lester, T.R., Bringman, D.A., and Brownley, M.S., 2018, Monitoring the water-quality response of agricultural conservation practices in the Bucks Branch watershed, Sussex County, Delaware, 2014-16: U.S. Geological Survey Scientific Investigations Report 2018-5020, 43 p., https://doi.org/10.3133/ sir20185020.

ISSN 2328-031X (print)

ISSN 2328-0328 (online) 


\section{Acknowledgments}

The Delaware Department of Natural Resources and Environmental Control (DNREC) funded this project under a cooperative agreement between the Delaware Geological Survey (DGS) and the U.S. Geological Survey (USGS). The authors extend sincere appreciation to the landowner who provided access for sampling and made this project possible. John Schneider, Hassan Mirsajadi, Marcia Fox, Kathy Knowles, Ben Pressley, John Cargill, and many other DNREC employees are thanked for their assistance and in-kind support during the project, especially for Geoprobe data collection and laboratory analysis. The University of Delaware Cooperative Extension, including Amy Shober and James Adkins and many others at the Carvel Research Center, also are thanked for their support and sharing of information, including soil moisture and irrigation data, and analysis of plant material. Clinton Church and Sarah Fishel of the U.S. Department of Agriculture, Agricultural Research Service (ARS) in University Park, Pennsylvania are thanked for soil analysis. 



\section{Contents}

Acknowledgments ……...................................................................................................................

Abstract

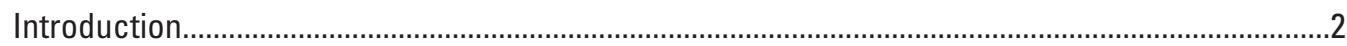

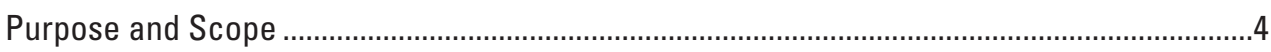

Description of Study Area .......................................................................................................

Crop Production Practices at the Bucks Branch Study Site, 2015 Growing Season ................5

Network Design, Sampling, and Analytical Methods .................................................................

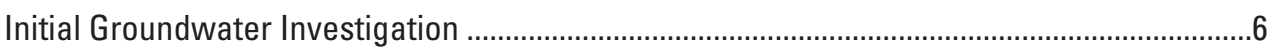

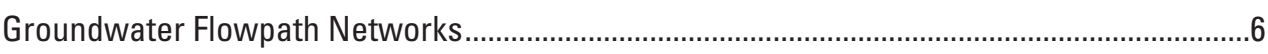

Groundwater Sampling Methods and Analysis ......................................................................

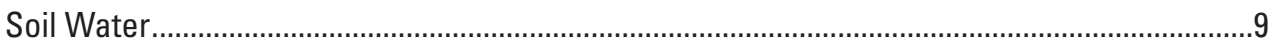

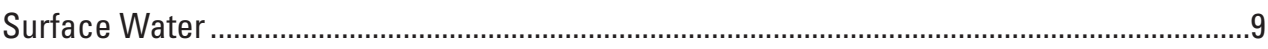

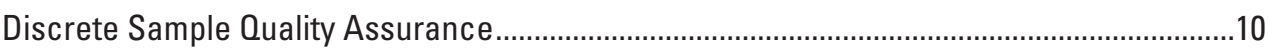

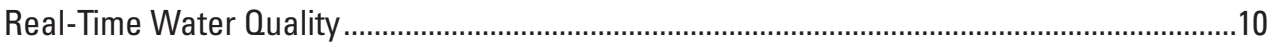

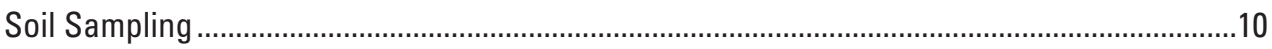

Cover-Crop Soil and Plant Data .......................................................................................

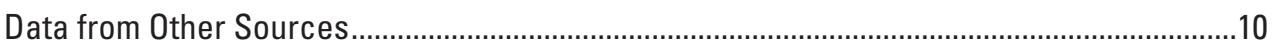

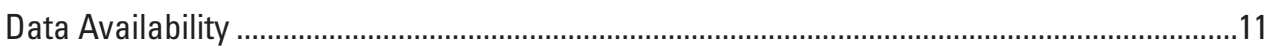

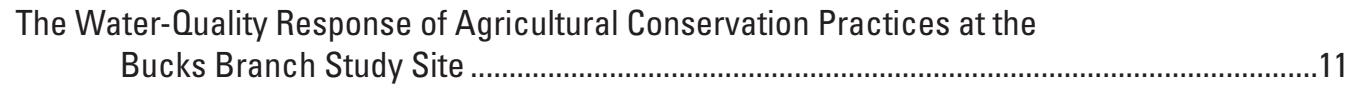

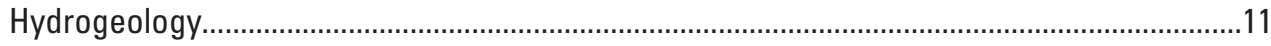

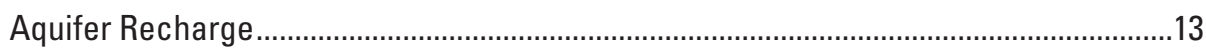

Apparent Age of Groundwater …………...................................................................... 14

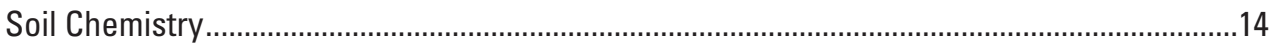

Water Chemistry in Groundwater and Soils .......................................................................15

Characterization of Groundwater Quality Using Temporary Wells ................................15

Transport of Water and Chemicals from Soil to Groundwater .........................................17

Transport of Nutrients through Groundwater to the Stream ...........................................22

Isotopes of Nitrate and Denitrification in Groundwater...........................................22

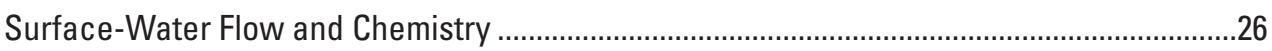

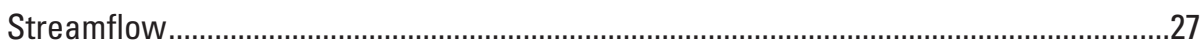

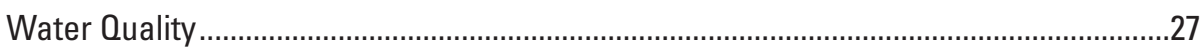

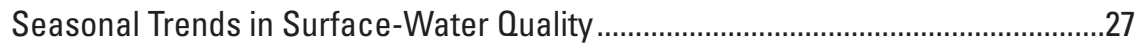

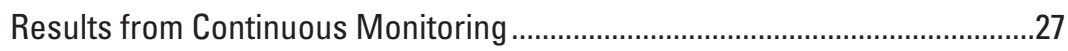

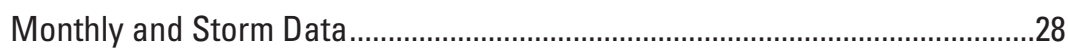

Effect of Groundwater on Surface Water in the Bucks Branch Watershed ..................31

Estimated Nitrate Loss to Bucks Branch Through Denitrification ...........................31

Comparison of the Intensive Surface-Water Site to Watershedwide Surface-

Water Quality in Bucks Branch.............................................................................33

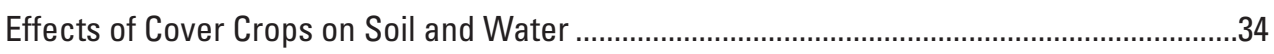

Summary and Conclusions.....................................................................................................

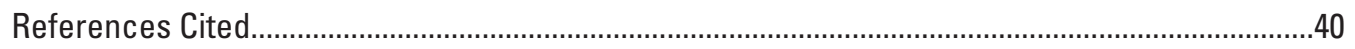




\section{Figures}

1. Map showing location of the study area, and land use and surface-water sites in the Bucks Branch watershed, Sussex County, Delaware...

2. Map showing location of temporary well points and water-table elevation in February 2014 at the Bucks Branch study site, Sussex County, Delaware.

3. Map showing location of groundwater flowpath networks, Bucks Branch study site, Sussex County, Delaware .

4. Cross sections showing groundwater flowpaths, the apparent age of groundwater, and the hydraulic-head gradients in flowpath wells beneath the $A$, dryland and

$B$, irrigated fields Bucks branch study site, Sussex County, Delaware, April 2016

5. Graphs showing continuous monitoring of water-table and stream elevation on the irrigated and dryland fields; and rainfall in Bridgeville, Delaware showing $A$, the effects of irrigation during the growing season, and $B$, groundwater recharge during the winter, Bucks Branch Study site, Sussex County, Delaware

6. Graphs showing comparison of soil moisture in the $A$, irrigated and $B$, dryland fields, Bucks Branch study site, Sussex County, Delaware, June and July 2015

7. Graph showing comparison of silica concentrations to the apparent age of groundwater from flowpath wells, Bucks Branch study site, Sussex County, Delaware

8. Graphs showing total Kjeldahl Nitrogen values in soil for $A$, the mean concentrations in samples near all wells shown for different sampling times on the dryland and irrigated fields, and $B$, for the three main sampling locations on the dryland and irrigated fields in the flowpath networks, Bucks Branch study site, Sussex County, Delaware.

9. Boxplots showing summary of selected water-quality constituents from the temporary wells installed on the irrigated and dryland fields at the Bucks Branch study site: $A$, boxplots of selected constituents, and $B$, selected constituents compared to increasing age as indicated by increasing concentrations of silica

10. Graphs showing samples of lysimeters and shallow groundwater showing trends over time in $A$, specific conductance, $B$, nitrate, and $C$, orthophosphate from the dryland and irrigated study fields, Bucks Branch study site, Sussex County,

Delaware, 2014-15.

11. Graphs showing comparison of concentrations of $A$, nitrate and $B$, orthophosphate to depth below land surface in lysimeters and wells from the Bucks Branch study site, Sussex County, Delaware

12. Graphs showing the relation between specific conductance and $\mathrm{pH}$, nitrate, orthophosphate, sulfate, calcium, magnesium, potassium, sodium, and chloride in $A$, lysimeter samples, and $B$, groundwater samples from the dryland and irrigated fields, Bucks Branch study site, Sussex County, Delaware.

13. Cross sections showing median concentrations of nitrate in groundwater beneath $A$, the dryland and $B$, the irrigated fields of the Bucks Branch study site, Sussex County, Delaware.

14. Boxplot showing concentration of nitrate as nitrogen in relation to the estimated apparent age of groundwater under the irrigated and dryland fields at the Bucks Branch study site, Sussex County, Delaware

15. Graph showing ratios of the nitrogen (delta ${ }^{15} \mathrm{~N}$ ) and oxygen (delta ${ }^{18} \mathrm{O}$ ) isotopes of nitrate in groundwater from the Bucks Branch study site, Sussex County, Delaware......

16. Graph showing streamflow at the gaged site SW2 during the study period, Bucks Branch study site, Sussex County, Delaware. 
17. Boxplots showing concentrations of $A$, phosphorus and $B$, nitrogen in surface water, site SW2, Bucks Branch study site, Sussex County, Delaware..

18. Graphs showing continuous monitoring data at site SW2 for $A$, specific conductance, $B$, dissolved oxygen, $C, \mathrm{pH}$, and $D$, temperature, site SW2, Bucks Branch study site, Sussex County, Delaware, February 2014 through September 2015.

19. Graphs showing concentrations of selected constituents over time in base flow and stormflow, site SW2, Bucks Branch study site, Sussex County, Delaware. . .30

20. Graph showing differences in the concentrations of nitrate in base flow at similar flow rates during the fall through winter and spring through summer, site SW2, Bucks Branch study site, Sussex County, Delaware...

21. Graphs showing trends in $A$, the ratio of the nitrogen (delta ${ }^{15} \mathrm{~N}$ ) and oxygen (delta ${ }^{18} \mathrm{O}$ ) isotopes of nitrate, and $B$, delta ${ }^{15} \mathrm{~N}$ and nitrate in water by season and flow conditions, site SW2, Bucks Branch study site, Sussex County, Delaware

22. Graph showing spring base-flow synoptic sampling showing relation of streamflow to nitrate concentrations in surface water collected around the Bucks Branch watershed, Sussex County, Delaware, 2014-16.

23. Graphs showing nutrient data by month for the watershed outlet at SW1, Bucks Branch, Sussex County, Delaware, 2003-12.

24. Photographs showing alternating rows of rye and radish at the study site with a radish shown on the right to demonstrate the possible size of a radish tuber in the irrigated field, Bucks Branch study site, Sussex County, Delaware

25. Graph showing nitrate as nitrogen concentrations for shallow and medium depth wells and soil-water lysimeters over time from irrigated and dryland fields at the Bucks Branch study site, Sussex County, Delaware..

26. Graphs showing soil-water samples of $A$, nitrate as nitrogen and $B$, dissolved organic nitrogen from irrigated and dryland fields at the Bucks Branch study site, Sussex County, Delaware.

\section{Tables}

1. Data for temporary wells installed and sampled at the Bucks Branch study site, Sussex County, Delaware.

2. Mean Total Kjeldahl Nitrogen values for soils collected at various depths for the dryland and irrigated fields for all sampling locations at the Bucks Branch study site, Sussex County, Delaware

3. Summary statistics for water samples from January and February 2014 in temporary wells installed on the study fields in the Bucks Branch study site, Sussex County, Delaware.

4. Multivariate correlations of groundwater samples from the dryland and irrigated fields, Bucks Branch study site, Sussex County, Delaware...

5. Correlation between specific conductance, and nutrients and major ions in samples from lysimeters, Bucks Branch study site, Sussex County, Delaware.

6. Summary statistics for samples from flowpath wells, instream piezometers, and the intensive stream site (SW2), Bucks Branch study site, Sussex County, Delaware..25

7. Mixing model input data and model output used for estimating the loss of nitrate from groundwater discharging to surface water at site SW2, Bucks Branch, Sussex County Delaware 
8. Cover crop biomass nutrient content prior to radish die-off from freezing and following radish die-off in the irrigated field at the Bucks Branch study site,

Sussex County, Delaware.

9. Cover crop biomass nutrient content prior to radish die-off from freezing and following radish die-off in the dryland field at the Bucks Branch study site, Sussex County, Delaware..

10. Soil fertility results for the top foot of soil from the dryland and irrigated fields associated with the Bucks Branch study site, Sussex County, Delaware

\section{Conversion Factors}

U.S. customary units to International System of Units

\begin{tabular}{|c|c|c|}
\hline Multiply & By & To obtain \\
\hline \multicolumn{3}{|c|}{ Length } \\
\hline inch of water column & 0.024 & centibars (cb) \\
\hline inch (in.) & 2.54 & centimeter $(\mathrm{cm})$ \\
\hline inch (in.) & 0.3048 & meter $(\mathrm{m})$ \\
\hline foot $(\mathrm{ft})$ & 0.3048 & meter $(\mathrm{m})$ \\
\hline mile (mi) & 1.609 & kilometer $(\mathrm{km})$ \\
\hline \multicolumn{3}{|c|}{ Area } \\
\hline acre & 0.4047 & hectare (ha) \\
\hline square mile $\left(\mathrm{mi}^{2}\right)$ & 2.590 & square kilometer $\left(\mathrm{km}^{2}\right)$ \\
\hline \multicolumn{3}{|c|}{ Flow rate } \\
\hline cubic foot per second $\left(\mathrm{ft}^{3} / \mathrm{s}\right)$ & 0.02832 & cubic meter per second $\left(\mathrm{m}^{3} / \mathrm{s}\right)$ \\
\hline \multicolumn{3}{|c|}{ Mass } \\
\hline ounce, avoirdupois (oz) & 28.35 & $\operatorname{gram}(\mathrm{g})$ \\
\hline pound, avoirdupois (lb) & 0.4536 & kilogram (kg) \\
\hline ton, short $(2,000 \mathrm{lb})$ & 0.9072 & metric ton $(\mathrm{t})$ \\
\hline ton, long $(2,240 \mathrm{lb})$ & 1.016 & metric ton $(\mathrm{t})$ \\
\hline \multicolumn{3}{|c|}{ Hydraulic gradient } \\
\hline foot per mile (ft/mi) & 0.1894 & meter/kilogram (m/kg) \\
\hline \multicolumn{3}{|c|}{ Transmissivity } \\
\hline foot squared per day $\left(\mathrm{ft}^{2} / \mathrm{d}\right)$ & 0.09290 & meter squared per day $\left(\mathrm{m}^{2} / \mathrm{d}\right)$ \\
\hline \multicolumn{3}{|c|}{ Application rate } \\
\hline pounds per acre per year (lb/acre/yr) & 1.121 & kilogram per hectare per year $(\mathrm{kg} / \mathrm{ha} / \mathrm{yr})$ \\
\hline
\end{tabular}

Temperature in degrees Fahrenheit $\left({ }^{\circ} \mathrm{F}\right)$ may be converted to degrees Celsius $\left({ }^{\circ} \mathrm{C}\right)$ as follows:

$$
{ }^{\circ} \mathrm{C}=\left({ }^{\circ} \mathrm{F}-32\right) / 1.8
$$




\section{Datum}

Vertical coordinate information is referenced to the North American Vertical Datum of 1988 (NAVD 88).

Horizontal coordinate information is referenced to the North American Datum of 1983 (NAD 83).

Elevation, as used in this report, refers to distance above the vertical datum.

Specific conductance is given in microsiemens per centimeter at 25 degrees Celsius $(\mu \mathrm{S} / \mathrm{cm}$ at $\left.25^{\circ} \mathrm{C}\right)$.

Concentrations of chemical constituents in water are given in either milligrams per liter (mg/L) or micrograms per liter $(\mu \mathrm{g} / \mathrm{L})$.

\section{Abbreviations}

DEOS

DGS

DNREC

EPA

UD

USDA ARS

USGS
Delaware Environmental Observing System

Delaware Geological Survey

Department of Natural Resources and Environmental Control

U.S. Environmental Protection Agency

University of Delaware

U.S. Department of Agriculture Agricultural Research Service

U.S. Geological Survey 



\title{
Monitoring the Water-Quality Response of Agricultural Conservation Practices in the Bucks Branch Watershed, Sussex County, Delaware, 2014-16
}

\author{
By Judith M. Denver, Alexander M. Soroka, Betzaida Reyes, Todd R. Lester, Deborah A. Bringman, and \\ Michael S. Brownley
}

\section{Abstract}

The purpose of this study was to evaluate the effects of irrigation and cover crops as conservation practices on water quality in groundwater and streams. Bucks Branch, a stream in the Nanticoke River watershed in southwestern Delaware, was identified as having one of the highest concentrations of nitrate in all surface-water sites sampled by the Delaware Department of Natural Resources and Environmental Control (DNREC). The study site is on two adjacent fields bordering Bucks Branch, one that has used irrigation since 2000 and one with dryland farming; both under conservation tillage and long-term rotation of corn, soybean, and small grain crops. A streamgage was installed near the study site fields to measure streamflow and water quality. The study area is typical of farming practices and environmental conditions throughout much of the intensively farmed agricultural land of the Coastal Plain of Delaware and surrounding parts of Maryland. Monitoring was conducted from January 2014 through June 2016. Corn was grown on both fields during the two growing seasons of the study period, and cover crops were planted before or shortly after harvest on both fields. During the second year of data collection, the effects of radish and rye grass cover crops on nutrient transport were studied.

The combined results from data collected for this study show that water and nitrate moved below the root zone year round when soil moisture was high, especially after significant rainfall and frequently after irrigation. Soil water sampled 2 to 3 weeks after nutrients were applied had nitrate concentrations greater than 50 milligrams per liter as nitrogen $(\mathrm{mg} / \mathrm{L}$ as $\mathrm{N}$ ) and may be a significant source of nitrate to groundwater. Whereas recharge containing elevated nitrate concentrations also occurred under the dryland field, it was less frequent and of lower concentration than recharge under the irrigated field.

Nitrate was present in all groundwater samples from these sites. Groundwater estimated to have recharged within 10 years or less had higher median concentrations of nitrate than in older water samples. The oldest groundwater encountered was over 30 years old, and had traveled along the longest, deep flowpaths from upland fields to the stream.
The median nitrate concentration was $18 \mathrm{mg} / \mathrm{L}$ as $\mathrm{N}$ in younger water (less than 10 years old) beneath the irrigated field, compared to about $10 \mathrm{mg} / \mathrm{L}$ as $\mathrm{N}$ in younger water beneath the dryland field. Samples from the shallow upland wells in both study fields showed little, if any, evidence of denitrification. Several samples from deeper wells and from wells near forested riparian zone wetlands that border both fields did show partial denitrification.

A mixing model estimated that between 12 and 22 percent of the nitrate discharging to the stream was lost through uptake and denitrification upstream of the streamgage on Bucks Branch. Continuous data collected at this site and evidence of denitrification in the surface-water samples showed a greater potential for loss of nitrate during the warmer months than the colder months. This pattern was similar to that seen below the streamgage at the most downstream site in the watershed.

A mixed cover crop of radishes and rye was planted prior to removal (radishes) and just after harvest (rye) of the corn crop on the irrigated field. Rye grass was planted shortly after crop harvest on the dryland field. Cover crop biomass samples collected while radishes were growing and after they were killed by freezing temperatures indicates that the early planted radish crop effectively scavenged available nitrogen from the soil. Whereas radish biomass initially held more nitrogen than rye, at 55 to 8 pounds per acre, respectively, leaching of inorganic nitrate following radish die-off was minimal. Soilwater nitrate concentrations during the cover-crop growing period were lower than during the growing season prior to planting of the cover crop. There also was an increase in soil fertility and dissolved organic nitrate in samples of soil water that was likely related to increased soil microbial metabolism. Results indicate that cover crops stored plant nutrients over the winter and did not increase shallow groundwater concentrations of nitrate.

Although conservation practices such as cover crops and nutrient management have been applied to these fields, there was still significant leaching of nitrate to groundwater, especially under the irrigated field. This will likely continue to be a challenge in this area and other parts of the Coastal Plain 
where soil moisture capacity is relatively low and managing irrigation around rainfall is difficult. Cover crops, when planted in standing corn, are one practice that can effectively pull nitrate from below the root zone to the top layer of soil, thus limiting the amount of potential nitrate leaching to groundwater. Irrigation management that would lower average soil moisture conditions during the growing season also could potentially limit nitrogen transport.

\section{Introduction}

The Delaware Department of Natural Resources and Environmental Control (DNREC) has collected water-quality data throughout the Nanticoke River watershed in Delaware to better understand the distribution of elevated nutrient concentrations in groundwater and surface water and to identify areas where management efforts should be targeted. These data identified Bucks Branch as having one of the highest concentrations of nitrate in surface water of all sites sampled by DNREC (fig. 1). This stream receives excessive amounts of nutrients and sediment from both agricultural and residential sources and is on Delaware's 303(d) list of impaired water bodies (Delaware Department of Natural Resources and Environmental Control, 2017). The State of Delaware's Total Maximum Daily Load (TMDL) developed for this watershed requires a 30-percent and 50-percent reduction in nitrogen and phosphorus loads, respectively.

In a recent study, the U.S. Geological Survey (USGS) and DNREC provided initial information about the transport and fate of nitrate within the Bucks Branch watershed (Clune and Denver, 2012). Concentrations of nitrate exceeded the U.S. Environmental Protection Agency (EPA) drinking water standard (10 milligrams per liter as nitrogen, or $\mathrm{mg} / \mathrm{L}$ as N) in 60 percent of groundwater samples and 42 percent of surface-water samples. Geochemical analyses indicated that agriculture is the predominant source of nitrate contamination in Bucks Branch. The median apparent age of sampled groundwater was 18 years, and the estimated average residence time of groundwater contributing to the streamflow for the entire Bucks Branch watershed at the outlet was approximately 19 years. This study provided a basic understanding of water-quality conditions from past management practices and a general understanding of the residence time of water in this system. Resource managers would like to better evaluate how current conservation practices, such as irrigation and cover crops, are affecting shallow groundwater and how long it will take to see these potential effects in streams.

Agronomic studies in corn production areas have long shown that irrigation significantly raises crop yields, despite variability in annual weather conditions (Al-Kaisi and Yin, 2003; Eck, 1984; Olson and others, 1964). A proposed benefit of irrigation is its ability to raise the nitrogen consumption of irrigated corn (Al-Kaisi and Yin, 2003; Bushong and others, 2014; Kim and others, 2008). A more efficient use of nitrogen

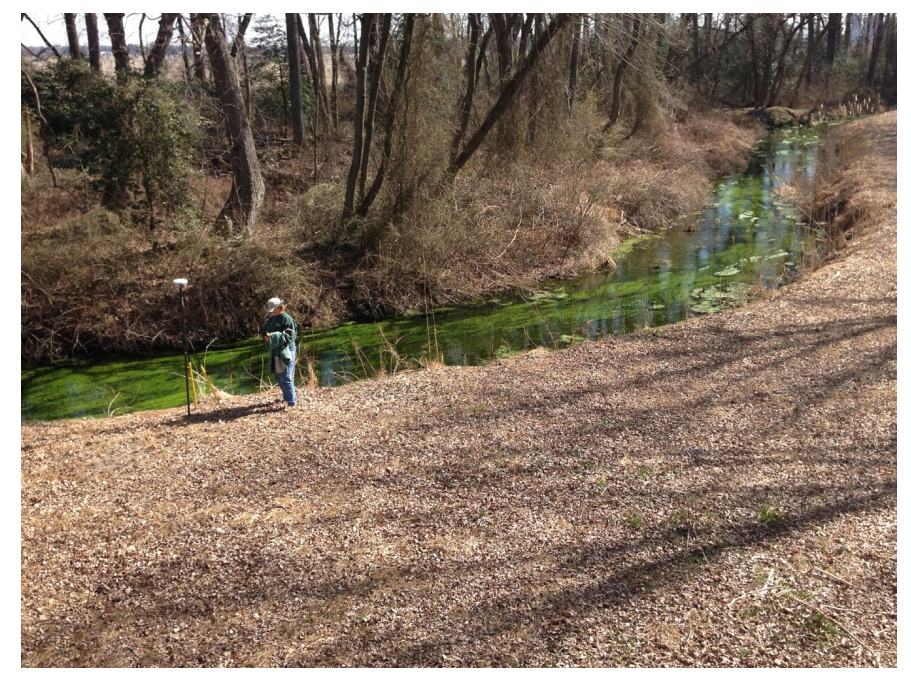

Growth of aquatic vegetation in the Bucks Branch stream channel, March 2014. Photograph by Mark Nardi, U.S. Geological Survey

by plants under irrigated land is hypothesized to lower the amount of residual nitrogen available in soil that would eventually leach to groundwater. The use of irrigation on cropland has expanded to cover over 25 percent of all cropland in Delaware due to its yield-stabilization potential and economic benefit to farmers (University of Delaware, 2017). The implementation of irrigation and statewide yield stability has been encouraged by the Delaware Economic Development Office through the Delaware Rural Irrigation Program (DRIP), which provides small interest free loans to farmers for up to 7 years (Delaware Department of Agriculture, 2017). The rate of irrigation, weather conditions, and crop growth are deciding factors in determining whether irrigation assists in either nitrogen leaching or crop plant consumption (Agostini and others, 2010; Eck, 1984; Randall and Mulla, 2001; Zhang and others, 2005). Previous studies in the Mid-Atlantic region indicate that irrigation could increase groundwater nitrate concentrations in the eastern United States (Ritter and others, 1993; Ritter and others, 1991).

Cover crops are considered one of the most important agricultural conservation practices due to their ability to prevent topsoil erosion, increase soil organic matter, retain nutrients, and alleviate soil compaction. A large body of research indicates that cover crops reduce nutrient losses from agricultural lands (Dean and Weil, 2009; Jackson and others, 1993; Kristensen and Thorup-Kristensen, 2004; Staver and Brinsfield, 1998; Weinert and others, 2002). Cover crops potentially lower nitrate concentrations in groundwater by holding nitrogen in the soil zone for use by the subsequent crops. The variety of planted crop is important as studies comparing rye and radish crops indicated that radishes could be more effective than rye at scavenging deep soil nitrogen (Kristensen and Thorup-Kristensen, 2004), but could leach higher nitrate concentrations in sandy soils of the Coastal Plain following winter die-off of the cover crop (Dean and Weil, 2009). 

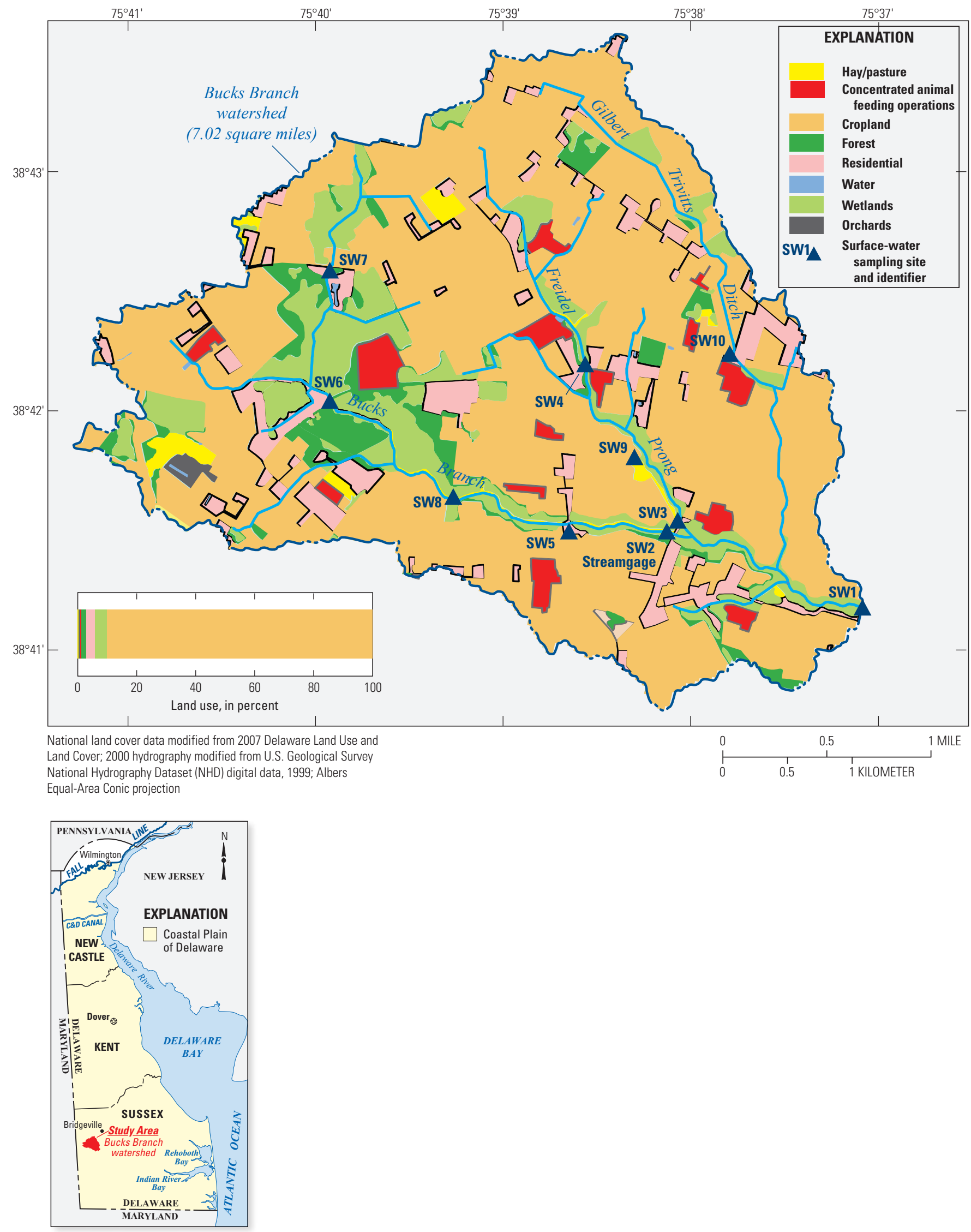

Figure 1. Location of the study area, and land use and surface-water sites in the Bucks Branch watershed, Sussex County, Delaware. 


\section{Purpose and Scope}

The purpose of this report was to evaluate the effects of current conservation practices on water quality in the Bucks Branch watershed. Specific conservation practices that were studied include the effects of irrigation on nutrient transport to groundwater compared to nutrient transport under dryland farming, and the effect of cover crops on nutrient transport. Surface-water quality and the transport of nutrients to surface water also were studied as part of this project.

Study networks on two adjacent fields, one with irrigation and one with dryland farming (both under conservation tillage), and a streamgage were established for monitoring of soil, shallow groundwater, and surface water. Monitoring was conducted from January 2014 through June 2016. Corn was grown on both fields during the two growing seasons of the study period and cover crops were planted at or near the end of each growing season on both fields. The potential differences between a cover crop mix (radish and rye) and a monocrop (rye) on the- soil and soil-water chemistry were studied during the second year of data collection.

Results from data collected during this study are described. Data collection included groundwater levels, both continuous and discrete, and samples for chemical analysis; samples of unsaturated zone soil water and soils, surface-water flow, and water quality. Continuous discharge and continuous and discrete water quality were monitored at a streamflowgaging station near the groundwater study site to relate surface-water chemistry to groundwater inputs of nitrogen and instream processing of nitrogen and phosphorus. The spatial and temporal distribution of nutrients in groundwater and surface water were determined using these data. Data collected by DNREC at the outlet to the larger Bucks Branch watershed and synoptic streamflow data that were collected at multiple locations during spring base-flow conditions around the watershed were compared to results from the intensive study site.

\section{Description of Study Area}

Bucks Branch is a 7.02-square-mile $\left(\mathrm{mi}^{2}\right)$ watershed that flows into the Nanticoke River, which drains into the Chesapeake Bay (fig. 1). The area is underlain by sediments of the Beaverdam Formation, which consists mainly of fluvial and estuarine deposits of sand, gravel, silt, and clays, and contains a surficial unconfined aquifer (Andres, 1994). Soils are predominantly well-drained sandy loam (Soil Survey Staff, Natural Resources Conservation Service, 2016). The unconfined surficial aquifer is between 60 and 100 feet (ft) thick and the water table is 5 to $10 \mathrm{ft}$ below land surface (Andres and Klingbeil, 2006). The topography in the Bucks Branch watershed is relatively flat, with elevations that range from 30 to $50 \mathrm{ft}$ above sea level. In this area of the Coastal Plain, groundwater provides the largest contribution of freshwater flow in streams, and is the predominant influence on surface-water quality and the major source of nitrate (Lindsey and others, 2003; Shedlock and others, 1999; Spahr and others, 2010).

Previous studies have documented elevated levels of nitrate in groundwater and surface water of the Delmarva Peninsula (Andres, 1991; Denver, 1989; Denver and others, 2004; Hamilton and others, 1993) and within the Bucks Branch watershed (Clune and Denver, 2012). The application of fertilizer and manure from poultry has been cited as a major source of contamination in groundwater, with local contributions from septic systems (Ator and Denver, 2015; Denver, 1989; Ritter and Chirnside, 1982). The median concentration of nitrate in groundwater-dominated stream base flow on the Delmarva Peninsula was around $3 \mathrm{mg} / \mathrm{L}$ as N for samples collected in 2000 (Denver and others, 2004). In 1995, concentrations of nitrate in Bucks Branch were about $6 \mathrm{mg} / \mathrm{L}$ as N (USGS streamflow station 01487150, Bucks Branch near Atlanta, Delaware). Concentrations greater than $10 \mathrm{mg} / \mathrm{L}$ as $\mathrm{N}$ have been measured more recently in Bucks Branch (Clune and Denver, 2012).

Land use in the Bucks Branch watershed is predominantly agricultural, consisting mainly of cropland (90.1 percent) and concentrated animal feeding operations ( 0.8 percent), along with wetlands (4.1 percent), residential dwellings ( 2.6 percent), forest ( 1.9 percent) and other settings ( 0.5 percent) (fig. 1; Clune and Denver, 2012). Most wetlands are in a forested area along the main stem of Bucks Branch where the soils are poorly drained and less suited for agriculture (fig. 1). In addition, wetlands are present in the riparian zone along Bucks Branch and its main tributary, Freidel Prong. The watershed has been extensively channelized to improve the drainage of local uplands, which has created steep banks along most streambeds that often disconnect the stream from the local riparian wetlands, except during periods of high water table and high base flow in the stream. Ditches and tile drains added to drain agricultural fields extend from the stream into fields throughout the watershed.

Agriculture has primarily included poultry production and the cultivation of corn, soybeans, and small grains during the past 50 years. The vast majority of nutrient inputs to the land surface in this part of Sussex County, Delaware, are from manure and fertilizer. Irrigation is practiced on 35 percent of cropland in the Bucks Branch watershed; in Sussex County, over 45 percent of annually harvested cropland is irrigated (U.S. Department of Agriculture, National Agricultural Statistics Service, 2012).

Prior to and during the study period, the Bucks Branch study site had a nutrient management plan developed by the Sussex Conservation District based on general nutrient management recommendations made by the University of Delaware (UD) Cooperative Extension (University of Delaware, College of Agriculture and Natural Resources, 2017) (see text inset). Conservation tillage has been practiced for over 15 years on both fields. Other conservation practices utilized include nutrient management planning to enhance crop production and increase nutrient uptake, irrigation management, grassed buffers, and the planting of cover crops to retain soil 


\section{Crop Production Practices at the Bucks Branch Study Site, 2015 Growing Season}

Late February-Early March Soil fertility tests done by crop consultant

March 20 Cover crops terminated with herbicide prior to corn planting

April 2 Herbicide applied for weed control by GPS guided sprayer

April 24 Poultry litter applied and incorporated, 2 tons/acre

Poultry litter was applied using calibrated and GPS guided equip-

ment. Nitrogen applications of poultry litter estimated to account

for 60 pounds of available nitrogen for crops in the first year.

May 7-15 Corn planted with starter fertilizer

May 8 Herbicide applied for weed control by GPS guided sprayer

June 11 First irrigation event on corn crop

The corn crop was irrigated 10 times over the 2015 growing sea-

son with a total of about 5.6 inches of water applied.

June 7-15

Majority of nitrogen fertilizer applied to corn

165 pounds/acre to irrigated land

100 pounds/acre to dryland

June 1

Herbicide applied for weed control by GPS guided sprayer

July 8

Aerial fungicide application

August 17

Cover crops of radishes planted in the standing corn crop using an ex-

perimental air-seeder and then irrigated to water cover crop seeds

Mid-late September

Corn harvested and rye cover crop planted on both fields

Irrigated yield: 237.8 bushels/acre

Dryland yield: 164 bushels/acre

After corn harvest Corn residue cut and incorporated using turbo-tiller

Conservation practices used at Bucks Branch site to reduce erosion and promote soil health:

Residue and Tillage Management_-Strip Till, Cover Crops, Conservation Crop Rotation, Nutrient

Management, and Integrated Pest Management 
nutrients after the growing season and enhance soil fertility. Fields included in this study have been used to grow corn, soybeans, and small grains. During the study period in 2014 and 2015, corn was grown on both fields.

\section{Network Design, Sampling, and Analytical Methods}

Sampling at the Bucks Branch study site began in January 2014 and continued through June 2016. Data collection included groundwater levels and samples; samples of unsaturated zone soil water and soils; surface-water flow and water quality; and the collection of agronomic data on crop and cover-crop production. The UD Cooperative Extension collected additional data on soil moisture in both fields over the two growing seasons during which sampling took place. The farmer provided crop yield and irrigation data for 2015. Corn, plant, and grain samples were collected and analyzed for total nitrogen by the UD Cooperative Extension staff. Rainfall data were obtained from a site near Bridgeville, Delaware, approximately $3.5 \mathrm{mi}$ north of the study site that is operated by the Delaware Environmental Observing System (DEOS) (University of Delaware, 2017).

\section{Initial Groundwater Investigation}

Groundwater-flow direction and water quality were initially characterized in January and February 2014 using temporary well points installed with the DNREC Division of Waste and Hazardous Substances Geoprobe. To collect samples and water-level data, a well point with a 4-ft screen (referred to as a temporary well) was driven into the surficial aquifer at 19 locations around the study site (fig. 2). After the water table in the temporary wells stabilized and prior to sampling, depth to water was measured with an electric tape gage. Single temporary wells were installed near the water table at 11 locations; multiple wells were installed from near the water table at 15 - to 20 -ft intervals to depths of about $45 \mathrm{ft}$ at 7 locations (fig. 2; table 1). Thirty-two samples were collected and analyzed for field parameters, major ions, and nutrients.

Each temporary well was surveyed to determine its location and the elevation of the land surface. A general watertable map for the study site was derived using water levels from the shallowest temporary well at each site, along with water levels in adjacent ditches and determination of the elevation of adjacent streams acquired using a lidar dataset. This map was used to guide installation of flowpath network wells.

\section{Groundwater Flowpath Networks}

Based on flowpaths identified during temporary well mapping, networks of shallow permanent wells (9 to $25 \mathrm{ft}$ deep) were installed along a groundwater flowpath on both fields in April 2014 and augmented with deeper wells (30 to $75 \mathrm{ft}$ deep) in July 2015 (fig. 3). The transects consisted of clusters of multiple wells at different depths installed across each field with additional shallow wells placed east and west between well clusters (fig. 3). USGS drillers from Reston,

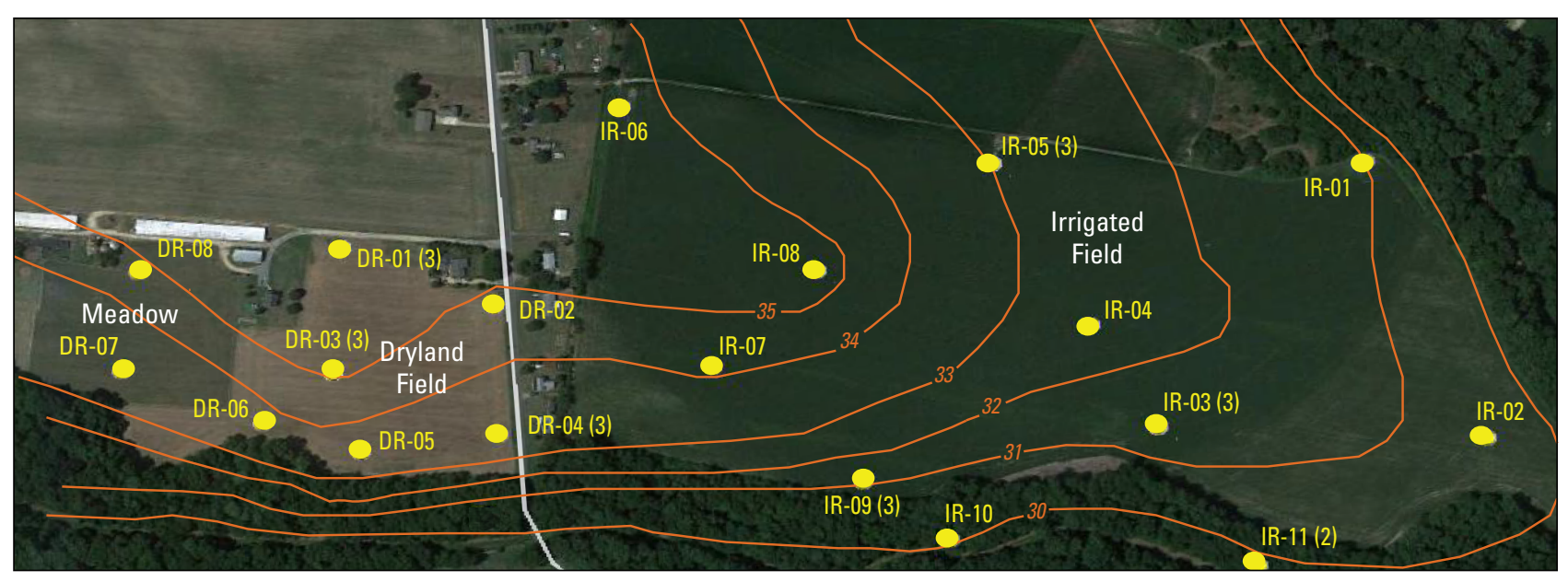

EXPLANATION

IR-11 (2) Location of temporary well and site number-

(2) Indicates number of depths drilled at site,

if greater than 1

-30 Water-table elevation, in feet-February 2014

Figure 2. Location of temporary well points and water-table elevation in February 2014 at the Bucks Branch study site, Sussex County, Delaware. 
Table 1. Data for temporary wells installed and sampled at the Bucks Branch study site, Sussex County, Delaware.

[ID, identification; depth, well depth; ft, feet; location of temporary wells shown on figure 2.]

\begin{tabular}{|c|c|c|c|}
\hline Well ID & Date & $\begin{array}{c}\text { Depth } \\
\text { (ft) }\end{array}$ & $\begin{array}{c}\text { Water level below } \\
\text { land surface } \\
\text { (ft) }\end{array}$ \\
\hline \multicolumn{4}{|c|}{ Dryland wells } \\
\hline DR01-1 & $2 / 27 / 2014$ & 12.0 & 6.49 \\
\hline DR01-2 & $2 / 27 / 2014$ & 22.1 & 7.51 \\
\hline DR01-3 & $2 / 27 / 2014$ & 42.0 & 10.65 \\
\hline DR02-1 & $2 / 27 / 2014$ & 16.0 & 7.05 \\
\hline DR03-1 & $2 / 26 / 2014$ & 16.7 & 9.44 \\
\hline DR03-2 & $2 / 26 / 2014$ & 25.2 & 9.8 \\
\hline DR03-3 & $2 / 26 / 2014$ & 36.7 & 10.0 \\
\hline DR04-1 & $2 / 11 / 2014$ & 12.8 & 5.3 \\
\hline DR04-2 & $2 / 11 / 2014$ & 25.6 & 5.2 \\
\hline DR04-3 & $2 / 11 / 2014$ & 45.1 & 5.8 \\
\hline DR05-1 & $2 / 11 / 2014$ & 9.5 & 4.64 \\
\hline DR06-1 & $2 / 11 / 2014$ & 13.1 & 5.73 \\
\hline \multicolumn{4}{|c|}{ Meadow wells } \\
\hline DR07-1 & $2 / 11 / 2014$ & 13.8 & 8.3 \\
\hline DR08-1 & $2 / 27 / 2014$ & 15.9 & 7.65 \\
\hline \multicolumn{4}{|c|}{ Irrigated wells } \\
\hline IR01-1 & $1 / 27 / 2014$ & 14.0 & 6.49 \\
\hline IR02-1 & $1 / 30 / 2014$ & 14.0 & 5.99 \\
\hline IR03-1 & $2 / 12 / 2014$ & 8.9 & 3.15 \\
\hline IR03-2 & $2 / 12 / 2014$ & 24.8 & 3.2 \\
\hline IR03-3 & $2 / 12 / 2014$ & 40.8 & 3.75 \\
\hline IR04-1 & $1 / 30 / 2014$ & 13.5 & 6.5 \\
\hline IR05-1 & $1 / 27 / 2014$ & 17.2 & 8.37 \\
\hline IR05-2 & $1 / 27 / 2014$ & 27.7 & 8.6 \\
\hline IR05-3 & $1 / 27 / 2014$ & 44.0 & 9.36 \\
\hline IR06-1 & $2 / 26 / 2014$ & 16.6 & 5.6 \\
\hline IR07-1 & $2 / 26 / 2014$ & 13.1 & 6.42 \\
\hline IR08-1 & $2 / 12 / 2014$ & 13.0 & 4.0 \\
\hline IR09-1 & $1 / 30 / 2014$ & 18.6 & 4.96 \\
\hline IR09-2 & $1 / 30 / 2014$ & 27.6 & 5.05 \\
\hline IR09-3 & $1 / 30 / 2014$ & 37.5 & 6.16 \\
\hline \multicolumn{4}{|c|}{ Streambank wells } \\
\hline IR10-1 & $2 / 6 / 2014$ & 11.4 & 2.62 \\
\hline IR11-1 & $2 / 6 / 2014$ & 11.3 & 2.42 \\
\hline IR11-2 & $2 / 6 / 2014$ & 21.3 & 5.47 \\
\hline
\end{tabular}

Virginia installed the wells using a hollow stem auger. The wells were constructed using 2-inch (in.) polyvinyl chloride (PVC) pipe with 3-ft PVC screens on the bottom of each well. The well network was sampled in the spring before fertilizer and manure application, and in the fall after crop removal during the study period. Wells were located directly in the fields and were constructed so that they could be buried during planting and harvest and brought back up for sampling. Temporarily burying the wells allowed the farmer to plant, fertilize, and harvest crops directly over the wells without leaving a barren area that could affect shallow water quality and reduce cropped acreage. Groundwater also was collected once along a transect across the streambed near the downstream end of the irrigated field flowpath using a stainless steel piezometer that was inserted into the streambed (fig. 3).

Water-level sensors for continuous measurement of groundwater levels were installed in three wells on the irrigated field, one well on the dryland field, and one well on the streambank downgradient of the irrigated field (fig. 3). Waterlevel equipment (if present) was removed when wells were buried and reinstalled after planting or harvest. All continuous and discrete groundwater-level data were collected and reviewed according to standard USGS procedures as outlined in Cunningham and Schalk (2011).

\section{Groundwater Sampling Methods and Analysis}

Groundwater samples collected from the flowpath network wells were analyzed for nutrients, major ions, the isotope composition of nitrate, and apparent age. Groundwater samples were collected prior to fertilizer and manure application in the spring, after crop removal in the fall of 2014-15, and in the spring of 2016. All samples were collected following protocols outlined in the USGS National Field Manual (U.S. Geological Survey, variously dated). Either a submersible gear-driven suction pump or a peristaltic pump was used to collect samples depending on water levels and the waterlevel recovery rate in the wells. Wells were purged until field parameters $(\mathrm{pH}$, specific conductance, water temperature, and dissolved oxygen) stabilized and the final readings were recorded. All water-quality data were collected and reviewed according to standard USGS procedures (U.S. Geological Survey, variously dated). Water samples for major ions and nutrients were analyzed at the DNREC Environmental Laboratory in Dover, Delaware. The DNREC laboratory participates in the USGS blind sample program, in which a comparison of analytical results between this lab and others across the Nation is performed. Results from the DNREC laboratory are approved by this program and a previous USGS Laboratory Evaluation Program that was used for the first study at this site (Clune and Denver, 2012).

The samples for major ions and nutrient chemistry were filtered onsite through a disposable filter with 0.45-micrometer $(\mu \mathrm{m})$ pore size and delivered to the DNREC Environmental Laboratory for analysis. Samples were analyzed for 


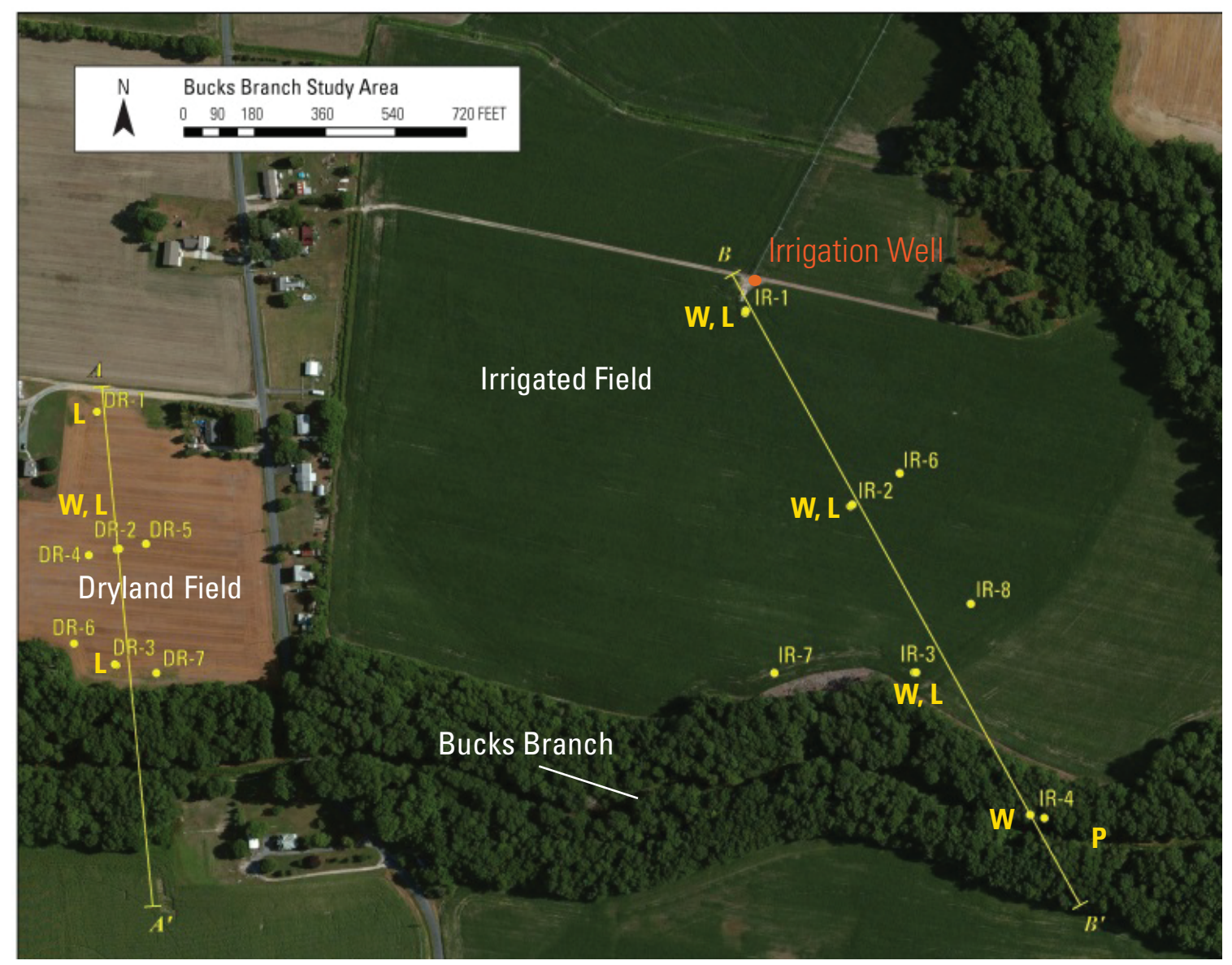

EXPLANATION

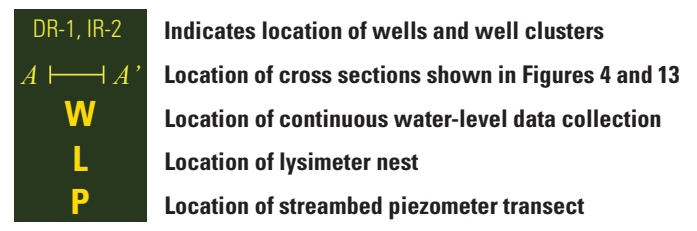

Figure 3. Location of groundwater flowpath networks, Bucks Branch study site, Sussex County, Delaware.

major ions by either the inductively coupled plasma method with atomic emission spectrometry, ion chromatography, or automated colorimetry. Nutrient analyses were performed by automated colorimetry (with persulfate digestion when required) with uncertainties of less than 10 percent (less than 20 percent for silica) (Ben Pressly, DNREC, written commun., 2012). Surface-water and soil-water samples for nutrients and major ions were analyzed in the DNREC laboratory using the same methods.

Samples collected for analysis of nitrogen isotopes were filtered onsite, first with a $0.45-\mu \mathrm{m}$ pore size filter and then through a nitrate-free $0.2-\mu \mathrm{m}$ filter. Samples were preserved with a potassium chloride tablet until shipment to the USGS Stable Isotope Laboratory in Reston, Virginia, where they were analyzed using the bacterial reduction method (Böhlke, 2002; Casciotti and others, 2002; Sigman and others, 2001).
Samples for determination of the apparent age of groundwater were collected once in each of the medium to deep wells. Samples from shallow wells screened near the surface of the aquifer could not be used for the determination of groundwater age because of the potential for mixing of groundwater with the atmosphere during sampling. Samples for age dating were processed, preserved, and shipped to the USGS Chlorofluorocarbon Laboratory in Reston, Virginia, and the apparent age of groundwater was determined from concentrations of dissolved atmospheric gases and gaseous sulfur hexafluoride $\left(\mathrm{SF}_{6}\right.$ ) using methods described in Busenburg and Plummer (2000). Dissolved gases (including nitrogen, argon, oxygen, carbon dioxide, and methane) are used to determine the recharge temperature of groundwater, which is used with $\mathrm{SF}_{6}$ to determine groundwater age. $\mathrm{SF}_{6}$ is soluble in groundwater, and the increasing rate of anthropogenic concentrations 
of $\mathrm{SF}_{6}$ has been well established for the atmosphere over time. Detectable amounts of $\mathrm{SF}_{6}$ are often present in younger waters (approximately 1970s), such as those in the surficial aquifer of Bucks Branch, and can be used for age dating. The apparent age of groundwater reflects atmospheric concentrations of $\mathrm{SF}_{6}$ at the time the water reached the water table. The nitrogen and argon ratio in dissolved-gas samples associated with age dating also was used to determine if denitrification had affected nitrate concentrations in groundwater as described in Böhlke and Denver (1995). When denitrification occurs, nitrogen gas is released and the ratio of dissolved argon to nitrogen in groundwater changes, indicating an excess in nitrogen gas compared to the natural ratio of nitrogen to argon gas in the sample.

\section{Soil Water}

Soil water was sampled using a network of suction lysimeters. Six sets of paired shallow (1-ft) and deep (3-ft) lysimeters were installed adjacent to well clusters in the flowpath network in each study field (fig. 3). Lysimeters were removed during planting and harvest and then reinstalled in each field. Samples from the shallow lysimeters represent water chemistry in the root zone, where it is plant-available, whereas samples collected from the deeper lysimeters represent water that has flowed to the base of the active plant root zone. Soil-water samples were collected year round after precipitation events greater than $0.75 \mathrm{in}$. over the study period to track the movement of water and chemicals through the soil zone.

Lysimeters, purchased commercially from Soil Moisture, Inc., were installed following the manufacturer's directions. Each lysimeter consists of 1.9-in.-diameter PVC tube, with a porous ceramic cup on the bottom sealed on the top by a rubber stopper. A 2-in. bucket auger was used to excavate holes to the appropriate depth for each lysimeter. Soils were removed into a bucket and mixed with deionized water to create slurry with the approximate consistency of cement mortar. A small volume of the slurry was poured down the hole and the lysimeter was pushed into the slurry leaving a 2 -in. section of lysimeter pipe protruding from the soil surface. A native soil slurry insured good contact between the soil surface and porous ceramic cup. The remaining soil was then back-filled into the hole, and firmly tamped down. The stopper assembly was protected from weather and animals by placing plastic bottles over the above-ground part of the lysimeter.

Prior to expected precipitation events greater than 0.75 in., a pistol-style hand pump was used to create a vacuum inside the samplers. The vacuum in the lysimeter pulled soil water through the porous ceramic cup where it was extracted for chemical analysis 1 day after the precipitation event. Sample recovery from lysimeters was quite variable - ranging from no sample volume to the maximum volumes of 949 milliliters $(\mathrm{mL})$ and 1,180 $\mathrm{mL}$ in 1- and 3-ft-deep lysimeters, respectively. Due to variable sample volumes, analytes were prioritized in the following order: specific conductance, nutrients, major ions, isotopes, and alkalinity. Laboratories and procedures used for sample analyses were the same as those used for groundwater-sample analysis.

Lysimeters were sampled after precipitation events through the duration of the study period, for a total of 19 sampling events and 110 total samples. Adequate sample volume was acquired to measure specific conductance in a total of 108 samples, nitrate and phosphorus in 89 samples, and major ions in 39 samples. Other analytes were measured less frequently.

An additional 15 lysimeters were installed near the existing lysimeters on the irrigated field to sample soil water during the cover-crop growing season of 2015. Additional lysimeter nests were sampled at 1-, 1.5-, and 3-ft depths, and split between rye and radish/rye cover-crop rows in the irrigated field. The irrigated field had two additional nests with 1- and 3 -ft depth lysimeters plus six 1.5 -ft lysimeters were added to existing nests. The dryland field, which was planted with a rye cover crop, received one additional lysimeter nest and three 1.5 -ft lysimeters were added to existing nests. The difference between fields was due to the larger size of the irrigated field and the variations in cover-crop planting. During the covercrop season, the irrigated field yielded 22 samples whereas the dryland field yielded only 2 samples.

\section{Surface Water}

A USGS streamflow station, 01487150, Bucks Branch near Atlanta, Delaware (referred to as site SW2), was installed to monitor flow and water quality. Streamgaging began in February 2014 and lasted through June 2016 (fig. 1). During the period of record, gage height was collected by use of a pressure transducer; discharge measurements were collected at base flow and during storm events. Gage heights were then used to develop a rating curve from which discharge could be predicted for all streamflow levels. Additional base-flow and stormflow discharge measurements were collected regularly to verify rating accuracy. All continuous stage and (computed) discharge data were collected and reviewed according to standard USGS procedures as outlined in Sauer and Turnipseed (2010).

Surface-water samples were collected upstream of the gage using a depth-integrated sampler and then composited in a churn following USGS protocols for equal-width-increment sampling (U.S. Geological Survey, variously dated). Field measurements of surface-water flow, $\mathrm{pH}$, specific conductance, dissolved oxygen, and temperature were collected at the time of sampling. Monthly samples of base flow and periodic samples of storms were collected for nutrients, major ions, and nitrogen isotopes at the gaged site. Samples for major ions and nutrients were analyzed at the DNREC Environmental Laboratory in Dover, Delaware, as described above for groundwater samples. Additional analyses for total nitrogen and total phosphorus were included in surface-water sampling. 
A total of 48 samples were collected at site SW2 for base flow and storms. Streamflow was measured and samples were collected synoptically at base flow at an additional nine surface-water sites located around the Bucks Branch watershed in the spring of 2014-15 and late winter of 2016 (fig. 1).

\section{Discrete Sample Quality Assurance}

The quality assurance of sampling included both replicates and blank samples for major ions and nutrients in groundwater and surface water. There was no significant variability or bias apparent in the sampling or laboratory techniques for these chemicals, with the exception of the last blank sample collected, which had a chloride detection of $34 \mathrm{mg} / \mathrm{L}$. No other chemicals were detected above reporting levels in that blank or in previous ones. Water samples collected on the same day as this blank had chloride concentrations lower than the blank and charge balances within 10 percent for positive and negative ions, so the data were deemed good to use with the measured chloride analyses.

After receiving field data and results from laboratories, graphical and statistical tests were used to describe the data and identify important patterns in soil-water chemistry; groundwater chemistry, recharge, and transport; and surfacewater flow and water chemistry. Data testing included relative abundance patterns, correlation matrices, linear correlations, and comparison of means. All data were reviewed and analyzed according to the Quality Assurance Project Plan submitted to DNREC and EPA.

\section{Real-Time Water Quality}

Water quality in the stream was monitored for temperature, specific conductance, $\mathrm{pH}$, and dissolved oxygen using a multi-parameter sonde starting in December 2014 and ending in August 2015. The monitor was co-located with the streamgaging equipment and deployed vertically near the center of flow. Continuous real-time data were collected every 15 minutes and transmitted every hour to the USGS National Water Information System website (data are accessible via NWIS for USGS site 01487150 at: https://waterdata. usgs.gov/de/nwis/). The monitor was checked for fouling and calibration regularly; at least one or two times a month, and if necessary, appropriate corrections were made to the data. The maintenance of water-quality monitors and data collection followed guidance in Wagner and others (2006). Low stream levels in Bucks Branch during some summer months prevented the collection of continuous water-quality data because the sensors had to be removed until water level increased enough to keep them covered. All continuous water-quality data were collected and reviewed according to standard USGS procedures as outlined in Wagner and others (2006).

\section{Soil Sampling}

Soil samples were collected before and after the main growing season on both irrigated and dryland fields of the intensive study site to a depth of $36 \mathrm{in}$. and subsequently analyzed for Total Kjeldahl Nitrogen (TKN). Values for TKN include the nitrogen held in organic and ammonium forms, and do not directly measure nitrate, however, TKN values are a good indicator of nutrient and organic matter in the soil profile. In fall 2014, one core was taken within a $20-\mathrm{ft}$ radius of each well. Sampling methods were expanded to ensure a more representative soil sample so that a composite sample was made by taking three cores within a $50-\mathrm{ft}$ radius of each well. Push probes were used to sample the top 2 in. of soil after scraping plant residue from the surface. A bucket auger was used to obtain a composite sample of the remaining profile, which was split into four vertical segments: $2-6$, 6-12, 12-24, and 24-36 in. Soil samples were air-dried within 4 hours of collection then ground and passed through a 2-millimeter sieve. Samples were submitted to the U.S. Department of Agriculture (U.S. Department of Agriculture Agricultural Research Service) (USDA ARS) Laboratory at University Park, Pennsylvania, for TKN analysis.

\section{Cover-Crop Soil and Plant Data}

Additional soil and plant samples were collected to study the effects of cover crops on soil chemistry and water quality. Cover-crop plants and soil samples were collected along an upland-to-lowland transect across the irrigated and dryland fields before and after radishes died in the winter. A 2.7-square-foot $\left(\mathrm{ft}^{2}\right)$ quadrat was thrown by hand 16 times in the larger irrigated field and 8 times in the smaller dryland field. All above ground plant material and radish tubers within the quadrat were removed and five 1-ft soil cores were collected with a push probe. Soil samples were air-dried within 4 hours of collection. Radish tubers were separated from foliage and freeze-dried separately to avoid rotting. Radish and rye greens were air-dried in ovens. All material was ground and sieved before analysis at the UD Soil Test Laboratory for nutrients and major ions.

\section{Data from Other Sources}

Data on soil moisture, irrigation timing and amounts, and local precipitation were acquired for the study site. Soil moisture data were collected by UD using matric potential sensors placed at 6-, 12- and 18-in. depths in both the dryland and irrigated fields. Data, which were provided by UD who maintained the equipment, were transmitted at 5-minute intervals by cell tower to the Irrometer Company web site for real-time access. Records of applied irrigation water were collected from the farmer. Rainfall and other meteorological parameters were downloaded from the DEOS station 
maintained at Bridgeville, Delaware (University of Delaware, 2017).

\section{Data Availability}

Groundwater, soil water, soil TKN, and plant data are available at [https://doi.org/10.5066/F77H1HK5 (Soroka and Denver, 2018)]. These data are not identified by specific location in order to maintain the privacy of the landowner. Continuous and discrete surface-water quality and flow data are available on the USGS National Water Information System (NWIS; U.S. Geological Survey National Water Information System, 2017) for the gaged site, USGS 01487150, and the synoptic surface-water sites (USGS 384112075370701; USGS 384132075380301; USGS 384211075383301; USGS 384132075383901; USGS 384203075395601; USGS 384236075395601; USGS 01487148; USGS 01487155; USGS 01487160; and USGS 384139075392001).

\section{The Water-Quality Response of Agricultural Conservation Practices at the Bucks Branch Study Site}

The intensive study site consists of two adjacent fields with long-term rotational cropping of corn, soybeans, and small grains. These are the most common crops in Sussex County, Delaware and most of the Delmarva Peninsula, and are largely produced to supply feed for the local poultry industry. Soil types and aquifer characteristics are the same in both fields. Irrigation began on the larger field in the study site ( 41.5 acres) in about 2000; the smaller field ( 9 acres) has not been irrigated. Both fields have been farmed using conservation tillage practices for over 15 years, which means that the soils are largely undisturbed between crops. Cover crops have been used on the dryland field after corn crops during several previous years and on the irrigated field for only 2 years after the corn crops during the study period.

\section{Hydrogeology}

The Bucks Branch study site is underlain by an 80 - to 90 -ft-thick surficial aquifer (fig. 4). Sediments consist mainly of orange to tan colored, fine to coarse sand and gravel with discontinuous layers of silt and clay. The land surface is relatively flat with only about a 5-10 ft change in elevation between the uplands to the streambank. The streambed in Bucks Branch is about $4 \mathrm{ft}$ lower than the adjacent streambank because of channelization to lower the water table and improve land drainage in the watershed. Rainfall at a nearby gage in Seaford, Delaware was 38.8 in. in 2014 and 43.1 in. in 2015, which is considered within the normal range for this region (Delaware Environmental Observing System, 2017).
The average annual recharge to the surficial aquifer in this area is about 14 inches per year (Sanford and others, 2012).

Groundwater flow is from the uplands towards the stream in both fields (fig. 4). Water levels were deepest beneath the uplands and ranged from about 8 to $12 \mathrm{ft}$ below land surface during the study period. The depth to water decreased downgradient toward the stream, where water levels ranged from about $4 \mathrm{ft}$ to $8 \mathrm{ft}$ below land surface beneath the edge of the dryland field, and less than $3 \mathrm{ft}$ to about $6 \mathrm{ft}$ below land surface beneath the edge of the irrigated field (fig. 4).

The vertical hydraulic gradient between the shallow and deeper wells was downward in upgradient parts of the flowpaths and upward near the stream (fig. 4). There was a strong upward hydraulic gradient near and beneath the stream indicating that Bucks Branch receives groundwater discharge from the entire thickness of the aquifer. The upward gradient was especially evident at site IR4, adjacent to the stream where water levels measured in the deepest well were almost $1.3 \mathrm{ft}$ shallower than in the two shallowest wells (fig. 4). An upward water-level gradient also was observed in a transect of temporary piezometers inserted into the streambed near site IR4 (see photograph). Water levels in the piezometers ranged from 15 to $18 \mathrm{in}$. above the streambed, and were also 4 to $9 \mathrm{in}$. above the stream surface.

Continuous water levels collected in four wells located in the flowpath of the irrigated field and one well in the center of the dryland field (fig. 3) show the effect of irrigation well pumping on water levels during the growing season (fig. $5 \mathrm{~A}$ ), and the effect of recharge to the water table during the winter (fig. $5 B$ ). The water-table elevation was similar in wells IR-1M near the irrigation well, and DR-2S on the adjacent dryland field, when the irrigation well was not functioning during the growing season or during the colder months (fig. 5).

During irrigation pumping, the water level-gradient was toward the irrigated well on the irrigated field; water levels rapidly recovered to near previous levels when the pumping

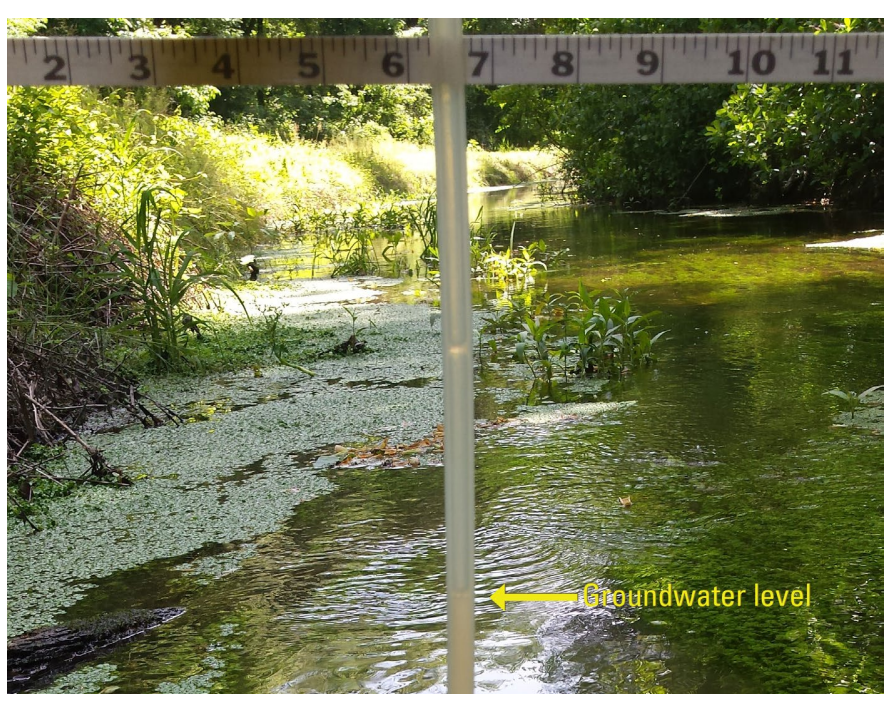

Water level in streambed piezometer shows upward gradient of groundwater discharge to surface water in Bucks Branch. Photograph by Alexander Soroka, U.S. Geological Survey 

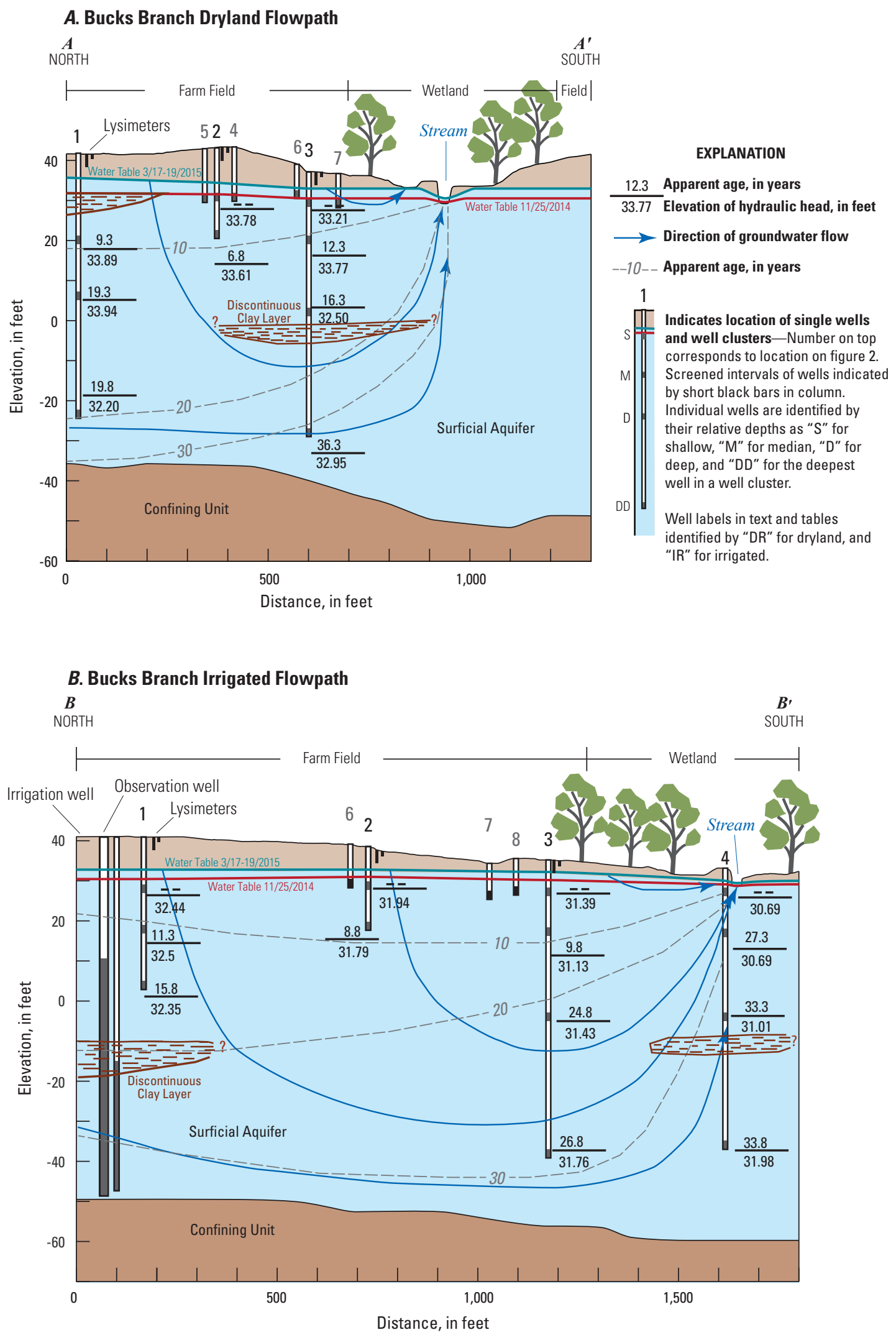

Figure 4. Groundwater flowpaths, the apparent age of groundwater, and the hydraulic-head gradients in flowpath wells beneath the $A$, dryland and $B$, irrigated fields Bucks branch study site, Sussex County, Delaware, April 2016. 

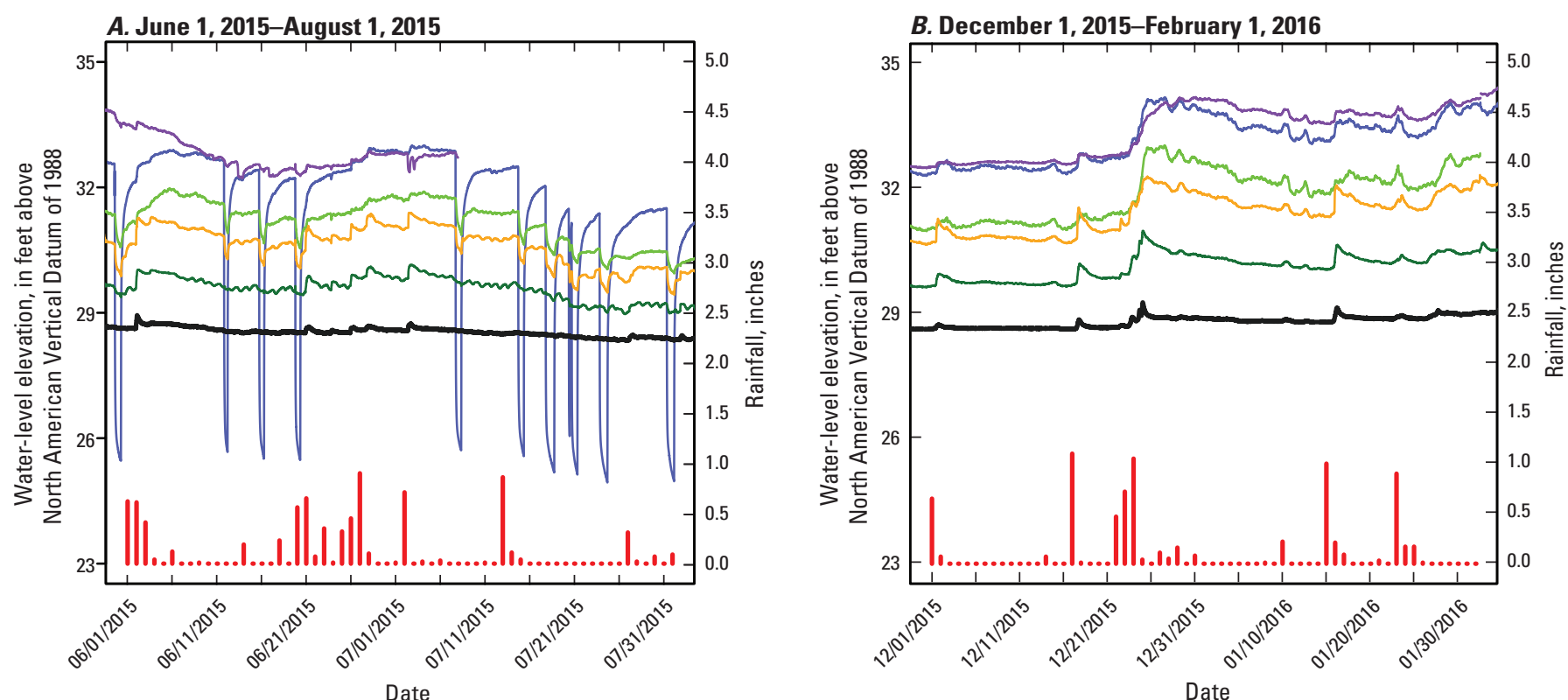

EXPLANATION

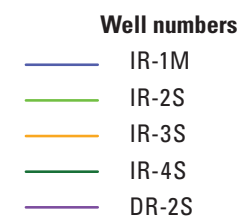

Rainfall data-Collected in Bridgeville, Delaware by the Delaware Environmental Observing System, University of Delaware (2017)

Bucks Branch streamgage SW2

Figure 5. Continuous monitoring of water-table and stream elevation on the irrigated and dryland fields; and rainfall in Bridgeville, Delaware showing $A$, the effects of irrigation during the growing season, and $B$, groundwater recharge during the winter, Bucks Branch Study site, Sussex County, Delaware.

stops (fig. 5A). Drawdown during irrigation near the irrigation well at IR-1M was about $7 \mathrm{ft}$. It was generally less than $1 \mathrm{ft}$ at IR-3S, located about $1,000 \mathrm{ft}$ away from the irrigation well towards the stream, and barely noticeable at IR-4S, adjacent to the stream (fig. 5A). Water levels collected at DR-2S, beneath the dryland field over 1,600 ft away from the irrigation well, also appear to be slightly affected by irrigation pumping, from both the adjacent study field and irrigation on the field immediately upgradient from the dryland field (fig. 5A). Bucks Branch did not show the effects of local irrigation pumping at the streamgage.

\section{Aquifer Recharge}

Most recharge to the water table occurs during colder months when evapotranspiration is least. During this time, continuous water-level records showed similar patterns in recharge occurrence after rainfall under both fields (fig. $5 B$ ). Recharge to the water table also was observed during the growing season in all wells at the study site. This pattern was especially evident in the continuous water-level record at IR-3S and IR-4S, where water levels were the closest to land surface of all monitored sites (fig. $5 A$ ). The water table ranged from 2.6 to $6.3 \mathrm{ft}$ below land surface at IR-3S, and from 1.3 to $4.3 \mathrm{ft}$ below land surface at IR-4S. The shallow water levels resulted in the potential for rapid transport of water through the soil zone during irrigation or precipitation events (fig. $5 A$ ). Increases in the water table during the growing season did occur, but were less frequent and showed a smaller increase in the water-table elevation at sites IR-1M, IR-2S, and DR-2S where the water table is deeper than at the sites with a shallower water table.

Soil moisture probes installed on both fields during the growing season to help guide irrigation timing were used for this study to compare amounts of plant-available water under irrigated and dryland conditions (fig. 6). These data also served as an indicator of potential soil conditions where recharge to the water table can occur. As soil moisture is depleted, soil tension increases (measured by centibars) and soils become dryer. A soil tension of 30 centibars in the sandy soils such as those in the Bucks Branch fields is considered to be a critical level for plant-available moisture and the level recommended for irrigation (James Adkins, University of Delaware Cooperative Extension, written commun., 2016) (fig. 6). Recharge to the water table occurred when soil moisture was high (soil tension was low) on both fields, but rainfall that occurred during or soon after irrigation increased the ability of water to move downward and recharge the aquifer. The difference in soil moisture between irrigated and dryland farming was especially evident in soil moisture values 

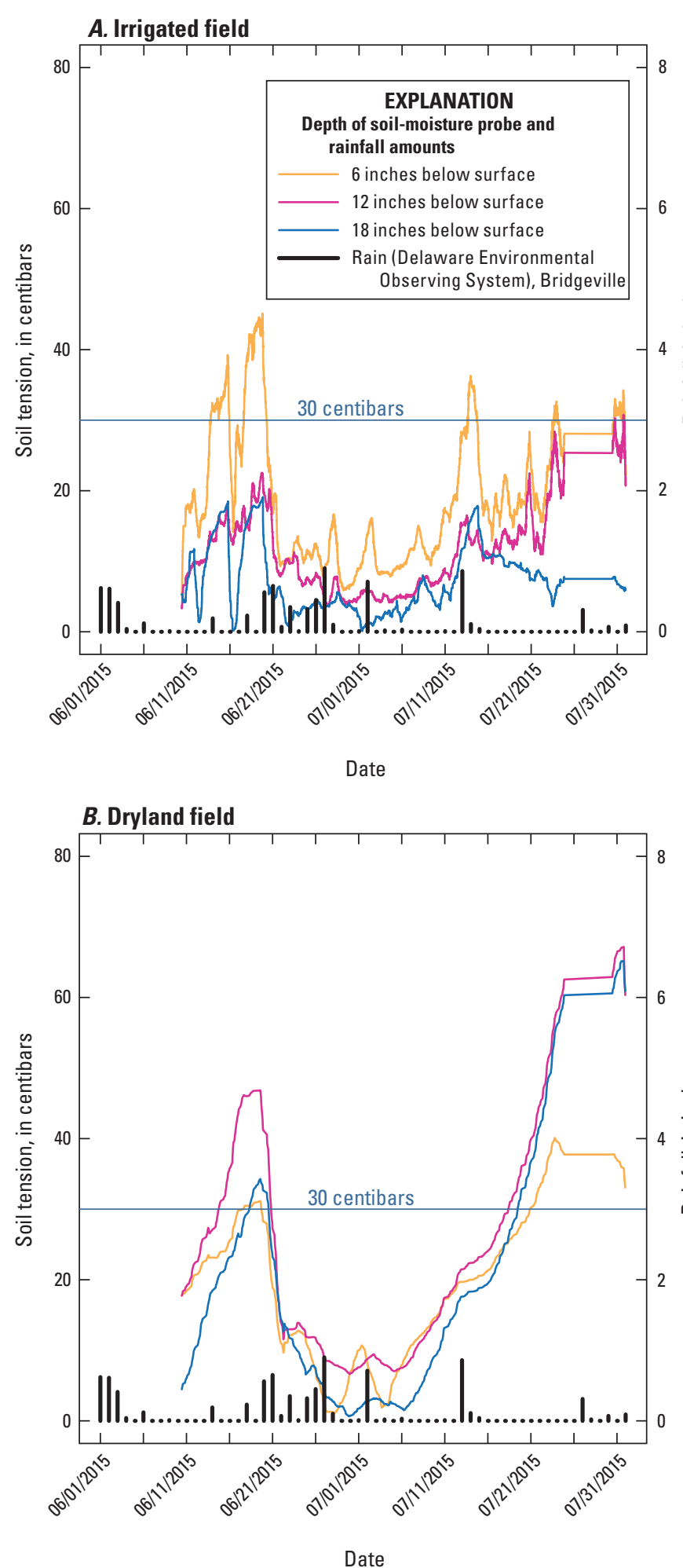

Figure 6. Comparison of soil moisture in the $A$, irrigated and $B$, dryland fields, Bucks Branch study site, Sussex County, Delaware, June and July 2015. recorded in the second half of July 2015 (fig. 6), when soil tension exceeded 30 centibars on the dryland field (fig. 5B) but soil moisture was maintained at a higher level under the irrigated field where irrigation was frequent (fig. $5 \mathrm{~A}$ ).

\section{Apparent Age of Groundwater}

The apparent age of groundwater at the study site ranged from about 6 years to over 37 years in samples from medium and deeper wells (fig. 4). Age dates could not be obtained from the shallowest wells because of the potential for introduction of air into the samples during pumping if the water table was drawn down to below the top of the well screens. Silica, which dissolves from aquifer material over time, correlated significantly with the apparent age of groundwater (fig. 7). This correlation was used to estimate the relative apparent age of groundwater from the shallow wells where age dating could not be determined directly. Although there is some variability in water with younger apparent ages, silica concentrations of less than $12 \mathrm{mg} / \mathrm{L}$ were estimated to represent water with an apparent age of less than 10 years.

\section{Soil Chemistry}

TKN is a measure of the total nitrogen in organic and ammonia forms that are available for plant growth in soils (U.S. Environmental Protection Agency, 1993). To determine concentrations and movement of the available nitrogen, TKN was measured before the growing season prior to nitrogen application and after crops were removed in fall 2014-15, and in spring 2016. The dryland and irrigated fields had similar mean concentrations of TKN, responses to seasonal

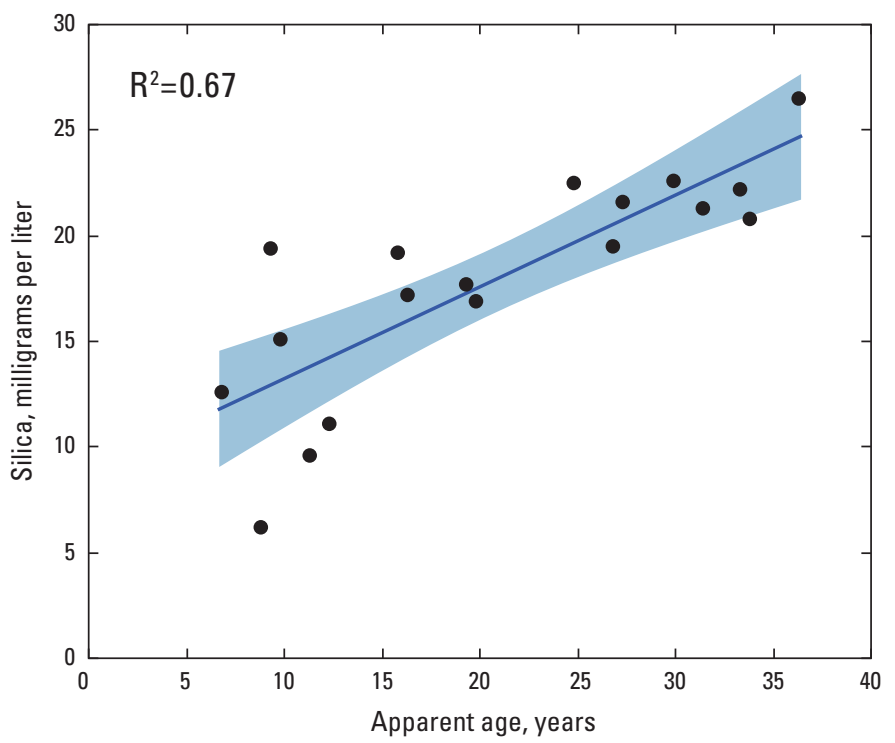

Figure 7. Comparison of silica concentrations to the apparent age of groundwater from flowpath wells, Bucks Branch study site, Sussex County, Delaware. 
changes, and TKN distribution in the soil profile and across the fields (table 2, fig. 8). The highest TKN concentrations were observed closest to ground surface and correspond to the historical plow layer and greatest biomass density (table 2). The top foot of soil on both fields held 1,900-2,000 pounds (lbs) of TKN per acre, several times what was observed in the 2- and 3-ft depths. TKN will be most effectively utilized by plant roots at shallow depths in the soil. Nitrogen, mostly in the form of nitrate, is available to leach to deeper depths in the soil and aquifer at the 3 -ft depth, as it has moved below the zone of most plant uptake.

Most leaching of nitrogen would be expected over the non-growing season when plant uptake is lowest and recharge is greatest. This would result in lower measured TKN during spring sampling times than during fall sampling times. Although some leaching was indicated between spring and fall sampling times on the irrigated field, in particular, where spring concentrations across the soil profile were lower than the preceding fall, this trend was not statistically significant $(p>0.05)$ (fig. 8A). TKN was higher in samples collected in 2015 than in 2014 in both fields (fig. 8A). The addition of manure to the fields for 2 years in a row may have contributed to the higher concentrations of TKN in 2015.

On both fields, upland sampling locations (field position 1 on fig. $8 B$; sites IR-1 and DR-1 on fig. 3) had higher TKN through the soil profile compared to lowland (field position 3 on fig. $8 B$; sites IR-3 and DR-3 on fig. 3) sampling locations. Lowland parts of the field were close to the forest edge, had the shallowest water table, and generally had wetter soils than upland areas. Greater wetness in the lowlands can result in greater potential nitrate loss through denitrification, mineralization, and leaching than in the dryer uplands of the fields and may account for this difference.

\section{Water Chemistry in Groundwater and Soils}

Samples from the temporary wells screened from near the water table to about $40 \mathrm{ft}$ below land surface were initially

Table 2. Mean Total Kjeldahl Nitrogen values for soils collected at various depths for the dryland and irrigated fields for all sampling locations at the Bucks Branch study site, Sussex County, Delaware.

[in., inches; mg/kg, milligrams per kilogram of dry soil; lb/acre, pounds per acre]

\begin{tabular}{cccccc}
\hline \multirow{2}{*}{$\begin{array}{c}\text { Depth, } \\
\text { in. }\end{array}$} & \multicolumn{2}{c}{ Dryland } & & \multicolumn{2}{c}{ Irrigation } \\
\cline { 2 - 3 } \cline { 5 - 6 } & $\mathbf{m g} / \mathbf{k g}$ & $\mathbf{l b} / \mathbf{a c r e}$ & & $\mathbf{m g} / \mathbf{k g}$ & lb/acre \\
\hline $0-2$ & 999 & 602 & & 1,049 & 632 \\
\hline $2-6$ & 609 & 734 & & 553 & 666 \\
\hline $6-12$ & 397 & 718 & & 364 & 658 \\
\hline $12-24$ & 186 & 672 & & 197 & 712 \\
\hline $24-36$ & 129 & 466 & & 118 & 427 \\
\hline
\end{tabular}

used to characterize groundwater quality at the Bucks Branch study site. Flowpath network wells and lysimeters were used to analyze the transport of nutrients, in particular nitrate, through soil and the surficial aquifer to the stream, and changes in groundwater quality over time.

\section{Characterization of Groundwater Quality Using Temporary Wells}

Groundwater beneath both fields at the Bucks Branch intensive study site was oxic, with dissolved oxygen concentrations between 3.4 and $10 \mathrm{mg} / \mathrm{L}$, and acidic, with $\mathrm{pH}$ ranging from 4.4 to 5.9 (table 3). Concentrations of nitrate and specific conductance were above those typically found under natural conditions $(0.4 \mathrm{mg} / \mathrm{L}$ as $\mathrm{N}$ for nitrate, and less than 60 microsiemens per centimeter at 25 degrees Celsius $\left({ }^{\circ} \mathrm{C}\right)$ for specific conductance; Denver and others, 2010) in all samples from both fields (table 3 ).

The median concentration of nitrate was $14.1 \mathrm{mg} / \mathrm{L}$ as $\mathrm{N}$ beneath the irrigated site and $12.4 \mathrm{mg} / \mathrm{L}$ as $\mathrm{N}$ beneath the dryland site in water from the temporary wells (fig. 9, table 3). Although the medians were similar, the range of nitrate concentrations was greater at the irrigated site (fig. 9A). Median specific conductance, a measure of the total ionic strength of water, and concentrations of calcium and chloride also were higher and had greater ranges at the irrigated site than at the dryland site (fig. 9A, table 3). These constituents were noticeably higher in younger water beneath the irrigated field compared to the dryland field, using increasing silica as an indicator of increases in the apparent age of water (fig. 9B).

Chemicals commonly associated with agricultural inputs; including calcium, magnesium, potassium, and chloride that are associated with the application of lime and potash to fields are positively correlated with specific conductance in groundwater from both study fields (table 4). This pattern is common on the Delmarva Peninsula, where natural water is very dilute and chemicals from fertilizer, manure, and lime applied to fields typically dominate water chemistry in agricultural areas (Denver, 1986; Hamilton and others, 1993). There are differences in the concentrations of some chemicals and the strength of correlation coefficients for these chemicals between the study fields, however. In addition to nitrate and specific conductance, chloride and calcium also had higher median concentrations beneath the irrigated field whereas the medians for potassium and sulfate were higher beneath the dryland field than the irrigated field (fig. 9A). It is not immediately obvious why these differences occur, but they may be related to differences in agricultural practices on these fields related to manure application, cover crops, and irrigation over time.

Agricultural effects on water quality seem to be greater in younger waters, rather than older waters, beneath both fields as seen in higher concentrations of many ions associated with agricultural chemical applications and specific conductance compared to the concentration of silica (fig. 9B). 

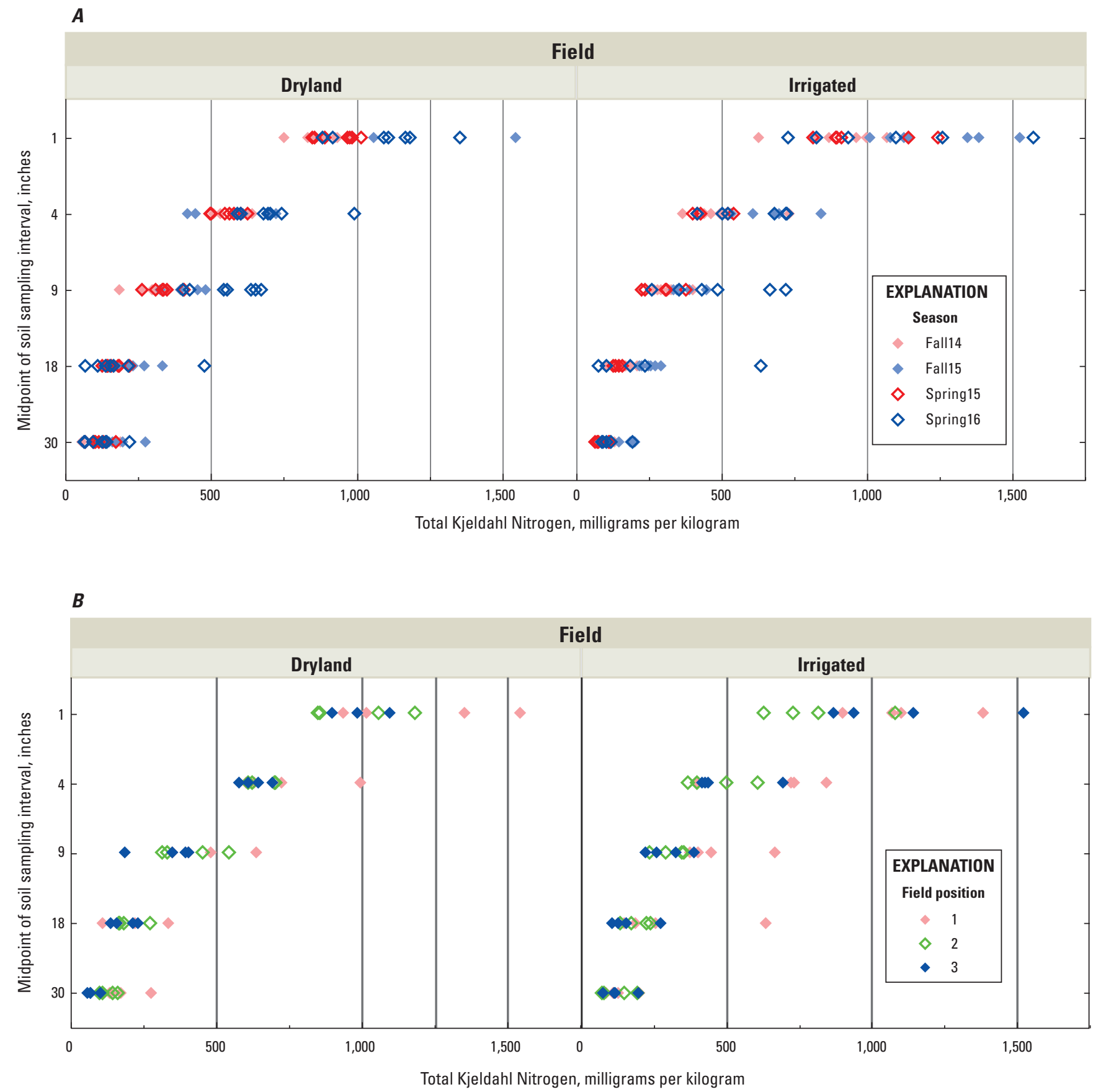

Figure 8. Total Kjeldahl Nitrogen values in soil for $A$, the mean concentrations in samples near all wells shown for different sampling times on the dryland and irrigated fields, and $B$, for the three main sampling locations on the dryland and irrigated fields in the flowpath networks, Bucks Branch study site, Sussex County, Delaware. [Well site locations shown on figure 3; field positions 1, 2, and 3 indicate locations from the field uplands by well site 1 to the field lowlands at well site 3 near the edge of both fields.] 
Table 3. Summary statistics for water samples from January and February 2014 in temporary wells installed on the study fields in the Bucks Branch study site, Sussex County, Delaware.

[n, number of samples; $\mathrm{ft}$, feet; ${ }^{\circ} \mathrm{C}$, degrees Celsius; $\mu \mathrm{S} / \mathrm{cm}$, microsiemens per centimeter at $25^{\circ} \mathrm{C} ; \mathrm{mg} / \mathrm{L}$, milligrams per liter; min, minimum; max, maximum]

\begin{tabular}{|c|c|c|}
\hline \multirow{2}{*}{ Constituent } & Dryland field ( $n=12$ ) & Irrigated field (n=15) \\
\hline & Median (min-max) & Median (min-max) \\
\hline \multicolumn{3}{|c|}{ Physical properties } \\
\hline Depth (ft) & $22.1(9.5-45.1)$ & $17.2(8.9-44)$ \\
\hline Water temperature $\left({ }^{\circ} \mathrm{C}\right)$ & $12(7.4-14.1)$ & $11.8(8.6-13.6)$ \\
\hline Specific conductance $\left(\mu \mathrm{S} / \mathrm{cm}\right.$ at $\left.25^{\circ} \mathrm{C}\right)$ & $181(100-281)$ & $221(113-324)$ \\
\hline Dissolved oxygen $(\mathrm{mg} / \mathrm{L})$ & $7(3.4-10.2)$ & $7.9(4.6-9.2)$ \\
\hline pH (standard units) & $5.2(4.4-5.9)$ & $5.1(4.7-5.9)$ \\
\hline \multicolumn{3}{|c|}{ Nutrients (mg/L) } \\
\hline Nitrate plus nitrite as nitrogen & $12.4(7.6-18.4)$ & $14.1(8.8-22.5)$ \\
\hline Ammonia & $0.07(0.02-0.14)$ & $0.06(0.04-0.30)$ \\
\hline Orthophosphate & $0.009(0.004-0.012)$ & $0.008(0.006-0.013)$ \\
\hline \multicolumn{3}{|c|}{ Major ions or elements (mg/L) } \\
\hline Calcium & $10.8(5.1-20.6)$ & $14.3(6.9-25.3)$ \\
\hline Magnesium & $5.2(3.8-9.2)$ & $5.4(2.5-9.9)$ \\
\hline Sodium & $2.3(1.6-6.3)$ & $4.8(2.9-7.6)$ \\
\hline Potassium & $8.9(2.5-23.4)$ & $4.6(1.9-12.2)$ \\
\hline Bicarbonate & $3.1(0.9-41)$ & $3.7(0.9-14.5)$ \\
\hline Chloride & $7(5-14)$ & $13(6-21)$ \\
\hline Sulfate & $16.9(1.5-29)$ & $11.2(0.8-16.5)$ \\
\hline Silica & $11.2(3.5-17)$ & $10.7(6.7-19.9)$ \\
\hline
\end{tabular}

Concentrations of silica below approximately $12 \mathrm{mg} / \mathrm{L}$ can be related to an apparent age of groundwater less than about 10 years. The greatest influence of agricultural chemicals at the Bucks Branch study site is seen in younger water beneath the irrigated field. Silica has a strong negative correlation with specific conductance, nitrate, calcium, potassium, and chloride beneath the irrigated field, indicating less agricultural influence in older groundwater (table 4). Results from the dryland field are similar, although concentrations of potassium are higher in younger water beneath the dryland field than beneath the irrigated field (fig. 9B). Overall, differences in groundwater chemistry indicate a greater degree of agricultural influence in water quality beneath the irrigated field, particularly in younger water, than the dryland field.

Concentrations of ammonia and orthophosphate were very low beneath both fields (table 3 ). Orthophosphate has a strong positive correlation with silica and a negative correlation with specific conductance; ammonia does not show a strong correlation with either compound (table 4). Both of these chemicals are not typically found at high concentrations in oxic groundwater (Denver and others, 2004). Phosphorus sorbs readily to particles in the soil and aquifer materials. Ammonia also is sorbed onto clay minerals and is less mobile than nitrate in groundwater. In addition, dissolved ammonia is readily converted to nitrate through the nitrification process in well-drained soils such as those found at this study site.

\section{Transport of Water and Chemicals from Soil to Groundwater}

Samples of water from the soil zone are useful for understanding nutrient transport to groundwater. Much of the nitrogen applied in ammonia and organic forms to welldrained sandy soils, such as those at the Bucks Branch study site, is converted to nitrate in the soil zone. Nitrate that is not used by plants is soluble and highly mobile, and can be carried by infiltrating water to the groundwater system. Although most phosphorus is sorbed in the soil zone, transport of dissolved phosphorus to groundwater, represented by orthophosphate, also can occur under anoxic conditions or when sorption sites on sediment particles are limited.

Specific conductance and concentrations of nitrate varied seasonally and with depth over time in the soil zone in samples from lysimeters from both study fields (fig. 10). The highest values were measured during the growing season shortly after fertilizer was applied to the fields. Concentrations 


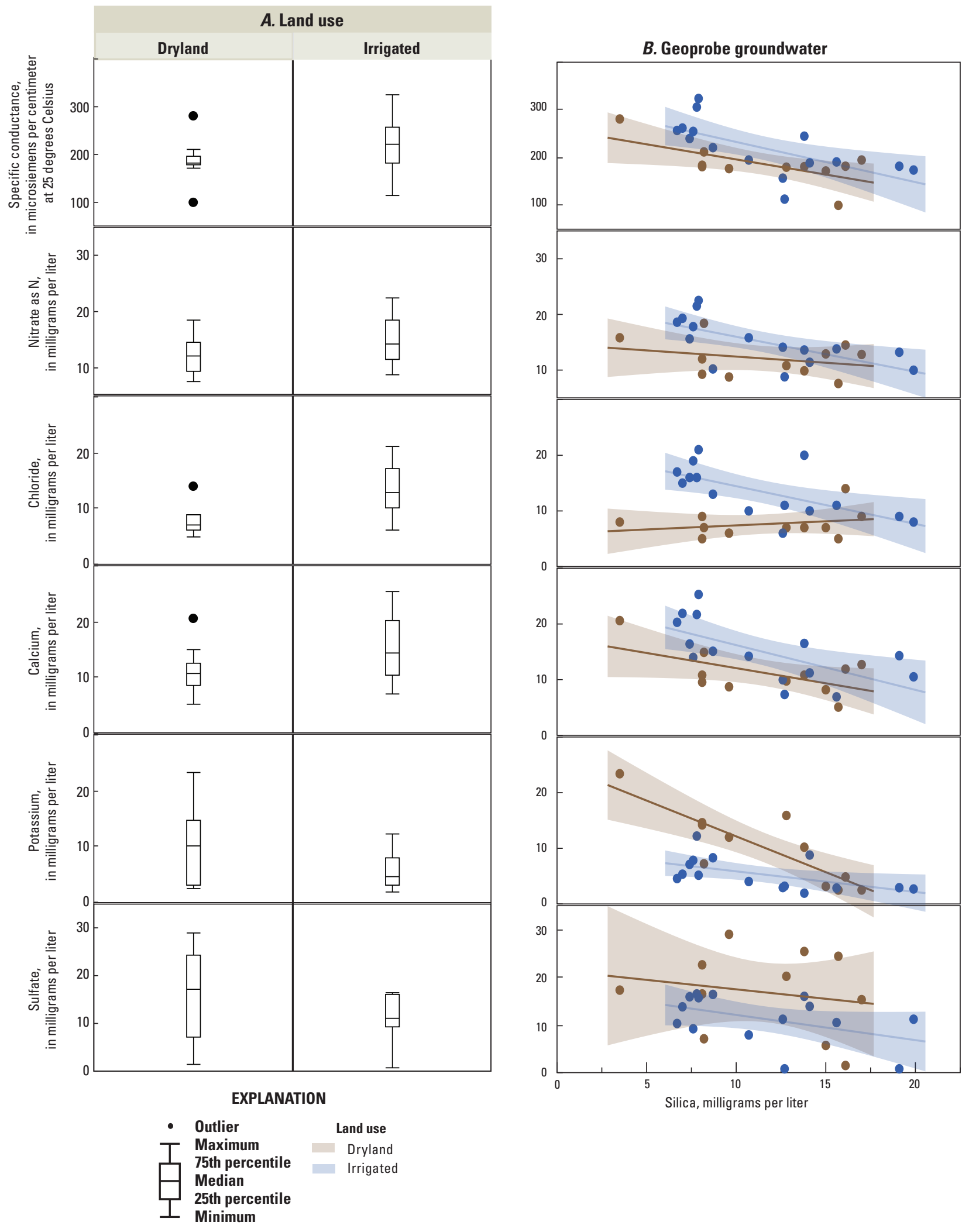

Figure 9. Summary of selected water-quality constituents from the temporary wells installed on the irrigated and dryland fields at the Bucks Branch study site: $A$, boxplots of selected constituents, and $B$, selected constituents compared to increasing age as indicated by increasing concentrations of silica. 
Table 4. Multivariate correlations of groundwater samples from the dryland and irrigated fields, Bucks Branch study site, Sussex County, Delaware.

$[0.99$, highlighted values indicate correlation coefficient is considered significant; positive coefficients are shown in black and negative coefficients are shown in red; --, not considered]

\begin{tabular}{|c|c|c|c|c|}
\hline \multirow{2}{*}{$\begin{array}{l}\text { Multivariate } \\
\text { correlations }\end{array}$} & \multicolumn{4}{|c|}{ Correlation coefficient } \\
\hline & \multicolumn{2}{|c|}{ Dryland } & \multicolumn{2}{|c|}{ Irrigated } \\
\hline Constituent & Silica & $\begin{array}{c}\text { Specific } \\
\text { conduc- } \\
\text { tance }\end{array}$ & Silica & $\begin{array}{c}\text { Specific } \\
\text { conduc- } \\
\text { tance }\end{array}$ \\
\hline Dissolved oxygen & 0.34 & -0.29 & -0.41 & 0.00 \\
\hline $\mathrm{pH}$ & 0.07 & 0.48 & 0.59 & -0.56 \\
\hline Specific conductance & -0.64 & -- & -0.65 & -- \\
\hline Orthophosphate & 0.99 & -0.57 & 0.95 & -0.57 \\
\hline Ammonia & 0.4 & 0.16 & -0.29 & 0.28 \\
\hline Nitrate & -0.3 & 0.69 & -0.66 & 0.86 \\
\hline Calcium & -0.61 & 0.93 & -0.65 & 0.9 \\
\hline Magnesium & -0.24 & 0.74 & -0.12 & 0.46 \\
\hline Sodium & 0.65 & 0.07 & 0.05 & 0.31 \\
\hline Potassium & -0.76 & 0.63 & -0.56 & 0.51 \\
\hline Bicarbonate & -0.35 & 0.64 & 0.8 & -0.58 \\
\hline Chloride & -0.11 & 0.24 & -0.64 & 0.82 \\
\hline Sulfate & -0.17 & -0.23 & -0.45 & 0.66 \\
\hline Silica & -- & -0.64 & -- & -0.65 \\
\hline
\end{tabular}

declined over time and were relatively low in soil water collected during the winter and early spring. Overall, 30 samples were collected from the dryland field lysimeters and 55 samples were collected from the irrigated field lysimeters, not including sampling for the cover-crop project at the end of the 2015 growing season. Sample recovery was greater beneath the irrigated field than the dryland field during the growing season, probably due to greater soil moisture and water movement as a result of irrigation (see fig. 6).

The highest nitrate concentrations in soil water beneath both fields were in samples from the 1-ft lysimeters (fig. 10B). Higher concentrations were measured in the deeper $3-\mathrm{ft}$ lysimeters later in the growing season, with concentrations sometimes higher at $3 \mathrm{ft}$, than at $1 \mathrm{ft}$ (figs. $10 A$ and $B$ ). Once water reaches the 3 -ft depth, it is essentially at the limit of the root zone and most nitrate in soil water is no longer taken up by plants and can be transported to groundwater. Nitrate concentrations in shallow groundwater (from wells less than or equal to $14 \mathrm{ft}$ below land surface) were similar to those in the 3-ft lysimeters during times when both were sampled (fig. 10B). Concentrations of nitrate and specific conductance were noticeably higher in the irrigated field soil-water samples than in the dryland field samples (figs. $10 A$ and $B$ ).

Orthophosphate was frequently detected in soil-water samples but concentrations were much lower in shallow groundwater (fig. 10C). Phosphorus readily sorbs onto soil and sediment particles where soils are well-drained, as they are in the Bucks Branch study site fields. Orthophosphate was detected more frequently in samples from the dryland field than in samples from the irrigated field, especially at the $3-\mathrm{ft}$ depth. Analysis of soils in these fields by UD found that soils beneath the dryland field had much higher concentrations of soil test phosphorus than soils from the irrigated field (Amy Shober, University of Delaware, written commun., 2016). Proximity to former poultry houses and past manure application, prior to implementation of nutrient management plans, may have led to higher phosphorus in the dryland field water samples.

As water moves from the soil zone into groundwater, the range in concentrations of nitrate and orthophosphate is dampened (fig. 11). Some of this pattern is related to the difference in the sampling interval between lysimeters and wells. The permeable tip of the lysimeters is only $2 \mathrm{in}$. long, so the sample represents only a small interval of soil water whereas the well screens pull water from a 3-ft interval of the aquifer, which integrates a larger vertical interval with potentially variable water quality within the aquifer. Concentrations of nitrate, referenced to $10 \mathrm{mg} / \mathrm{L}$ as $\mathrm{N}$ on figure 11, are less variable as groundwater moves into the aquifer, compared to water samples from the soil zone. Orthophosphate concentrations, referenced to $0.2 \mathrm{mg} / \mathrm{L}$, behave differently than nitrate as water moves from the soil to groundwater and are generally lower in groundwater than soil water because of the high degree of phosphorus sorption to soil and aquifer materials. As a result, concentrations of dissolved phosphorus in groundwater are typically well below the level of concern for surface water in Delaware $(0.2 \mathrm{mg} / \mathrm{L}$; Delaware Department of Natural Resources and Environmental Control, 2017), especially at deeper depths in the aquifer, making it unlikely that substantial phosphorus is contributed to surface water from upgradient groundwater sources (fig. 11B).

Specific conductance of soil water was strongly correlated with nitrate and other major ions associated with inputs of fertilizer and manure in soil-water samples from both study fields (table 5, fig. 12A). Nitrate, calcium, magnesium, and chloride had the strongest correlations (table 5). Trends in these chemicals were similar between the two study fields, although cation samples were analyzed less frequently because of variable amounts of water recovered, especially from samples collected during the growing season when plants are actively taking water from the soil zone (fig. 12A). Increasing concentrations of these chemicals with increasing specific conductance indicate a greater effect of agricultural chemicals on water quality. Differences in soil-water chemistry between the dryland and irrigated study fields are seen in the trends of orthophosphate, sulfate, and potassium. As mentioned previously, higher orthophosphate concentrations in the dryland samples than in the irrigated samples are probably related to previous manure application. It is not clear why trends in sulfate, sodium, and potassium are different between the two fields. 


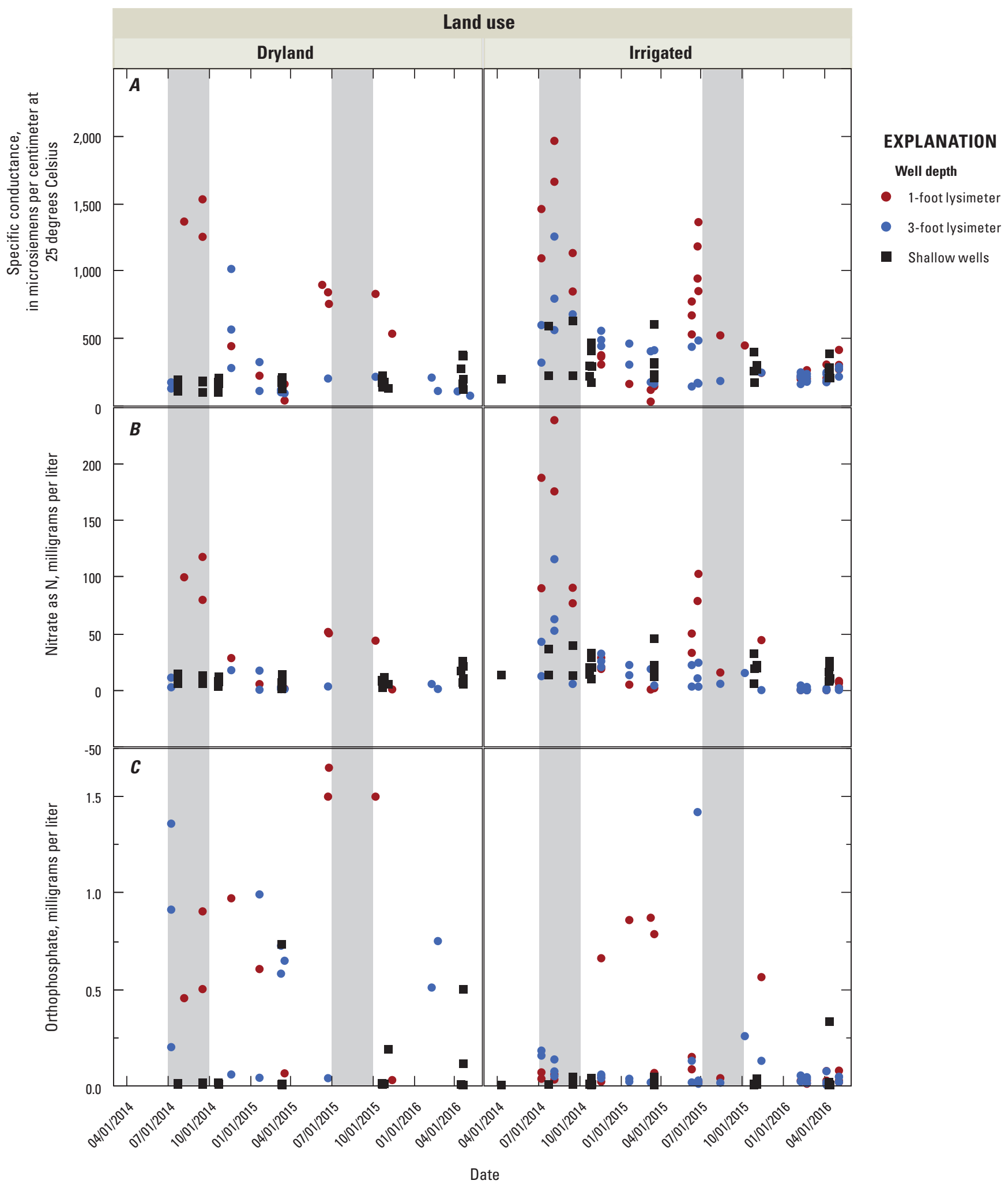

Figure 10. Samples of lysimeters and shallow groundwater showing trends over time in $A$, specific conductance, $B$, nitrate, and C, orthophosphate from the dryland and irrigated study fields, Bucks Branch study site, Sussex County, Delaware, 2014-15. [Gray bars indicate corn growing season.] 


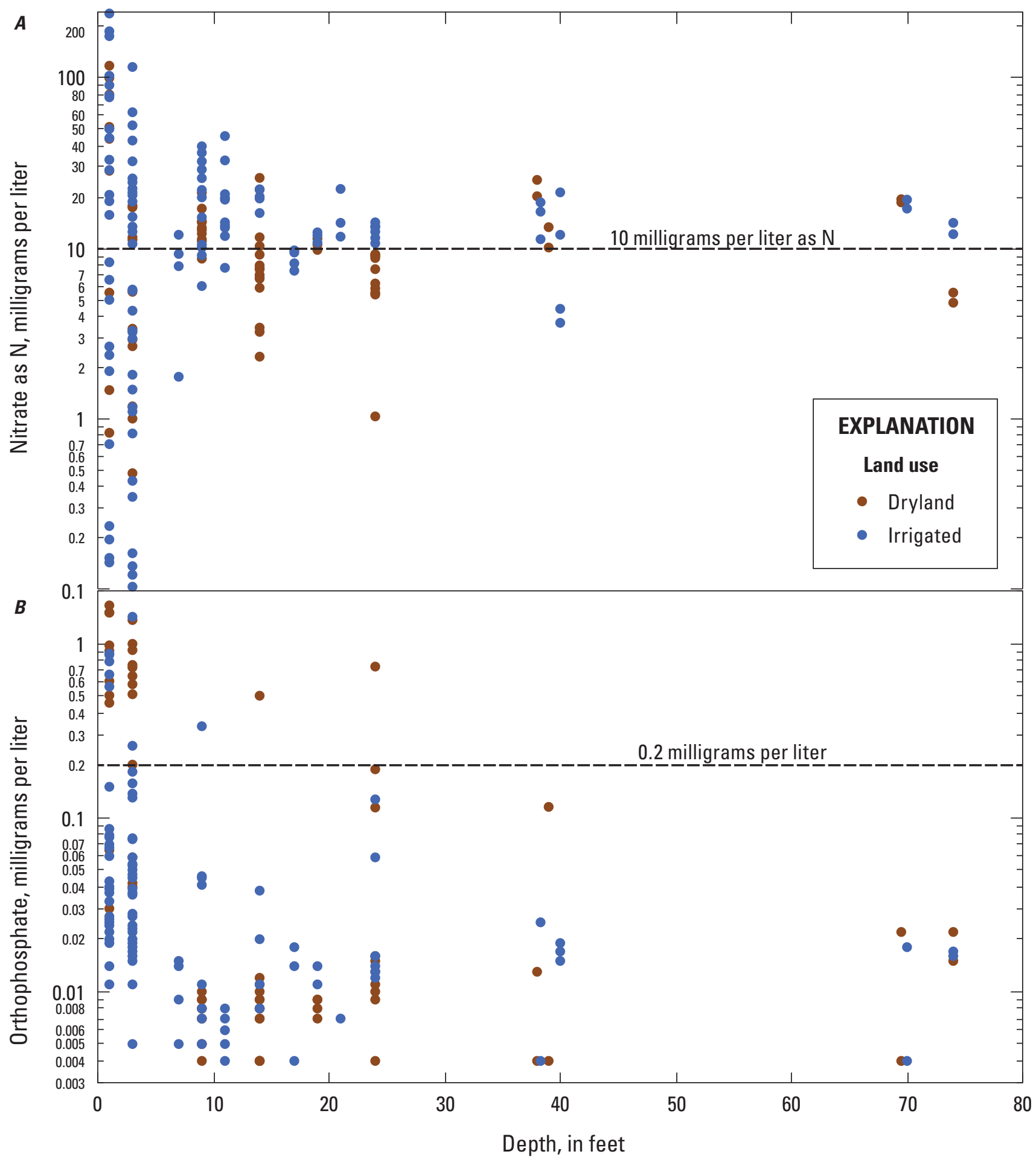

Figure 11. Comparison of concentrations of $A$, nitrate and $B$, orthophosphate to depth below land surface in lysimeters and wells from the Bucks Branch study site, Sussex County, Delaware. 
Table 5. Correlation between specific conductance, and nutrients and major ions in samples from lysimeters, Bucks Branch study site, Sussex County, Delaware.

[Correlation value of 0 indicates no relation, value of 1 (black) or -1 (red) indicates strong relation; -, negative; bold indicates strong correlation; black indicates positive correlation, red indicates negative correlation]

\begin{tabular}{llc}
\hline \multirow{2}{*}{ Parameter } & \multicolumn{1}{c}{ Dryland } & Irrigated \\
\cline { 2 - 3 } & \multicolumn{2}{c}{ Correlation value } \\
\hline $\mathrm{pH}$ & 0.01 & -0.45 \\
\hline Phosphate as phosphorus & 0.23 & -0.18 \\
\hline Nitrate and nitrite as nitrogen & $\mathbf{0 . 9 7}$ & $\mathbf{0 . 9 5}$ \\
\hline Ammonia & 0.19 & 0.19 \\
Calcium & $\mathbf{0 . 9 7}$ & $\mathbf{0 . 9 6}$ \\
\hline Magnesium & $\mathbf{0 . 9 7}$ & $\mathbf{0 . 9 7}$ \\
Sodium & $\mathbf{0 . 8 1}$ & $\mathbf{0 . 7 2}$ \\
Potassium & $\mathbf{0 . 5 5}$ & $\mathbf{0 . 5 1}$ \\
Chloride & $\mathbf{0 . 9}$ & $\mathbf{0 . 8 6}$ \\
Sulfate & $\mathbf{0 . 6 3}$ & 0.42 \\
\hline
\end{tabular}

\section{Transport of Nutrients through Groundwater to the Stream}

Factors affecting the transport of nutrients from groundwater to streams include the lag time between nutrients reaching the water table and their transport through groundwater, and also the potential for retention or loss in the soil zone or along flowpaths. The main processes that affect nutrient transport are the formation and loss of nitrate through nitrification and denitrification, and sorption or desorption of phosphorus onto sediment particles under oxic conditions (when dissolved oxygen is present) and anoxic conditions (when dissolved oxygen is absent).

Under oxic conditions, typical in the well-drained soils over much of the study site, nitrate is readily formed in the soil zone from ammonium that has been applied in commercial fertilizer formulations or after mineralization of organic nitrogen in manure. As long as dissolved oxygen is present, nitrate can move with water through the aquifer to the stream. If nitrate in soil or groundwater encounters anoxic conditions, nitrate can be lost from water through denitrification. This process often occurs in near-stream areas with poorly drained soils, such as riparian wetlands. In contrast, phosphorus is strongly sorbed onto soil particles in oxic environments and not readily transported through the soil zone to groundwater. As a result, there is very little transport of dissolved phosphorus in groundwater to streams, and most transport is overland. Once in streams, this sorbed phosphorus may be desorbed in streambed sediments, where anoxic conditions develop as vegetation degrades.

Concentrations of nitrate are widely variable but nitrate is present at all depths of the unconfined groundwater system beneath the irrigated and dryland fields (fig. 13, table 6). The maximum apparent age of groundwater measured in wells on the downgradient end of the flowpaths was from 33 to 36 years, which is well within the date range of higher nutrient application rates to agricultural land in this area (fig. 4; Ator and Denver, 2015). In most water samples with estimated apparent ages of less than 10 years, concentrations of nitrate were higher in shallow younger water than deeper older water, and higher beneath the irrigated field than beneath the dryland field (figs. $12 B$ and 14). Irrigation was reported to have begun 15 years prior to the study period. The highest concentrations of nitrate measured in groundwater were from wells IR-3S and IR-6S (table 6). These wells also had samples with the greatest range in concentrations, from less than 10 to over $40 \mathrm{mg} / \mathrm{L}$ as N. These patterns are probably related to a shallow water table and resulting fast recharge to groundwater near these wells, and differences in the chemistry of infiltrating groundwater over time.

\section{Isotopes of Nitrate and Denitrification in Groundwater}

The isotopic signature of nitrate can be affected by the mixing of water from different sources that have different isotopic signatures (Böhlke, 2002). Manure has been applied to the study fields along with commercial fertilizer for many years. Isotopes of nitrogen in nitrate generally have lower per mil values in commercial fertilizer and higher per mil values in manure (fig. 15). Most of the water samples have delta ${ }^{15} \mathrm{~N}$ values between 3 and 9 per mil, indicating a mixture of nitrogen from fertilizer and manure (fig. 15). The exceptions to this pattern are in samples from three wells in the dryland field (DR-1M, DR-1D, and DR-3D) that have values of delta ${ }^{15} \mathrm{~N}$ that resemble the values from fertilizer. Groundwater from these wells was likely recharged beneath the adjacent upgradient field that has not received manure as there is a discontinuous clay layer above well DR-1M that limits downward infiltration to the water table at that location (fig. 13A). Water in the deepest wells in the dryland flowpath site, DR-1DD and DR-3DD, also is likely to have originated in a recharge area upgradient of the study field (fig. 15).

Although most of the nitrogen isotopes of nitrate are similar in range between the dryland and irrigated fields, the oxygen isotopes of nitrate, delta ${ }^{18} \mathrm{O}$, are typically lower (less than 0 per mil) in water from the dryland field than from the irrigated field (fig. 15). Water samples from the irrigated field likely exhibit characteristics indicating mixing of water with a similar isotopic signature in nitrate as the dryland field, and nitrate from irrigation water that has a heavier $\operatorname{delta}^{18} \mathrm{O}$, but a similar range of delta ${ }^{15} \mathrm{~N}$ (fig. 15).

The presence of dissolved oxygen in all groundwater samples from the Bucks Branch study site indicates that denitrification is not a major process affecting nitrate concentrations in most groundwater samples (table 6). Denitrification typically occurs in poorly drained, organicrich soils or in older water where dissolved oxygen has been depleted. When denitrification occurs, the lighter isotopes 


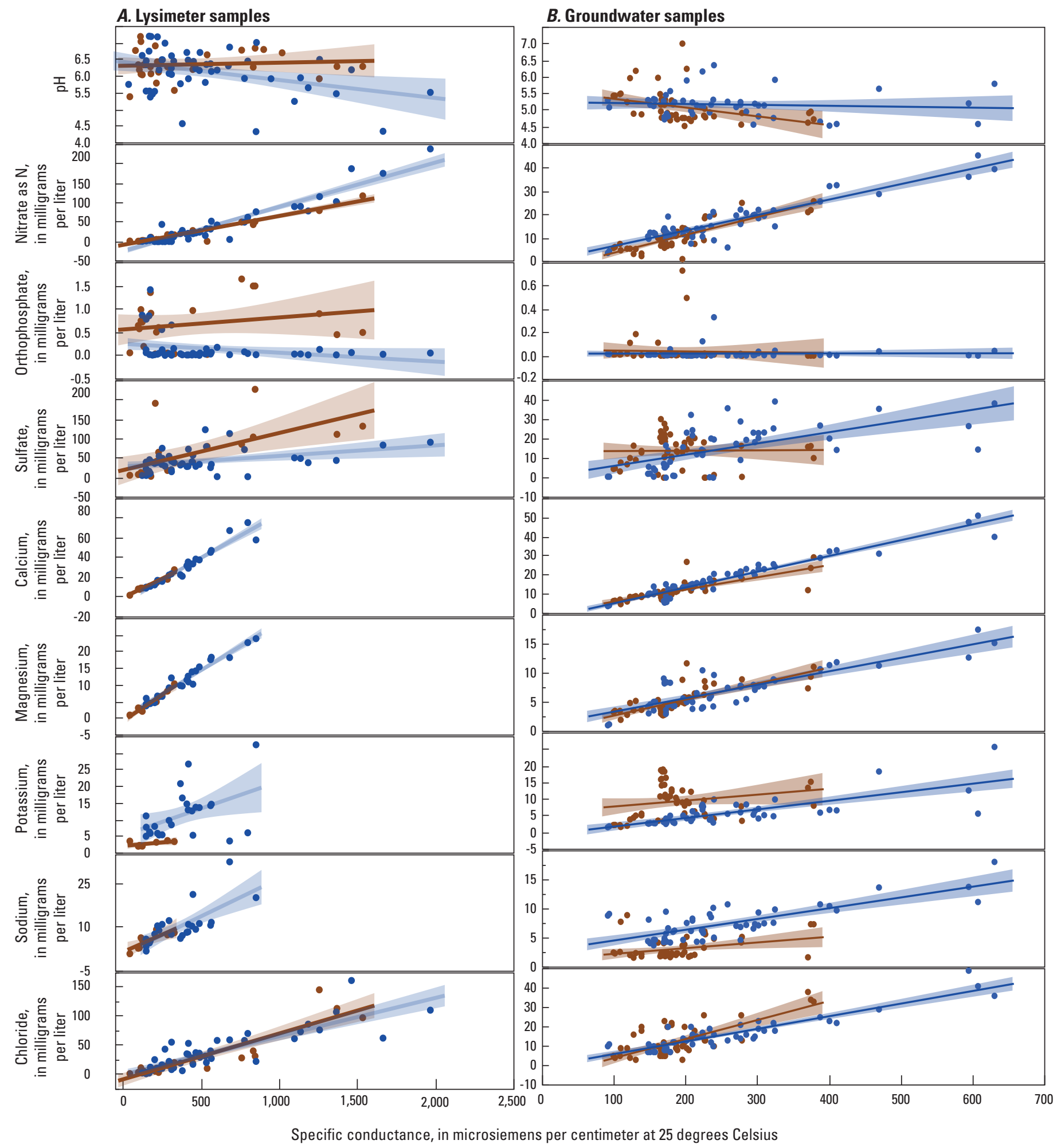

EXPLANATION

Figure 12. The relation between specific conductance and pH, nitrate, orthophosphate, sulfate, calcium, magnesium, potassium, sodium, and chloride in $A$, lysimeter samples, and $B$, groundwater samples from the dryland and irrigated fields, Bucks Branch study site, Sussex County, Delaware. 


\section{A. Bucks Branch Dryland Flowpath}

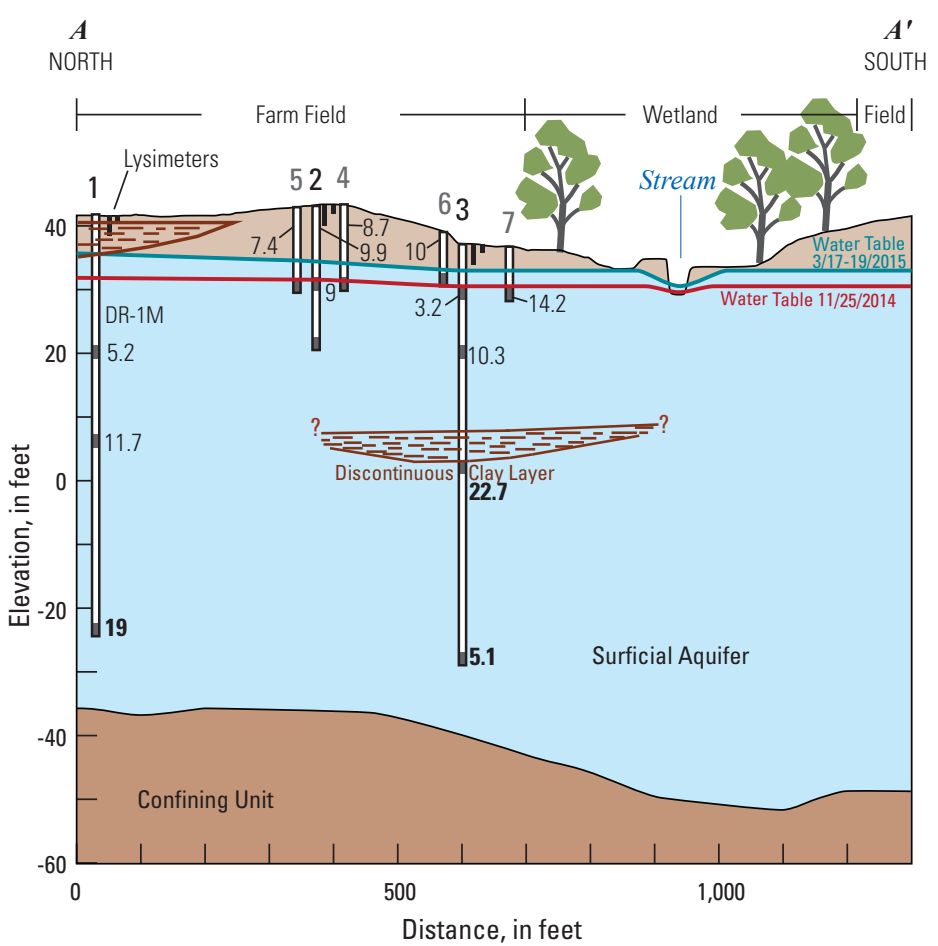

\section{EXPLANATION}

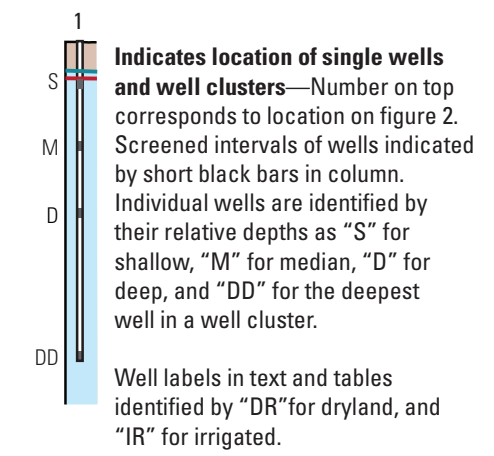

11.7, 22.7 Number indicates median nitrate concentration in groundwaterbold indicates partial denitrification of nitrate.

\section{B. Bucks Branch Irrigated Flowpath}

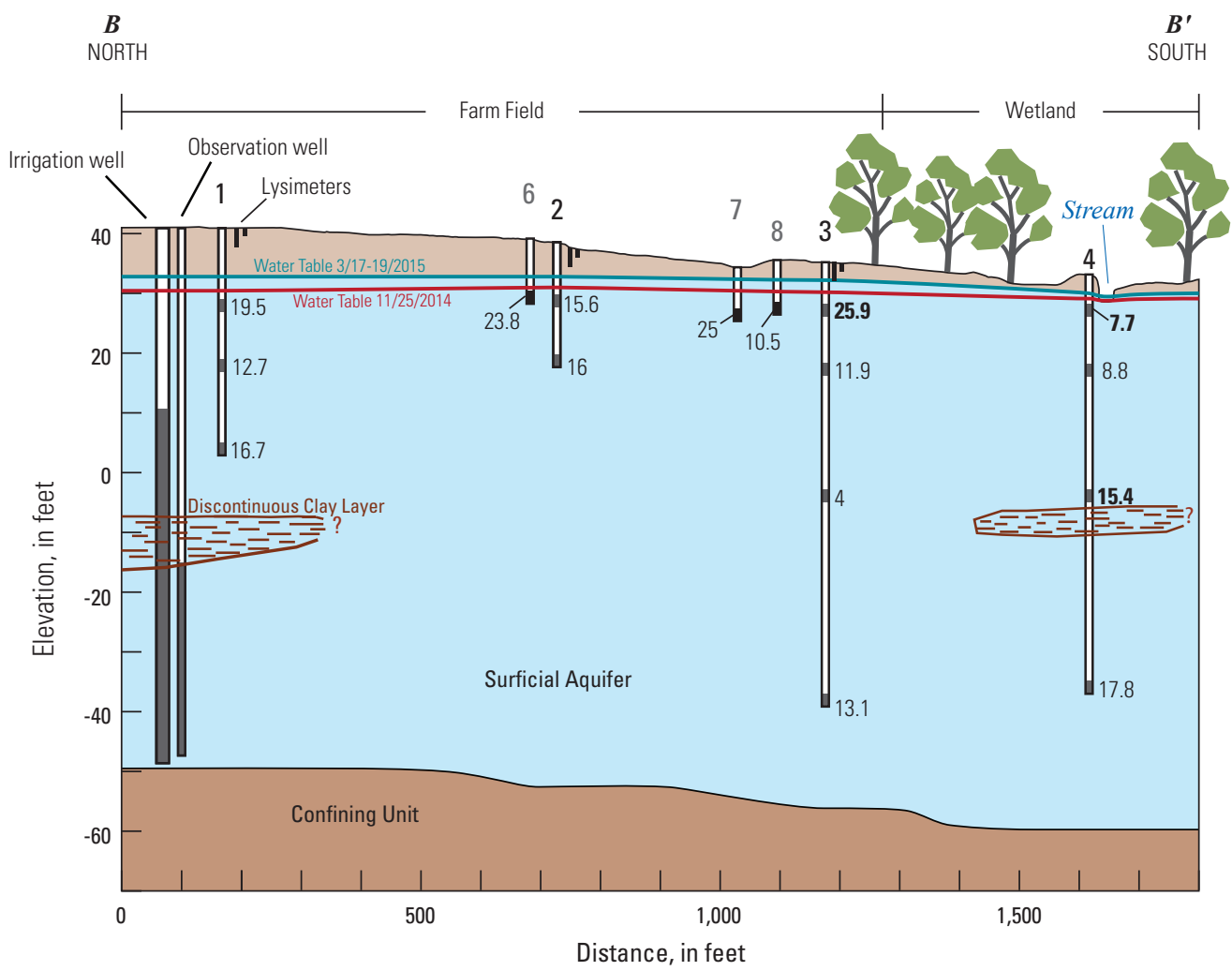

Figure 13. Median concentrations of nitrate in groundwater beneath $A$, the dryland and $B$, the irrigated fields of the Bucks Branch study site, Sussex County, Delaware. 
Table 6. Summary statistics for samples from flowpath wells, instream piezometers, and the intensive stream site (SW2), Bucks Branch study site, Sussex County, Delaware.

[n, number of samples; $\mathrm{ft}$, feet; $\mathrm{SC}$, specific conductance; $\mu \mathrm{S} / \mathrm{cm}$, microsiemens per centimeter at 25 degrees Celsius; ${ }^{\circ} \mathrm{C}$, degrees Celsius; DO, dissolved oxygen; $\mathrm{mg} / \mathrm{L}$, milligrams per liter; $\mathrm{NO}_{3}+\mathrm{NO}_{2}-\mathrm{N}$, Nitrate plus nitrite as nitrogen; $\mathrm{SiO}_{2}$, silica; bold, mean; min, minimum; max, maximum; DR, Dryland field; IR, irrigated field; -- no data. Sampling sites shown on figure 3.]

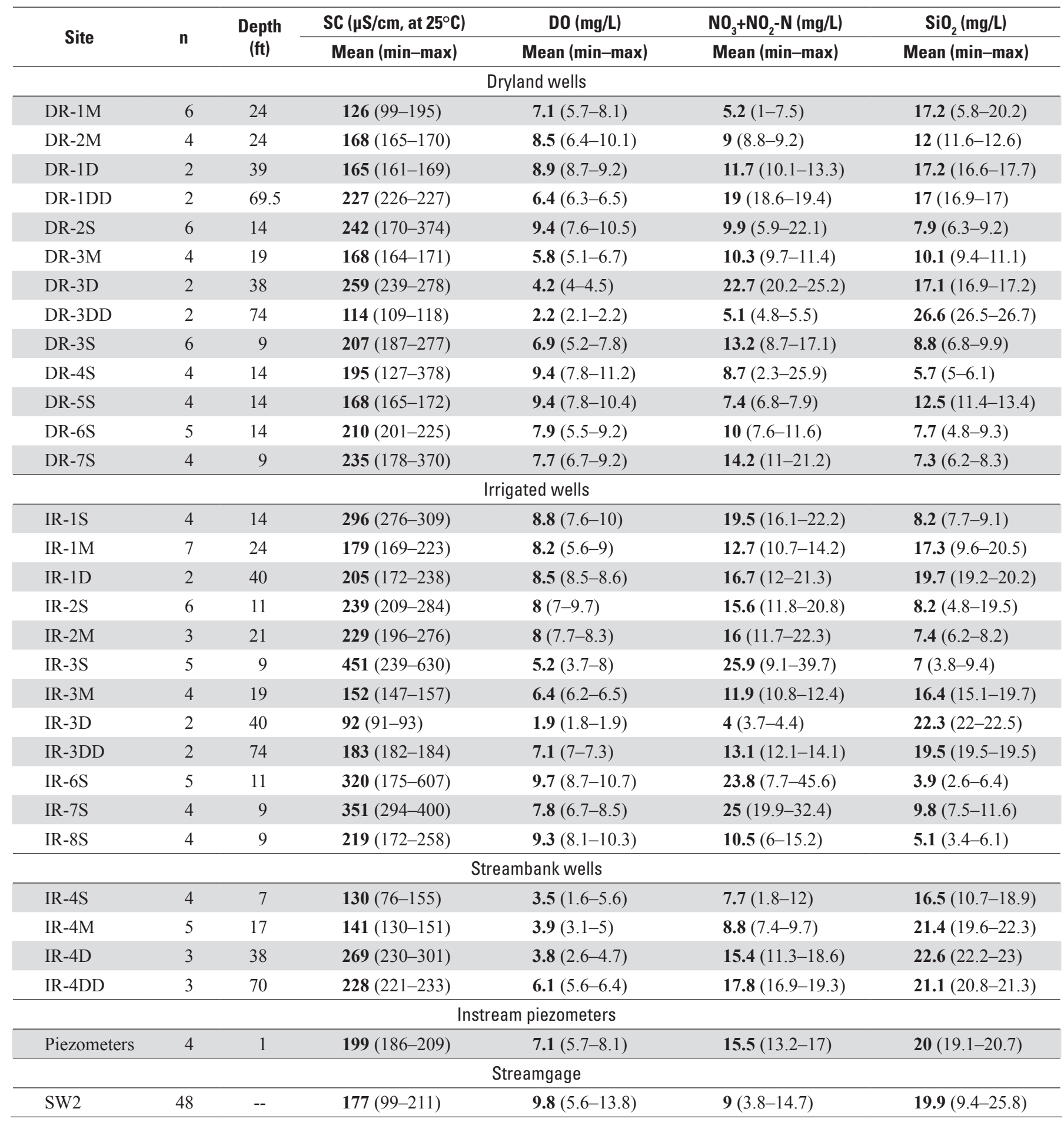




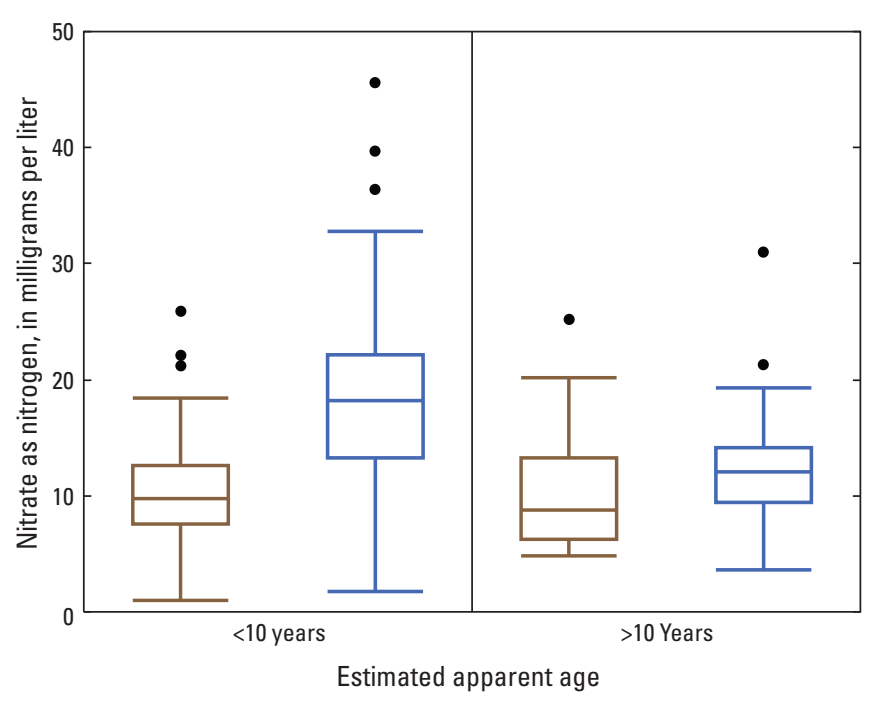

EXPLANATION

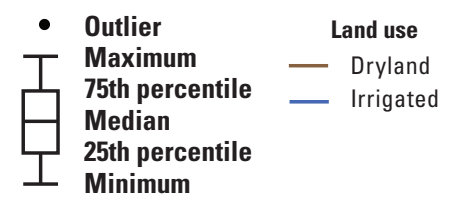

Figure 14. Concentration of nitrate as nitrogen in relation to the estimated apparent age of groundwater under the irrigated and dryland fields at the Bucks Branch study site, Sussex County, Delaware.

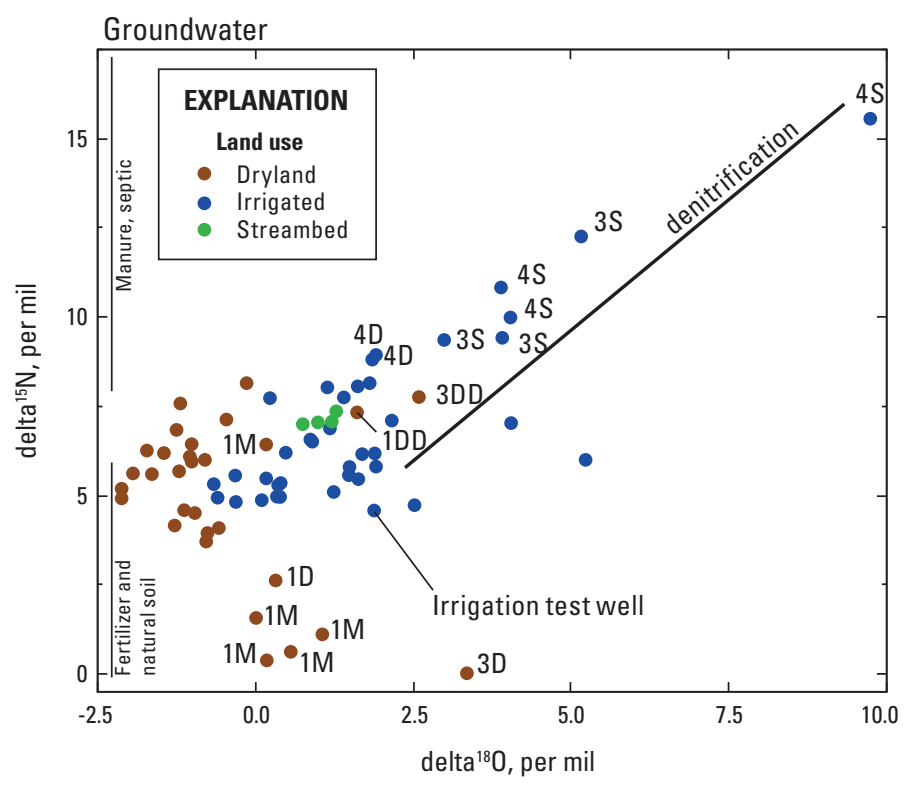

Figure 15. Ratios of the nitrogen (delta ${ }^{15} \mathrm{~N}$ ) and oxygen (delta ${ }^{18} \mathrm{O}$ ) isotopes of nitrate in groundwater from the Bucks Branch study site, Sussex County, Delaware. [Well numbers shown represent water samples that exhibit characteristics of denitrification. Specific well locations shown on figure 3.] of nitrogen $\left(\right.$ delta $\left.^{14} \mathrm{~N}\right)$ and oxygen $\left(\right.$ delta $\left.^{17} \mathrm{~N}\right)$ in nitrate are preferentially removed by bacterial reactions enriching water in the heavier isotopes, delta ${ }^{15} \mathrm{~N}$ and delta ${ }^{18} \mathrm{O}$, in the remaining nitrate (Böhlke, 2002). A trend of increasing delta ${ }^{15} \mathrm{~N}$ and delta ${ }^{18} \mathrm{O}$ away from the main clusters of samples from the irrigated and dryland fields is indicative of partial denitrification in some water samples (fig. 15). Although some degree of denitrification is indicated in samples from certain wells, nitrate is present in all samples and the water was not totally denitrified, in which case no dissolved oxygen or nitrate would be present (fig. 13).

Dissolved gases (including nitrogen, argon, oxygen, carbon dioxide, and methane) that were measured during age dating indicate that water samples from several wells near the downgradient edge of both fields and on the streambank show chemical evidence of denitrification in the form of excess nitrogen gas (IR-4D, DR-1DD, DR-3D, DR-3DD; fig. 13). The remainder of the wells sampled for age dating did not show evidence of denitrification in the dissolved-gas analyses.

Denitrification also is indicated by the ratios of delta ${ }^{15} \mathrm{~N}$ and delta ${ }^{18} \mathrm{O}$ in some shallow wells that did not have dissolved-gas analyses, most notably IR-4S and IR-3S, which are in a poorly drained part of the field near the riparian wetland (fig. 13). These wells were sampled multiple times over the study period. Water samples from these wells had similar isotopic ratios, but different isotopic values and a wide range in concentrations of nitrate in different samples (fig. 15, table 6). Conditions promoting denitrification are greater during periods of high water table when soil is saturated than when the water table is low and below the shallow wetland sediments, leading to varying degrees of nitrate loss over time. These wells and the other wells with water chemistry indicative of denitrification had dissolved oxygen concentrations that were generally lower (below $5 \mathrm{mg} / \mathrm{L}$ ) in some samples than those measured in the other wells at these sites (table 6).

A transect of four piezometers installed in the streambed near the irrigated field had similar isotopic ratios in nitrate as upgradient oxic groundwater (fig. 15). Dissolved oxygen was greater than $5 \mathrm{mg} / \mathrm{L}$ and nitrate ranged from $15-17 \mathrm{mg} / \mathrm{L}$ in the water samples, indicating nitrate in water discharging through the streambed was relatively unaltered by denitrification at this location (table 6). The apparent age of the instream piezometer samples was about 25 years, based on concentrations of dissolved silica (see fig. 7). This age is somewhat older than the estimated average age for surface water of 19 years in Bucks Branch at its downstream outlet (SW1, fig. 1), but surface water is a mixture of groundwater from flowpaths with many different ages (Clune and Denver, 2012).

\section{Surface-Water Flow and Chemistry}

The intensive surface-water site, where most stream data were collected for this project, was located on Bucks Branch at site SW2, upstream from the main watershed outlet at site SW1 (fig. 1). The watershed above SW2 drains about $3 \mathrm{mi}^{2}$ in 
the headwaters of the Bucks Branch watershed. Nitrate data from this site also were compared to nitrate data from samples collected at multiple sites around the watershed during spring base flow, and samples collected at the stream outlet collected by DNREC at SW1 (fig. 1). Base flow represents flow in the stream that has not been affected by runoff from recent storms.

\section{Streamflow}

Flow measured at the streamgage during base flow at Bucks Branch ranged from a high of about 10 cubic feet per second $\left(\mathrm{ft}^{3} / \mathrm{s}\right)$ during the winter and early spring to about $0.50 \mathrm{ft}^{3} / \mathrm{s}$ in the late summer; the highest stormflow during the study period was about $34 \mathrm{ft}^{3} / \mathrm{s}$ (fig. 16). Some stormflow discharges during periods of low base flow in the summer were actually lower than base-flow discharge during the colder months. Flow measurements could not be made at some times during the summer when flow was very low and impeded by rooted aquatic vegetation.

Direct runoff is relatively limited in this stream because of the flat topography of the surrounding uplands and the low topographic gradient, as well as the extensive riparian wetlands on both sides of the stream and an earthen ridge on one side that was created during channelization (fig. 3). Although runoff does affect streamflow in larger storms, about 93 percent of the flow in Bucks Branch at SW2 is estimated to be from groundwater discharge based on an estimate of base flow using the methods developed by Eckhardt (2005) (Jeff Raffensperger, USGS, written commun., 2017). Groundwater discharge from the entire thickness of the surficial aquifer provides flow to Bucks Branch. Inflowing groundwater was indicated by a strong upward hydraulic gradient in wells adjacent to Bucks Branch (fig. 4) and by instream piezometer measurements of hydraulic heads higher than the stream surface (fig. 3).

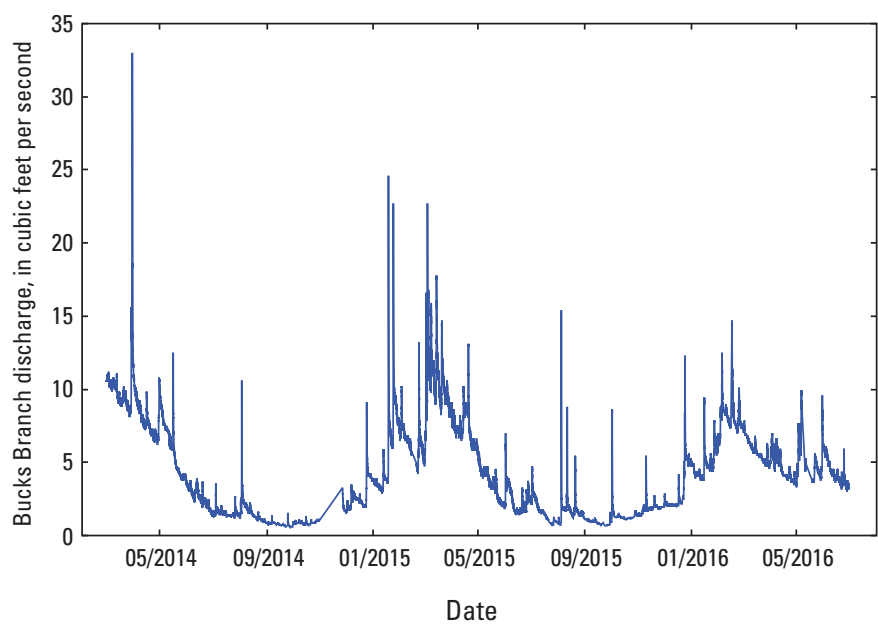

Figure 16. Streamflow at the gaged site SW2 during the study period, Bucks Branch study site, Sussex County, Delaware.

\section{Water Quality}

Nutrient concentrations in Bucks Branch result in large growths of aquatic plants and algae in the stream. The median concentration for total phosphorus, $0.025 \mathrm{mg} / \mathrm{L}$, measured during the study period at SW2, was lower than the State of Delaware target thresholds for phosphorus in fresh waters of $0.2 \mathrm{mg} / \mathrm{L}$ (Delaware Department of Natural Resources and Environmental Control, 2017). Total phosphorus concentrations exceeded the threshold in some high flows but were lower than the standard in about 90 percent of the samples collected for this study (fig. 17A). During base flow, when dissolved phosphorus is the major phosphorus species, the threshold was not exceeded. The median concentrations of total nitrogen $(9.0 \mathrm{mg} / \mathrm{L})$ at $\mathrm{SW} 2$ during the study period were significantly above the State of Delaware target threshold for nitrogen in fresh surface waters of $3.0 \mathrm{mg} / \mathrm{L}$, and among the highest measured in streams by DNREC (fig. 17B). The majority of this nitrogen is nitrate discharging from groundwater.

\section{Seasonal Trends in Surface-Water Quality}

Seasonal trends in water quality were seen in both continuous and discrete samples at SW2. These trends are related to changes in the relative proportions of groundwater and runoff, in-stream biological activity, and the water-table elevation that affects the interception and denitrification of groundwater in near-stream areas.

\section{Results from Continuous Monitoring}

Specific conductance generally decreases with increasing flow as runoff dilutes concentrations of ions in inflowing groundwater (figs. 16 and 18A). During some storms that occur during the beginning of the growing season, higher concentrations of particulate nitrogen and phosphorus and suspended sediment appear to cause an initial increase in specific conductance, followed by a decrease in specific conductance, as is typically seen in other storms throughout the year (fig. 18A). An increase in the potential for sediment transport when soils are being prepared for planting is the likely cause of this pattern.

Dissolved oxygen concentrations in surface water were consistently above State of Delaware standards of a minimum daily average of $5.5 \mathrm{mg} / \mathrm{L}$, or an instantaneous concentration of $4 \mathrm{mg} / \mathrm{L}$ in both continuous and discrete samples (fig. 18B; table 6) (Delaware Department of Natural Resources and Environmental Control, 2017). The continuous inflow of oxic groundwater helps to maintain dissolved oxygen concentrations in Bucks Branch in spite of the production and degradation of aquatic vegetation. Dissolved oxygen has daily diurnal variation throughout the year related to stream-community respiration. As temperature and light increased in the spring, this daily variation exceeded $8 \mathrm{mg} / \mathrm{L}$ (fig. 18B). The largest variations occurred coincident with blooms of floating aquatic plants such as duckweed and filamentous algae. Rooted 

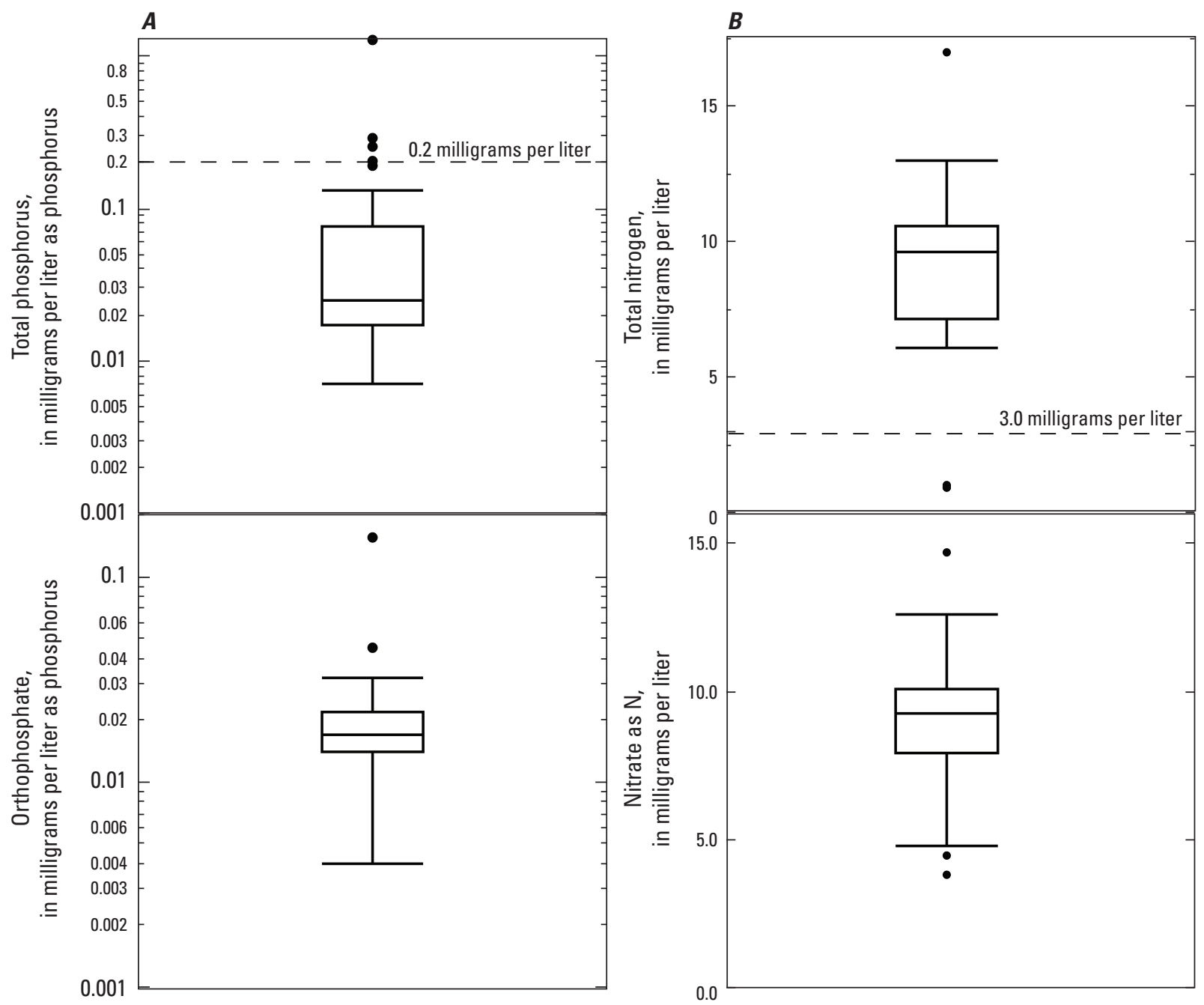

\section{EXPLANATION}

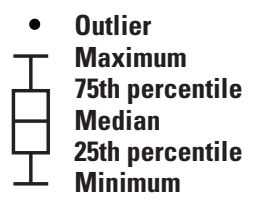

Figure 17. Concentrations of $A$, phosphorus and $B$, nitrogen in surface water, site SW2, Bucks Branch study site, Sussex County, Delaware.

vegetation was observed to dominate instream plants over the remainder of the year, and the diurnal fluctuation was lower.

Water temperature and $\mathrm{pH}$ also followed seasonal patterns (figs. $18 C$ and $D$ ). Water temperature ranged from near freezing to almost $25^{\circ} \mathrm{C}$ during the period with continuous monitoring. Although water temperature was closely related to air temperature, because of continuous groundwater discharge with a mean temperature of about $15^{\circ} \mathrm{C}$, stream water rarely froze. The $\mathrm{pH}$ of water ranged between 6 and 7 and fluctuated daily. The largest fluctuations were during the time of greatest instream respiration and diurnal fluctuations in dissolved oxygen. Otherwise, $\mathrm{pH}$ increased with temperature during the summer months.

\section{Monthly and Storm Data}

The major-ion chemistry of surface water in Bucks Branch closely resembles that of groundwater, as would be expected in a stream with over 90 percent of its flow from groundwater discharge. Specific conductance, $\mathrm{pH}$, and the major elements contributed by groundwater in predominantly agricultural areas, including nitrate, calcium, and magnesium are higher during base flow than stormflow, and highest when base flow is lowest and there is little discharge from nearstream wetlands (fig. 19). Concentrations of silica, which is derived from the dissolution of silicate minerals in soil and aquifer sediments, also are inversely related to flow (fig. 19). 

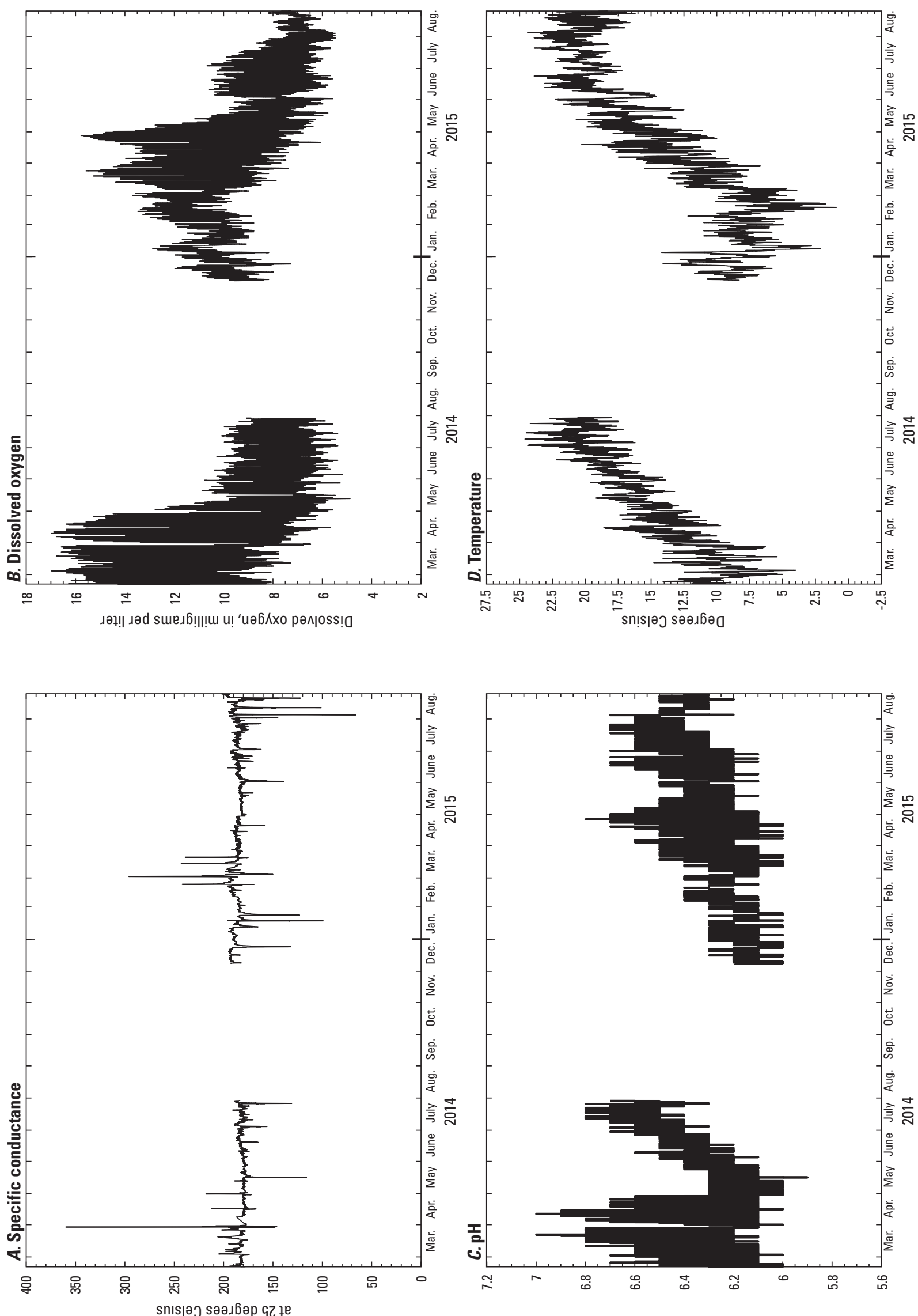

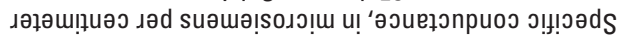

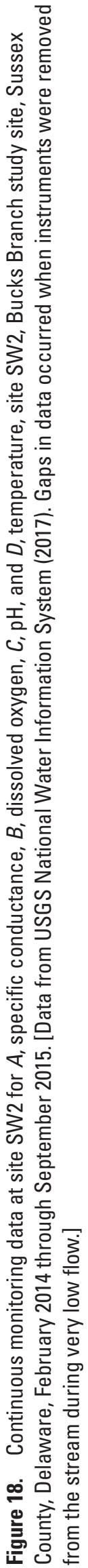




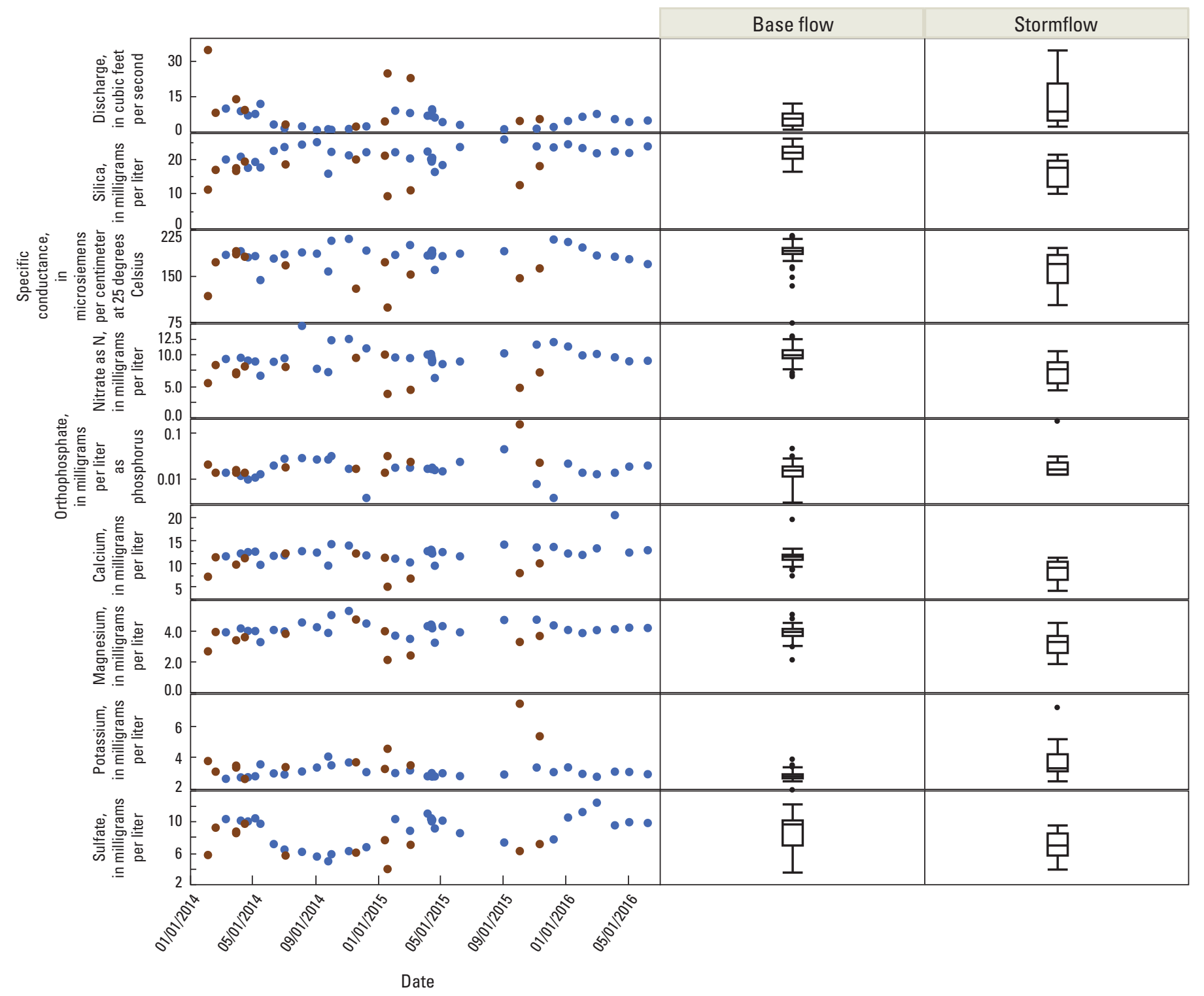

EXPLANATION

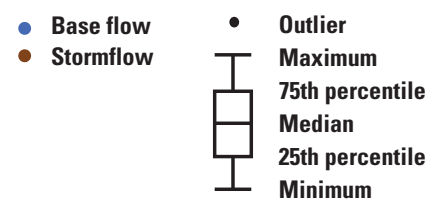

Figure 19. Concentrations of selected constituents over time in base flow and stormflow, site SW2, Bucks Branch study site, Sussex County, Delaware. 
In addition, silica was highest during the lowest base flows in the late summer, indicating a higher proportion of older water entering the stream from agricultural uplands when the water table was low and shallow near-stream wetland sediments were dry. Specific conductance, nitrate, calcium, and magnesium were also highest when base flow was lowest. When base flow was higher in the winter and spring, the near-stream wetland contribution to streamflow increased and diluted the effects of agricultural chemicals. Sulfate concentrations were higher when base flow was higher, corresponding to periods when groundwater was discharging from the riparian wetlands (fig. 19).

Concentrations of nitrate in stream water at the same flow rate are lower during the spring and summer months when plant uptake and respiration are greatest than in the colder fall and winter months (fig. 20). Diurnal samples for nitrate in surface water collected for 2 days when fluctuations of dissolved oxygen were greatest in April 2015 showed a decrease of about $1 \mathrm{mg} / \mathrm{L}$ as $\mathrm{N}$ from the dissolved oxygen low prior to sunrise, and the high at about noon at site SW2. Total phosphorus is sometimes higher during stormflow, although the low potential for overland transport at this site limits phosphorus movement. Potassium, which is associated with agricultural inputs, also increases during stormflow in Bucks Branch (fig. 19). This increase is likely related to the release and resuspension of potassium, which is a major component of plants, from degradation of instream plant material (Brady and Weil, 2008), or potassium carried in runoff from local fields.

The loss of nitrate through denitrifcation is indicated by an increasing trend in the ratio of nitrate and oxygen isotopes of nitrate in surface water (fig. 21A). Surface-water samples

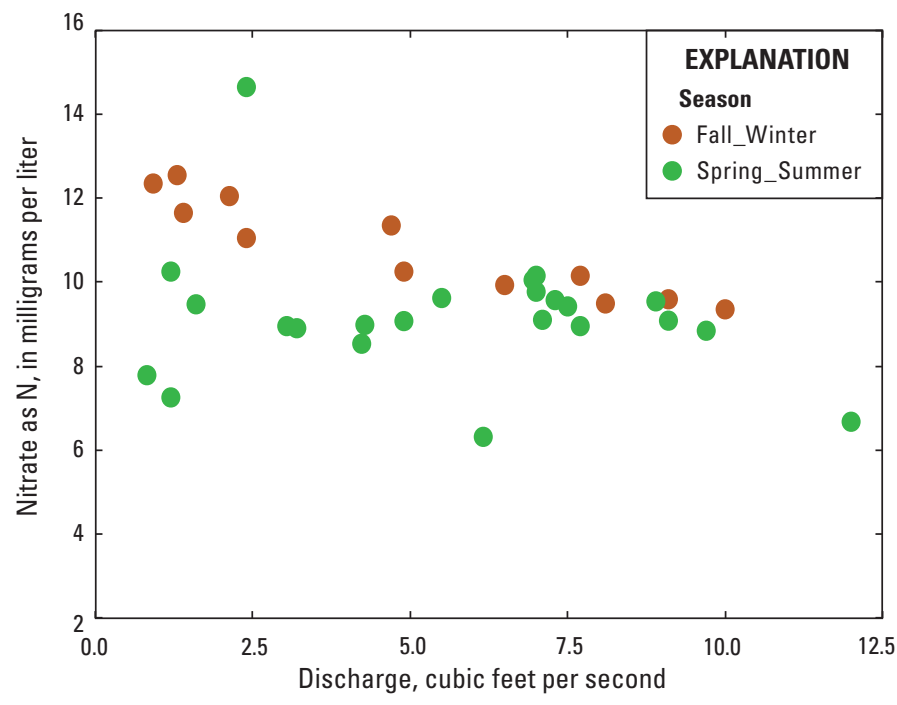

Figure 20. Differences in the concentrations of nitrate in base flow at similar flow rates during the fall through winter and spring through summer, site SW2, Bucks Branch study site, Sussex County, Delaware. had a relatively consistent ratio in the nitrogen and oxygen isotopes of nitrate; some samples in the spring and summer were more enriched (higher per mil values) and some samples from the fall and winter showed lower enrichment (fig. 21A). If the sources of nitrate to surface water remain the same, which is assumed in Bucks Branch, samples with higher per mil values indicate a greater degree of denitrification. The potential for greater denitrification is supported by a decrease in nitrate concentration with increasing isotope values in the spring and summer (fig. 21B). Nitrate concentration is diluted during stormflow compared to base flow in the fall and winter. Nitrate concentrations are highest in the stream during fall and winter base flow (figs. 20 and 21).

\section{Effect of Groundwater on Surface Water in the Bucks Branch Watershed}

Agricultural land, primarily cultivated land, but also land including concentrated animal feeding operations, covers about 67 percent of the land surface in the watershed above site SW2 and, as such, is the major source of nitrate to the stream (fig. 1). Most of this nitrate comes from discharging groundwater. Other land uses, including combined forest and wetland (about 29 percent), and residential land (about 5 percent) also contribute groundwater to the stream and affect overall stream-water quality. Nitrate can be lost from discharging groundwater that flows through poorly drained sediments with anoxic conditions in wetlands associated with the forested riparian zone.

\section{Estimated Nitrate Loss to Bucks Branch Through Denitrification}

The total amount of nitrate potentially contributed to the stream from groundwater (total $N$ ) and the loss of nitrate through denitrification in near-stream areas (Nloss) was estimated during periods of higher base flow using a simple mixing model. The model estimates potential nitrate loadings from different proportions of three major land uses in the watershed, and is compared to the median instream nitrate concentrations of $9 \mathrm{mg} / \mathrm{L}$ as $\mathrm{N}$ to determine the potential loss of nitrate from discharging groundwater (table 7; eq. 1).

The part of the watershed covered by each land-use group was delineated based on the National Land Cover (NLCD) 2011 dataset (Homer and others, 2015). Concentrations of nitrate discharging from agricultural areas were estimated based on the range of concentrations measured for this study in the instream piezometers $(15-17 \mathrm{mg} / \mathrm{L}$ as $\mathrm{N})$. A constant concentration of $0.4 \mathrm{mg} / \mathrm{L}$ as N was applied to the forested/ wetland area based on previous research in natural parts of the local area (Hamilton and others, 1993). A constant concentration of $2.7 \mathrm{~m} / \mathrm{L}$ as $\mathrm{N}$ was applied to the residential area, based on results of recent sampling in a residential area of Sussex County, Delaware (Kasper, 2014). Nitrate concentrations for each group were multiplied by the proportion of each land use and added together to estimate the 


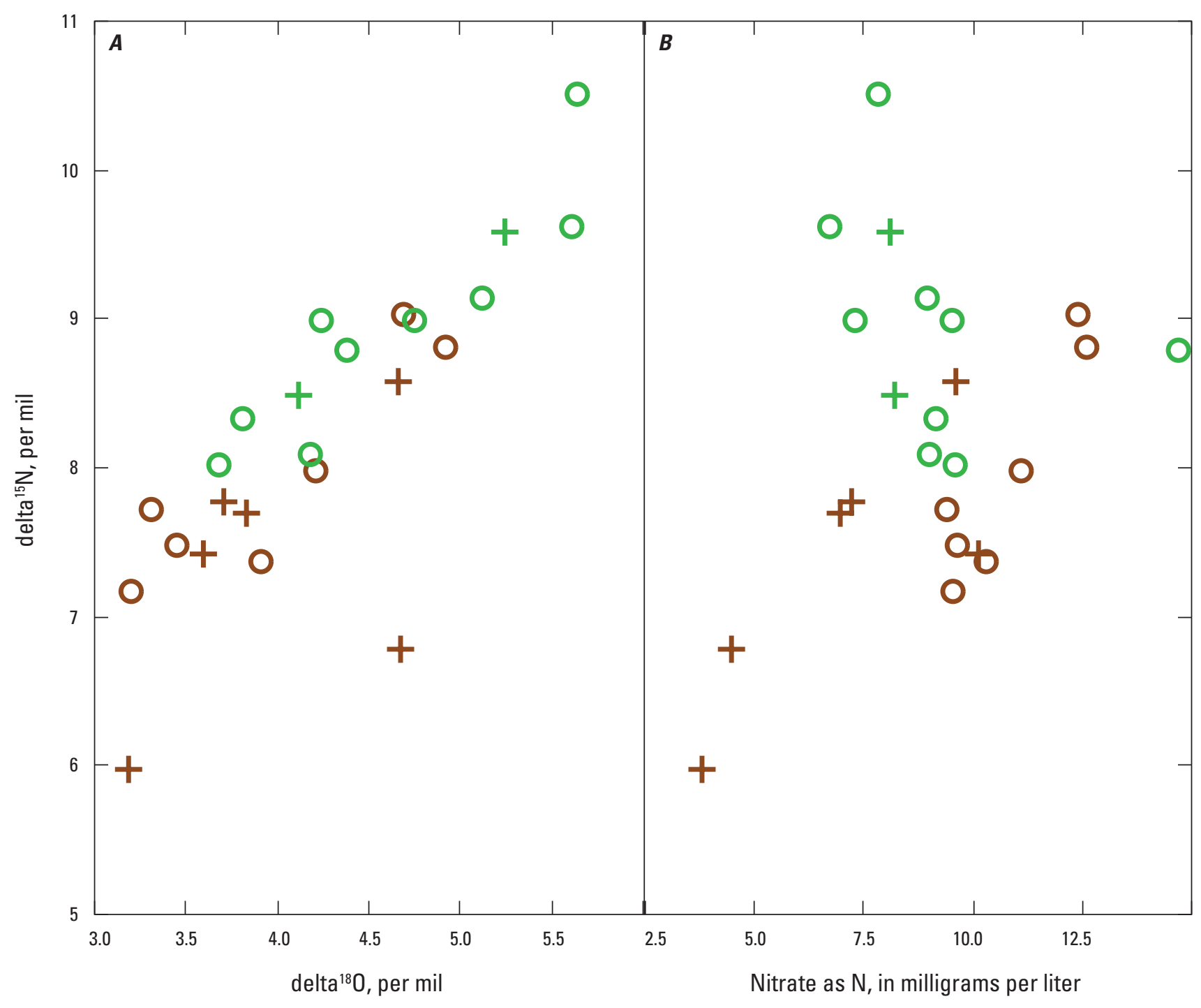

EXPLANATION

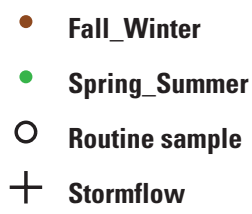

Figure 21. Trends in $A$, the ratio of the nitrogen (delta ${ }^{15} \mathrm{~N}$ ) and oxygen (delta ${ }^{18} \mathrm{O}$ ) isotopes of nitrate, and $B$, delta ${ }^{15} \mathrm{~N}$ and nitrate in water by season and flow conditions, site SW2, Bucks Branch study site, Sussex County, Delaware. 
Table 7. Mixing model input data and model output used for estimating the loss of nitrate from groundwater discharging to surface water at site SW2, Bucks Branch, Sussex County Delaware.

[\%, percent; $\mathrm{mg} / \mathrm{L}$ as $\mathrm{N}$; milligrams per liter as nitrogen]

Model input data:

\begin{tabular}{l|ccccc}
\hline \multicolumn{1}{c|}{ Land-use class } & Units & C1, Wetland + Forest & C2, Agricultural & C3, Residential & C4, Surface water \\
\hline Area & square miles & 0.935 & 2.178 & 0.161 & 3.273 \\
Land-Use Proportion & & 0.290 & 0.660 & 0.050 & 1 \\
Land-Use Percent of Area & $\%$ & 28.566 & 66.527 & 4.907 & \\
Nitrate Minimum & $\mathrm{mg} / \mathrm{L}$ as N & & 15 & 2.7 \\
Nitrate Median & $\mathrm{mg} / \mathrm{L}$ as N & 0.4 & 16 & 17 & \\
Nitrate Maximum & $\mathrm{mg} / \mathrm{L}$ as N & & & 9 \\
Nitrate Median Measured & $\mathrm{mg} / \mathrm{L}$ as N & & & \\
\hline
\end{tabular}

Model output:

\begin{tabular}{l|cccc}
\hline & Units & Minimum & Median & Maximum \\
\hline totalN: Groundwater nitrate input & $\mathrm{mg} / \mathrm{L}$ as N & 10.2 & 10.9 & 11.6 \\
Nloss: Loss of nitrate from groundwater & $\mathrm{mg} / \mathrm{L}$ as N & 1.2 & 1.9 & 2.6 \\
Percent loss of nitrate & $\%$ & 12 & 17 & 22 \\
\hline
\end{tabular}

potential total nitrate concentration in inflowing groundwater throughout the watershed prior to the potential loss in nearstream anoxic discharge areas (eq. 1). The modeled total estimated concentrations of nitrate in discharging groundwater ranged from 10.2 to $11.6 \mathrm{mg} / \mathrm{L}$ as $\mathrm{N}$ (table 7). The percent loss of nitrate was estimated by subtracting the median stream nitrate concentration of $9 \mathrm{mg} / \mathrm{L}$ as $\mathrm{N}$ from the total estimated nitrate concentrations from the three models with differences in agricultural nitrate inputs in discharging groundwater (eq. 1). The percent difference between the loss of nitrate and total estimated nitrate concentrations in discharging groundwater was then calculated (eq. 2; table 7).

Nloss $=\left\{\left[\left(C 1 *\right.\right.\right.$ median $\mathrm{NO}_{3}-\mathrm{N}$ of $\left.\mathrm{Cl}\right)+$

$\left(\mathrm{C} 2 *\right.$ median, maximum, or minimum $\mathrm{NO}_{3}-\mathrm{N}$ of $\left.\mathrm{C} 2\right)+$

$\left(\mathrm{C} 3 *\right.$ median $\mathrm{NO}_{3}-\mathrm{N}$ of $\left.\left.\left.\mathrm{C} 3\right)\right]-\mathrm{C} 4\right\}$

Percent loss of nitrate $=($ Nloss $/$ totalN $) * 100$

where
Nloss
is the estimated loss of nitrate $\left(\mathrm{NO}_{3}-\mathrm{N}\right)$ in groundwater discharging to surface water;
totalN is modeled $\mathrm{NO}_{3}-\mathrm{N}$ input from groundwater to surface water;
C1 is percent of wetland and forest land;
$C 2$ is the percent of agricultural land;
$C 3$ is the percent of residential land; and
$\mathrm{C} 4$ is the $\mathrm{NO}_{3}-\mathrm{N}$ measured in surface water.

The estimated total loss of nitrate ranged between 12 and 22 percent of potential groundwater inputs (table 7).
This loss probably occurred primarily in shallow parts of the aquifer near the stream, and affects younger water flowing along shallow flowpaths, although some loss could occur in deeper parts of the flow system where denitrification also has been observed (figs. 4 and 13). When the water table is low and wetland sediments are dry, more water that has not been affected by loss through denitrification in shallow near-stream sediments can potentially flow into the stream, as indicated by the higher nitrate concentrations during lower base flows shown in figure 19.

\section{Comparison of the Intensive Surface-Water Site to Watershedwide Surface-Water Quality in Bucks Branch}

Ten sites were sampled synoptically three times during high base flow in the spring to examine the distribution of nitrate in surface water around the Bucks Branch watershed (fig. 1). The watershed has two main branches that provide over two-thirds of the flow to the most downstream site at SW1: Bucks Branch at SW2, which was measured intensively for this study, and Freidel Prong (site SW3) (fig. 22). Most of the other sites sampled around the watershed are upstream of sites SW2 or SW3, with the exception of SW10, Gilbert Trivitts Ditch in the eastern part of the watershed (fig. 1). Flow at SW3 is much less than at SW2 in the main stem of the watershed, but concentrations of nitrate were higher, probably because this tributary has less riparian buffer than SW2 (fig. 22). The tributary at SW10 is a relatively shallow ditch with low flow and has little influence on stream quality. 


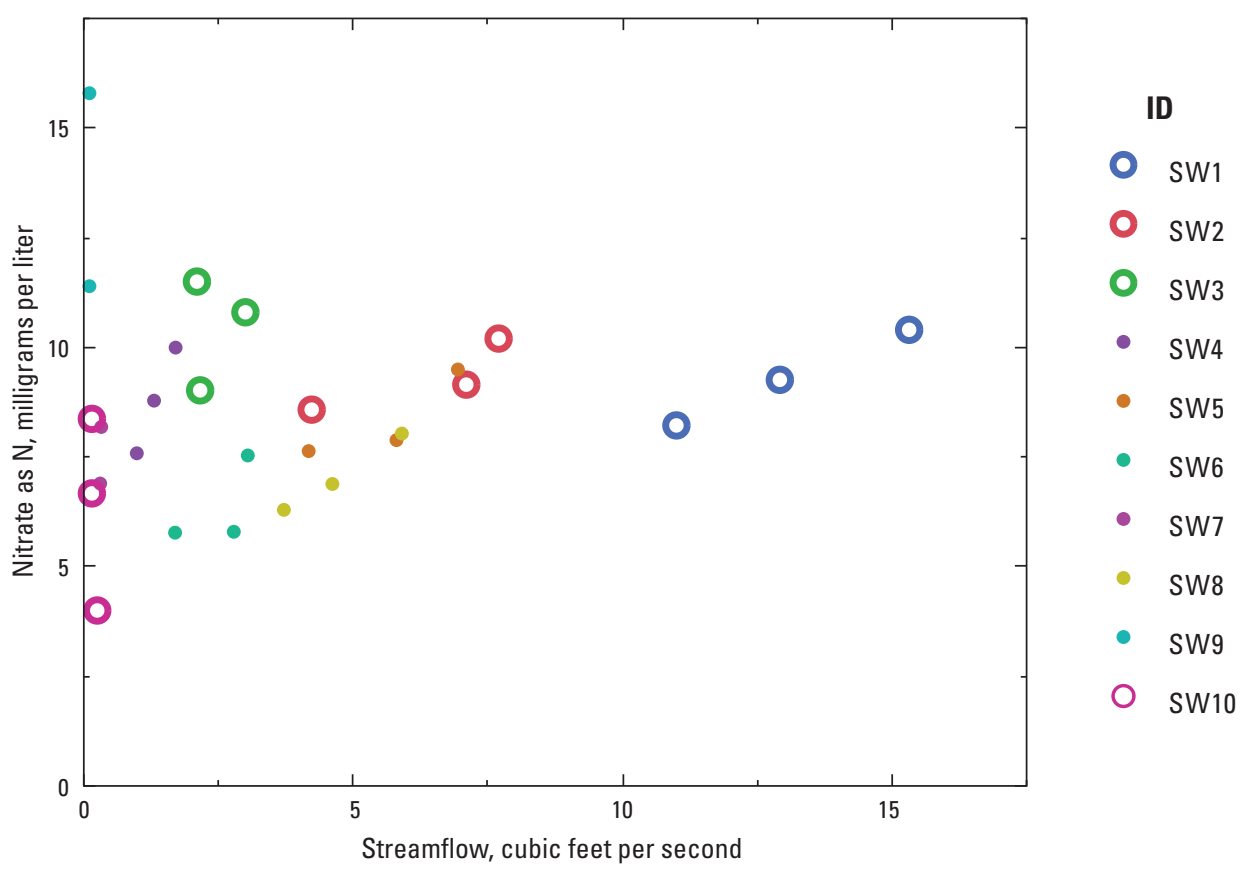

Figure 22. Spring base-flow synoptic sampling showing relation of streamflow to nitrate concentrations in surface water collected around the Bucks Branch watershed, Sussex County, Delaware, 2014-16. [Synoptic sampling sites shown on figure 1.]
DNREC has collected data samples from the outlet of Bucks Branch at site SW1 since 2003 (fig. 1; Delaware Water Quality Portal, [2017]). The median concentration of nitrate for multiple samples from SW1 plotted by month is very close to $9 \mathrm{mg} / \mathrm{L}$ as $\mathrm{N}$, which is the median measured for this study at SW2 (fig. 23). Changes in water quality during flow and season at SW2 are probably representative of processes throughout the Bucks Branch watershed. Concentrations of dissolved phosphorus and nitrate follow similar trends as shown in figure 19 at SW2. The downward trend in nitrate and upward trend in phosphorus in the summer months is consistent with the likelihood of nutrient processing in the stream during that time (fig. 23). The application of manure and ammoniumbased fertilizers is the likely cause of the earlier increased ammonia concentrations in the spring.

\section{Effects of Cover Crops on Soil and Water}

The effects of cover crops on soil and water quality were studied following the 2015 growing season. Cover crops are utilized by the Bucks Branch farmer to raise soil fertility and decrease soil compaction. In 2015, the producer was enrolled in a pilot air-seeding program with the Sussex Conservation District, which helps the farmer plant cover crops. The airseeding program utilizes specialized equipment, owned by the conservation district, and allows for planting cover crops into standing corn in late summer. Cover crops planted in late summer instead of fall have more time to grow and develop root systems and utilize soil nutrients. In 2015 at the Bucks Branch study site, radishes and rye grass were planted on the irrigated field whereas only rye was planted on the dryland field. Radishes were air-seeded on the irrigated field in mid-August prior to crop removal. A clogged planting nozzle led to only strips of radish plants on the field. After crop removal on both fields, the producer planted rye over the entire area of the fields, including the parts of the irrigated field with radish plants. As a result, the irrigated field had strips of radish and rye plants, and strips with only rye (fig. 24).

Overall plant production can be compared by the amount of plant tissue, or biomass, produced. When dried for chemical analysis, biomass is known as dry matter (DM) and is directly related to overall plant productivity from rye and radish plants. The difference between living tissue and DM is the weight of water held within plant vascular systems. Nutrient balances of fields are attained by multiplying DM by nutrient concentration. At the December sampling time, radish above and below ground DM was estimated at 1,600 pounds per acre (lb/acre) whereas rows only covered with rye produced $660 \mathrm{lb} /$ acre DM. The mass of radish tubers produced more DM (1,000 lb/acre) than radish shoots (leaves) (600 lb/acre). Radish shoots, however, had a higher nutrient uptake due to greater nutrient concentrations per pound of DM (table 8).

Samples of plant tissue were collected, weighed, and processed for analysis of nutrients and ions important to plant growth on December, 17, 2015 (table 8). Nutrient uptake by radishes was typically higher than uptake by rye or other green material inter-seeded with radishes on the irrigated field. Radish growth was intensive and produced large tubers with several in excess of $5 \mathrm{lbs}$ (fig. 24). Nitrogen concentrations in the radish tubers and shoots of radish were within, but lower than, nitrogen content ranges reported by other researchers (Dean and Weil, 2009; Lainé and others, 1993). Samples of biomass in the radish crop contained less nitrogen compared to other studies on radishes planted earlier in the Mid-Atlantic Coastal Plain (Ray Weil, University of Maryland, written commun., 2017). Despite their large size, lower nitrogen yields 


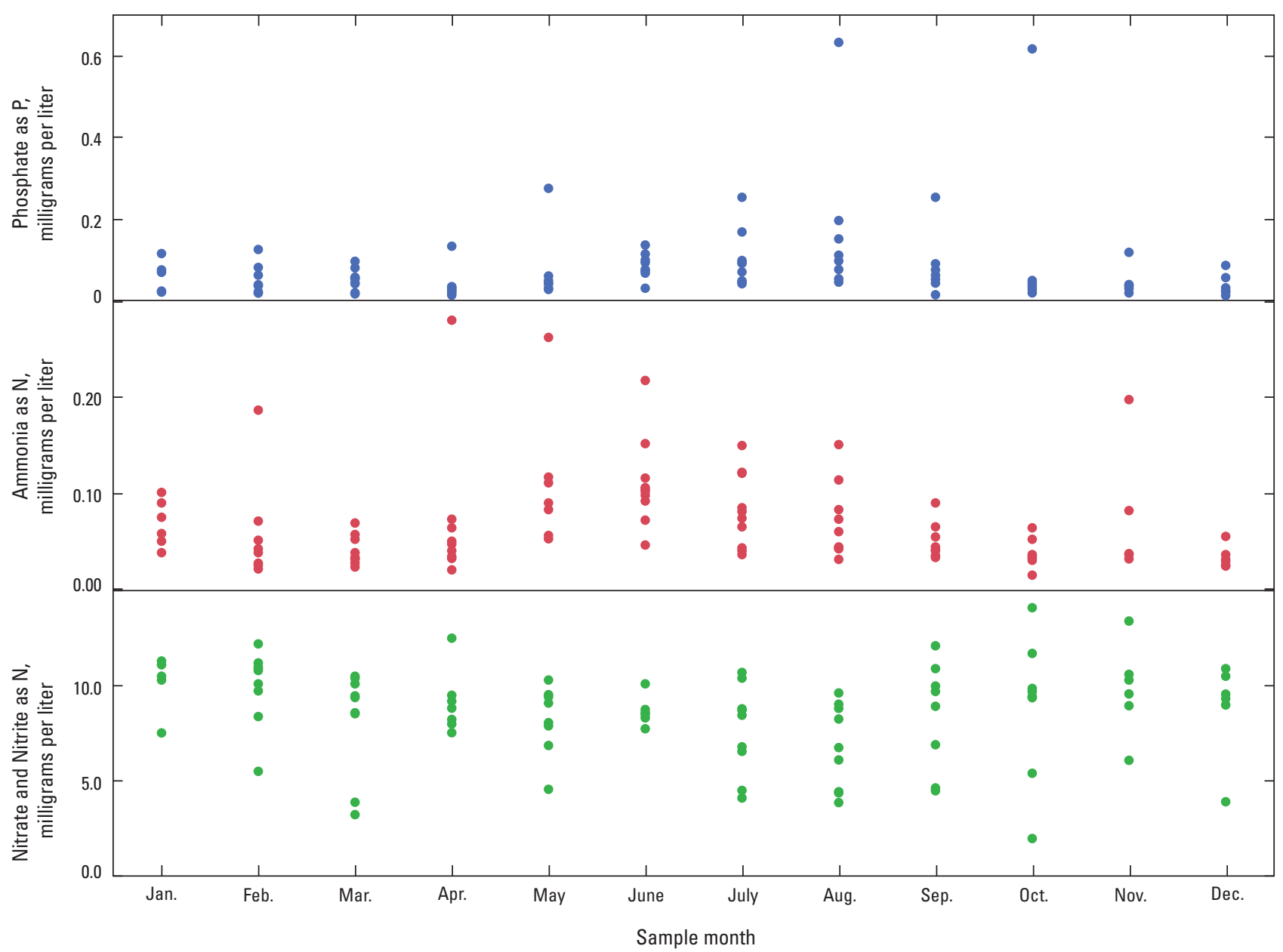

Figure 23. Nutrient data by month for the watershed outlet at SW1, Bucks Branch, Sussex County, Delaware, 2003-12. [Location of site SW1 shown on figure 1.]

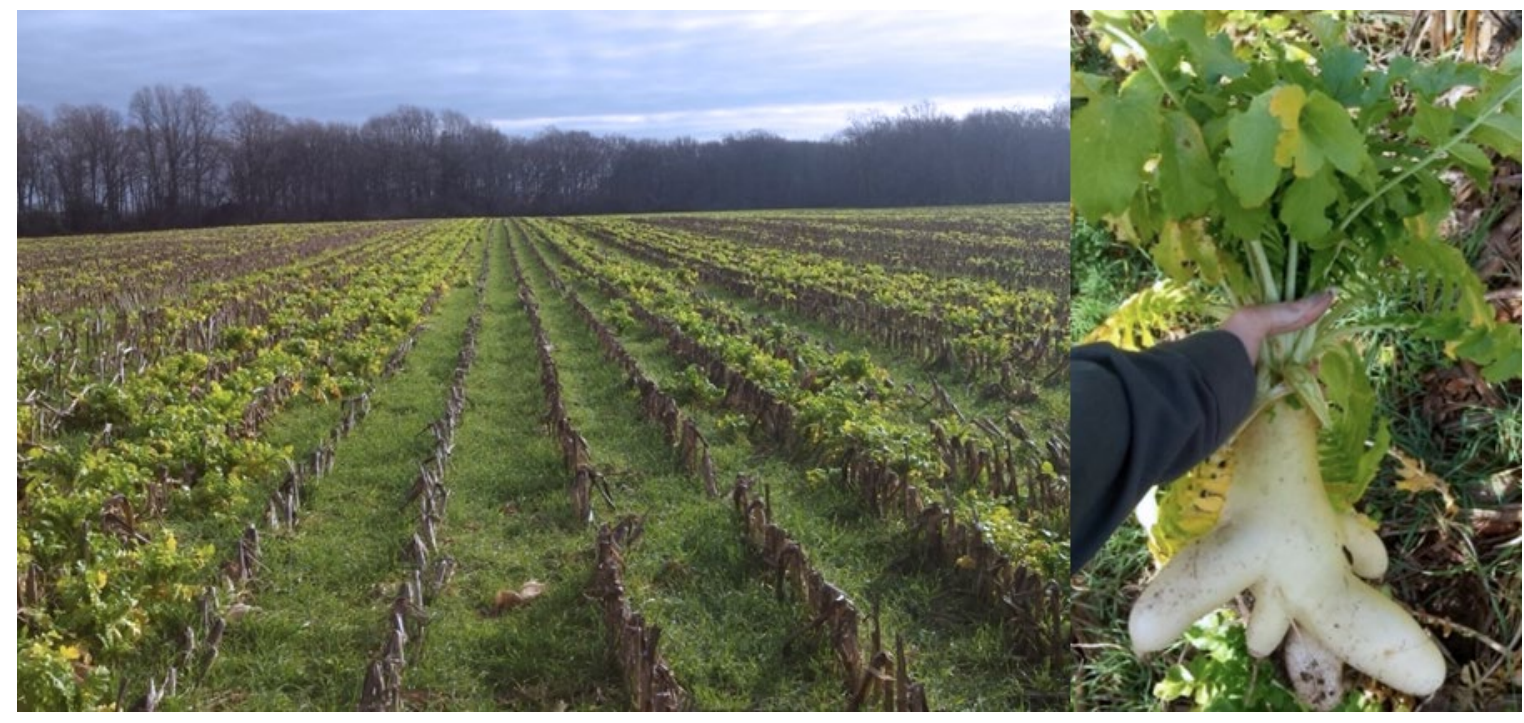

Figure 24. Alternating rows of rye and radish at the study site with a radish shown on the right to demonstrate the possible size of a radish tuber in the irrigated field, Bucks Branch study site, Sussex County, Delaware. Photographs by Alexander Soroka, U.S. Geological Survey 
Table 8. Cover crop biomass nutrient content prior to radish die-off from freezing (pre-kill; December 17, 2015) and following radish die-off (post-kill; April 11, 2016) in the irrigated field at the Bucks Branch study site, Sussex County, Delaware.

[Total N, total amount of nitrogen; Total C, total amount of carbon; P, phosphorus; K, potassium; Ca, calcium; Mg, magnesium; S, sulfur; Zn, zinc; Fe, iron; $\mathrm{B}$, boron; lb/acre, pounds of nutrient estimated in plant biomass per acre of plant]

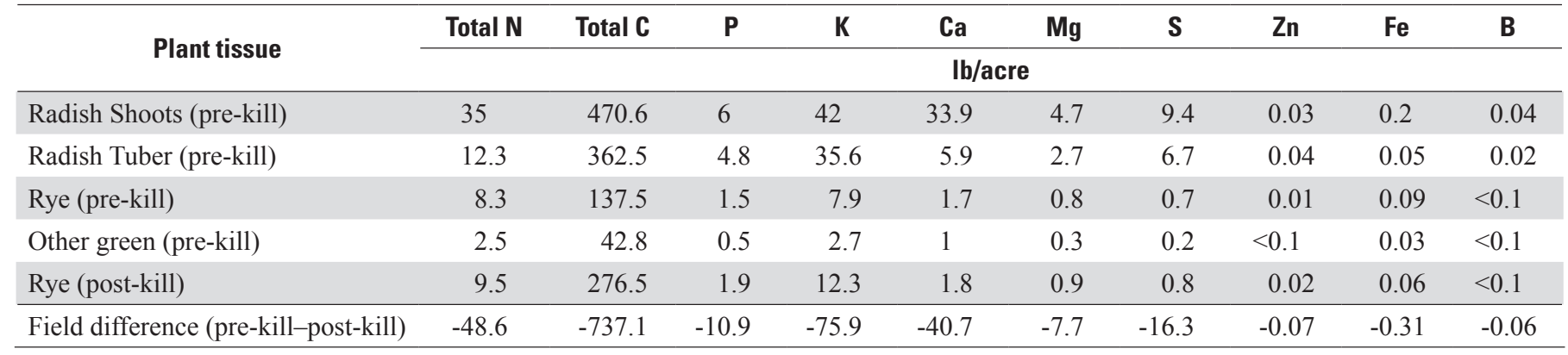

could be due to sub-optimal nitrogen levels for plant growth in the soil. Evidence of low soil nitrogen fertility was provided by discoloration of some radish leaves, known as chlorosis, which is indicated by an overall pale yellowish-green color with yellowing near the plant veins (Brady and Weil, 2008).

Radishes perished following several consecutive days of freezing weather in mid-January 2016. When the second biomass sampling occurred on April 11, 2016, the entire field was covered with rye grass and radish plots were undiscernible. Post-kill values shown in table 8 were considered to be an average of the two (as sampling rate of radish or rye prior to winter kill was nearly a $1: 1$ ratio). These data indicate that a loss of $48.6 \mathrm{lb} /$ acre of nitrogen in biomass of the radishes was not absorbed by the rye crop (table 8).

Nutrient uptake by rye plants on the dryland field continued through winter to the time of sampling, which generally resulted in higher nitrogen held in biomass after the second sampling date than after the first (table 9). Biomass increased by more than 300 percent from $460 \mathrm{lb} /$ acre DM in the first sample (December 17, 2015) to $1,700 \mathrm{lb} /$ acre DM in the second sample (April 11, 2016). Over the course of the winter, the dryland field rye crop held a total of $28.4 \mathrm{lb}$ /acre of nitrogen within its biomass.

No significant difference was observed in soil chemistry between areas dominated by radish or rye on the irrigated field prior to radish die-off (all t-test parameters had $p>0.31$; $p<0.05$ is significant). Significant differences in soil chemistry were apparent between the December and April sampling dates on both fields (table 10). The differences in soil chemistry were observed following radish die-off (on the irrigated field), increasing average temperatures associated with spring, and the subsequent soil thaw. Changes in soil chemistry could be due to soil microbial metabolism, which released nutrients stored as organic matter $(\mathrm{OM})$. The release of nutrients from OM by microbes in warming periods of spring is well documented (Brady and Weil, 2008). As this study did not sample fields devoid of cover crops, it is uncertain if cover crops aided in raising soil fertility.

Samples of soil water collected during the cover crop experiment generally had lower concentrations of nitrate compared to shallow groundwater samples collected during the main growing season (figs. 10 and 25). Differences between rye- and radish-dominated parts of the field were not apparent in soil water (fig. 25). Chemical constituents of soil water under the dryland field were poorly characterized due to only two samples being obtained (fig. 26). An increase in soil dissolved organic nitrogen (DON) was apparent during soilwater sampling of the irrigated field from the initial samples collected in February and early April (fig. 26B). Higher $\mathrm{DON}$ is associated with a release of nitrogen from microbial

Table 9. Cover crop biomass nutrient content prior to radish die-off from freezing (pre-kill, December 17, 2015) and following radish die-off (post-kill, April 11, 2016) in the dryland field at the Bucks Branch study site, Sussex County, Delaware.

[lb/acre, pounds of nutrient estimated in plant biomass per acre of plant; Total N, total amount of nitrogen; Total C, total amount of carbon; P, phosphorus; $\mathrm{K}$, potassium; Ca, calcium; Mg, magnesium; S, sulfur; Zn, zinc; Fe, iron; $\mathrm{B}$, boron]

\begin{tabular}{lllllllllll}
\hline \multicolumn{1}{c}{ Plant tissue } & Total N & Total C & P & K & Ca & Mg & S & Zn & Fe & B \\
\hline & & \multicolumn{7}{c}{ lb/acre } \\
\hline Rye (pre-kill) & 16.6 & 191 & 2.6 & 13.7 & 1.6 & 1 & 1 & 0.02 & 0.17 & 0 \\
Rye (post-kill) & 28.4 & 741.3 & 6 & 41.2 & 3.9 & 2.2 & 2.3 & 0.04 & 0.08 & 0.01 \\
\hline Field difference & 11.8 & 550.3 & 3.5 & 27.5 & 2.3 & 1.2 & 1.2 & 0.02 & -0.09 & 0.01 \\
\hline
\end{tabular}


Table 10. Soil fertility results for the top foot of soil from the dryland and irrigated fields associated with the Bucks Branch study site, Sussex County, Delaware.

[One-way analysis of variance tested the difference between December and April soil fertility; light shading corresponds to significance at $p \leq 0.05$; darker shading refers to significance at $p \leq 0.001 ; \mathrm{n}$, number of samples; $\mathrm{mg} / \mathrm{kg}$, milligrams per kilogram of soil; bold, mean; min, minimum; max, maximum]

\begin{tabular}{|c|c|c|c|c|}
\hline \multirow{2}{*}{ Parameter } & \multicolumn{2}{|c|}{ Dryland field } & \multicolumn{2}{|c|}{ Irrigated field } \\
\hline & 12/7/2015; n=4 & 4/22/2016; n=8 & 12/7/2015; n=16 & 4/22/2016; n=15 \\
\hline \multicolumn{5}{|c|}{ Percent: Mean (min-max) } \\
\hline Total nitrogen & $\mathbf{0 . 0 8}(0.07-0.1)$ & $\mathbf{0 . 0 9}(0.07-0.11)$ & $\mathbf{0 . 0 7}(0.06-0.1)$ & $\mathbf{0 . 0 8}(0.07-0.11)$ \\
\hline Total carbon & $\mathbf{0 . 8 6}(0.67-1.1)$ & $\mathbf{0 . 9 1}(0.66-1.1)$ & $\mathbf{0 . 7 7}(0.63-1.1)$ & $\mathbf{0 . 8 6}(0.67-1.2)$ \\
\hline \multicolumn{5}{|c|}{$\mathrm{mg} / \mathrm{kg}$ : Mean (min-max) } \\
\hline Ammonium as nitrogen & $2.2(2.1-2.4)$ & $4.6(3.7-5.6)$ & $1.7(1.4-2.2)$ & $4.5(3.1-7.6)$ \\
\hline Nitrate as nitrogen & $1.8(1.7-2.1)$ & $2.4(1.8-2.9)$ & $1.2(0.2-2.6)$ & $2.9(1.8-4.5)$ \\
\hline Phosphorus & $422(269-558)$ & $\mathbf{5 0 8}(340-692)$ & $153(60.3-228)$ & $162(75.7-236)$ \\
\hline Potassium & $\mathbf{1 2 9}(101-153)$ & $161(127-230)$ & $70.2(52.1-112)$ & $87.2(48.6-155)$ \\
\hline Calcium & $\mathbf{6 3 0}(485-742)$ & $695(552-1,131)$ & $334(206-457)$ & $392(248-501)$ \\
\hline Magnesium & $128(98.1-146)$ & $\mathbf{1 2 5}(96.9-150)$ & $75.2(49.3-91.5)$ & $85(54-122)$ \\
\hline Manganese & $\mathbf{1 7 . 8}(13.5-20.5)$ & $23.9(20.6-28.8)$ & $11(5.7-18.2)$ & $13.7(8.5-22.2)$ \\
\hline Zinc & $11.4(8.5-14.2)$ & $11.7(10.1-17)$ & $4.8(3-6.7)$ & $5.8(3.5-7.1)$ \\
\hline Copper & $7.8(7-8.5)$ & $8.5(7.7-10)$ & $3.7(2.4-5.3)$ & $4.3(3-5.6)$ \\
\hline Iron & $126(91.2-155)$ & $162(127-194)$ & $101(72.8-142)$ & $117(91.3-163)$ \\
\hline Boron & $\mathbf{0 . 8 6}(0.65-1)$ & $\mathbf{1 . 1}(0.93-1.6)$ & $\mathbf{0 . 5 9}(0.43-0.79)$ & $\mathbf{0 . 7 3}(0.61-0.98)$ \\
\hline Sulfur & $8.6(6.9-10.5)$ & $\mathbf{1 0 . 2}(8.9-11.8)$ & $8.2(6.2-10.2)$ & $10.2(7.3-13.4)$ \\
\hline Aluminum & $\mathbf{6 8 8}(541-817)$ & $936(760-1,155)$ & $572(446-753)$ & $674(580-854)$ \\
\hline
\end{tabular}

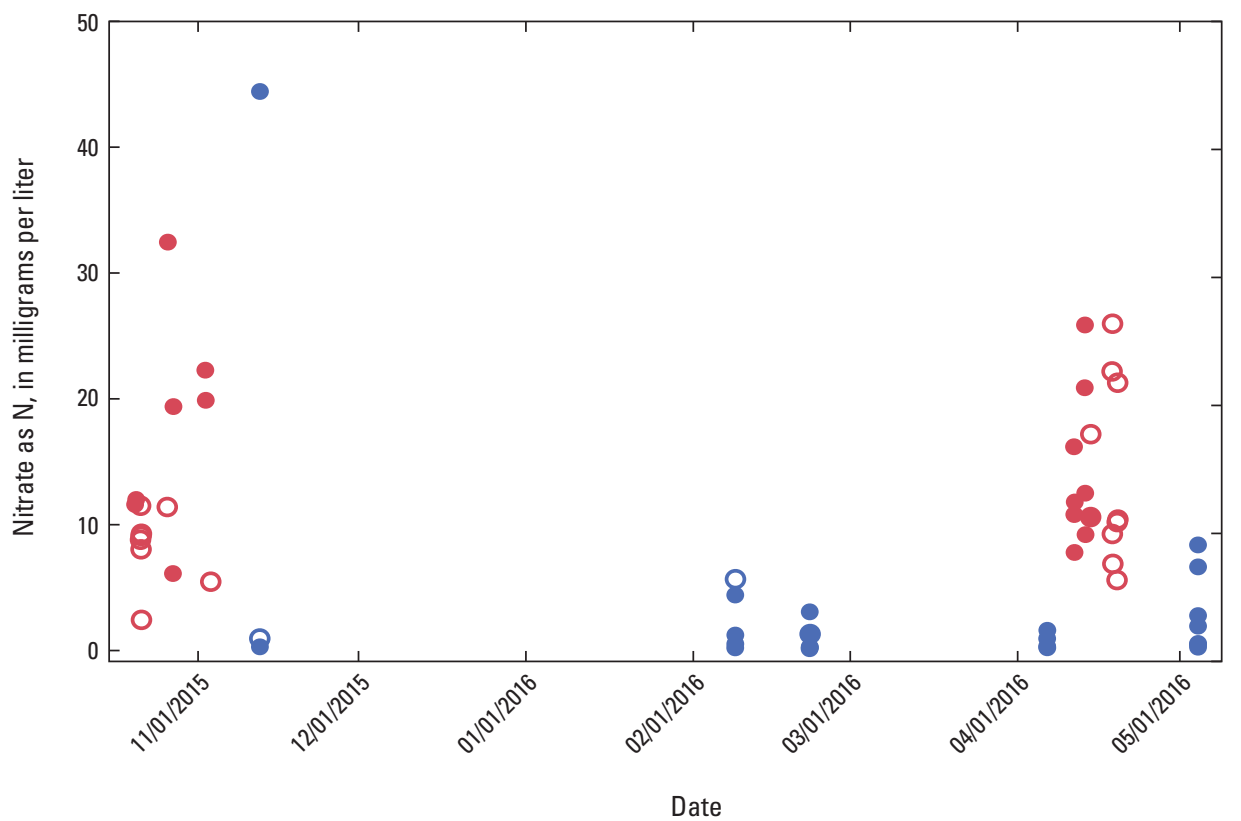

Figure 25. Nitrate as nitrogen concentrations for shallow and medium depth wells (red) and soilwater lysimeters (blue) over time from irrigated (closed circle) and dryland (open circle) fields at the Bucks Branch study site, Sussex County, Delaware. 


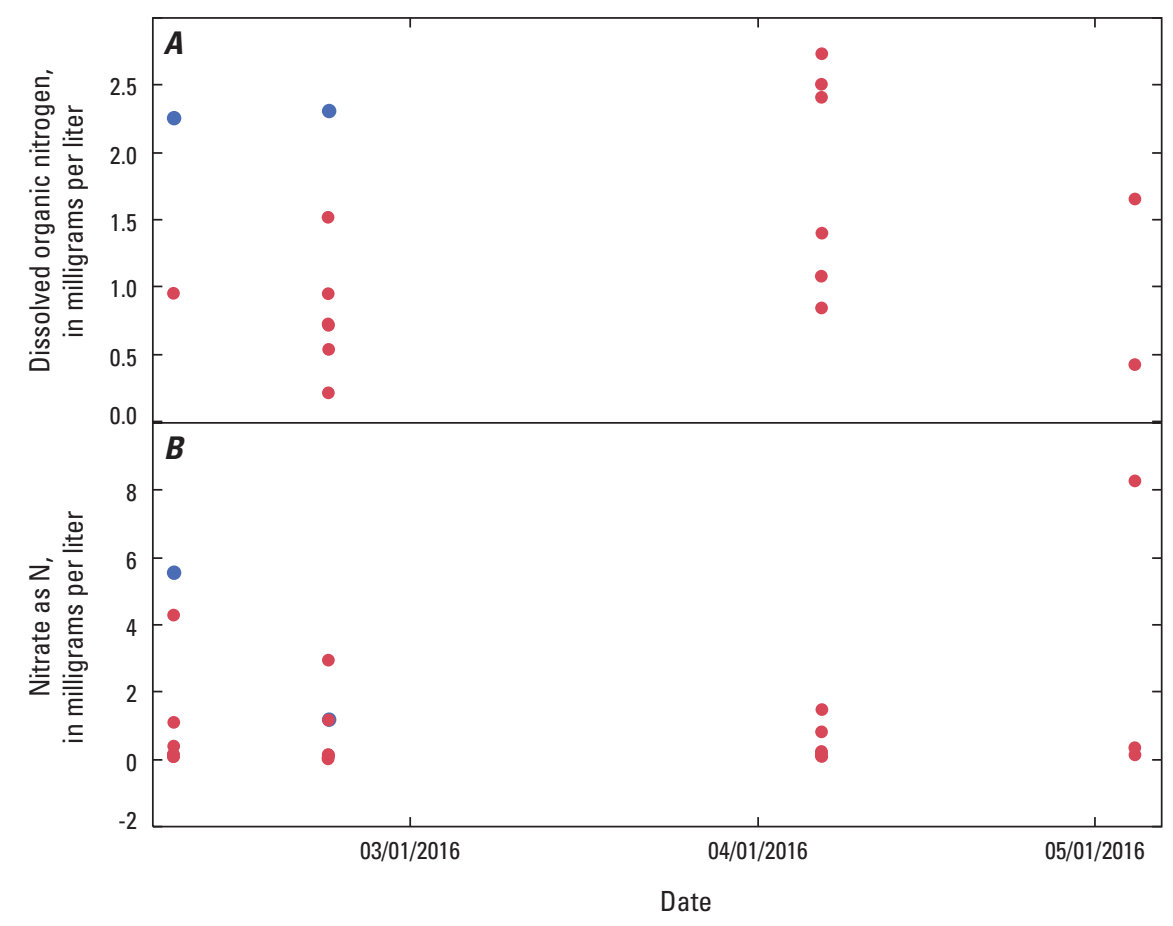

Figure 26. Soil-water samples of $A$, nitrate as nitrogen and $B$, dissolved organic nitrogen from irrigated (red) and dryland (blue) fields at the Bucks Branch study site, Sussex County, Delaware. breakdown of OM, but could also come from previous poultry manure applications (Singh and others, 2013). DON concentrations were similar to nitrate concentrations in soil water during the cover crop season (fig. 26).

Evidence indicates that the radish crop effectively scavenged available $\mathrm{N}$ from the soil and that leaching of inorganic nitrate during this time was minimal. An increase in soil fertility and dissolved organic nitrate in springtime was likely related to soil microbial metabolism. Soil-water nitrate concentrations during the cover-crop growing period were lower than those during the corn growing season, as shown in figure 10. Results indicate that cover crops had a positive impact in storing plant nutrients over the winter, and did not increase shallow groundwater concentrations of nitrate.

\section{Summary and Conclusions}

Bucks Branch in the Nanticoke River watershed in southwestern Delaware was identified as having one of the highest concentrations of nitrate in surface water of all stream sites sampled by the Delaware Department of Natural Resources and Environmental Control. The purpose of this study was to evaluate the effects of current conservation practices on water quality in the Bucks Branch watershed in Sussex County, Delaware. Conservation practices during the study included the analyzing the effects of irrigation on nutrient transport to groundwater compared to nutrient transport under dryland farming, and the effect of cover crops on nutrient transport.
Surface-water quality and the transport of nutrients to surface water also were studied as part of this project.

The study site was located on two adjacent fields, one that has been irrigated since 2000, and one with dryland farming. Both were under conservation tillage and long-term rotation of corn, soybean, and small grain crops. Corn was grown on both fields during the two growing seasons of the study period, and cover crops were planted before or closely after harvest on both fields. The effects of cover crops on nutrient transport were studied in 2015 after the growing season. The study area represents farming and environmental conditions throughout intensively farmed agricultural land in the Coastal Plain of Delaware and the surrounding part of Maryland on the Delmarva Peninsula. The fields on the farm in the study area have a nutrient management plan developed by the Sussex Conservation District, which was based on nutrient management recommendations from the University of Delaware Cooperative Extension. Staff from the Cooperative Extension worked with the U.S. Geological Survey on this project to better understand nutrient uptake by crops to determine nutrient use efficiencies under irrigated and dryland crop production.

The Bucks Branch watershed overlies a thick surficial aquifer with a shallow water table overlain by predominantly well-drained sandy soils. Rainfall frequency and intensity over the study period was average, with no major storm events. Most recharge to the water table occurred during the colder months when evapotranspiration is low, but groundwater recharge also occurred after significant rainfall during the growing season. Water levels indicated that recharge to the groundwater system was more likely during the growing season under the irrigated field than under the dryland field. 
When rainfall occurred during the growing season, samples of soil water showed that water and chemicals were transported below the root zone (about 3 feet [ft] below land surface) towards the groundwater system under both fields. Movement of water and nitrate to groundwater was enhanced by greater soil moisture conditions beneath the irrigated field. Soil-water concentrations of nitrate were highest beneath both fields during the growing season, and were approximately 125 milligrams per liter as nitrogen $(\mathrm{mg} / \mathrm{L}$ as N) and about $240 \mathrm{mg} / \mathrm{L}$ as $\mathrm{N}$ at the $1-\mathrm{ft} \mathrm{depth}$, and about $20 \mathrm{mg} / \mathrm{L}$ as $\mathrm{N}$ and over $100 \mathrm{mg} / \mathrm{L}$ as $\mathrm{N}$ at the $3-\mathrm{ft}$ depth under the dryland and irrigated fields, respectively. Concentrations of nitrate in wells screened near the water table were similar to the median of those in samples from the 3 - $\mathrm{ft}$ lysimeters. Although orthophosphate was measured in some soil-water samples, the median concentration was less than $0.01 \mathrm{mg} / \mathrm{L}$ in groundwater samples.

Groundwater beneath both fields is dominated by agricultural chemicals used for the production of corn, soybeans, and small grains, including manure, inorganic nitrogen fertilizer, lime, and potassium chloride. Overall, the irrigated site had higher median specific conductance and concentrations of major ions including nitrate, calcium, magnesium, and chloride. Nitrate was present in all groundwater samples, ranging from 1 to $46 \mathrm{mg} / \mathrm{L}$ as $\mathrm{N}$, with a median of about $9 \mathrm{mg} / \mathrm{L}$ as $\mathrm{N}$ beneath the dryland field, and $14 \mathrm{mg} / \mathrm{L}$ as $\mathrm{N}$ beneath the irrigated field.

The measured apparent age of groundwater ranged from less than 10 to about 37 years. Groundwater estimated to have recharged within 10 years or less had higher median concentrations of nitrate beneath both fields, but the median concentration was highest in young water beneath the irrigated field — about $18 \mathrm{mg} / \mathrm{L}$ as N compared to about $10 \mathrm{mg} / \mathrm{L}$ beneath the dryland field. Water beneath the irrigated field that recharged the aquifer prior to irrigation (less than 15 years) had lower concentrations of nitrate than younger water. Beneath the dryland field, the water quality in deeper parts of the aquifer was likely affected by recharge from an upgradient field that was not typically used for corn and soybean production. The longest flowpaths to reach the stream are under the uplands of the fields, where water will travel for several decades along deep flowpaths to the stream.

Over 90 percent of flow in Bucks Branch is from groundwater and the chemistry of surface water resembles that of groundwater affected by agricultural land use. The median nitrate concentration in Bucks Branch at streamgage site SW2 was $9 \mathrm{mg} / \mathrm{L}$. Trends related to flow and season in water quality were seen in both discrete and continuous samples at SW2. Concentrations of dissolved nitrogen species that are contributed from groundwater generally decrease with increasing flow during storms, as do other dissolved constituents such as silica, especially during the colder months. Total phosphorus, ammonia, and potassium concentrations are higher during storms than during base flow, although concentrations of dissolved phosphorus are similarly low during base flow and stormflow. Concentrations of nitrate during base flow are higher in stream water during the colder months than during the warmer months with the same flow rate, likely because of decreases in nitrate caused by instream biological processing during the warmer months.

Continuous specific conductance, dissolved oxygen, $\mathrm{pH}$, and temperature data also showed trends. Specific conductance generally decreased with increasing flow, with the exception of some storms that occurred during the beginning of the growing season when fields were being worked and the greater potential for sediment transport also affected specific conductance. Dissolved oxygen has daily diurnal variation throughout the year related to community respiration, with a maximum daily variation exceeding $8 \mathrm{mg} / \mathrm{L}$ as temperature and light increases in the spring and the stream is filled with extensive blooms of floating aquatic plants. Nitrate fluctuated about $1 \mathrm{mg} / \mathrm{L}$ as $\mathrm{N}$ daily during the spring period of high community respiration. Rooted vegetation dominates instream plants over the remainder of the year, and the diurnal fluctuation is usually between 2 to $4 \mathrm{mg} / \mathrm{L}$. Although water temperature is closely related to air temperature, because of continuous groundwater discharge with a mean temperature of about 15 degrees Celsius, the stream water rarely freezes. The $\mathrm{pH}$ of water ranged between 6 and 7 and also fluctuated daily.

Although nitrate is relatively high in stream water, an increasing trend in the ratio of nitrogen and oxygen isotopes of nitrate in surface water and in some near-stream groundwater samples indicated that loss of nitrate through denitrification has affected the chemistry of stream water. Continuous data collected at this site and evidence of denitrification in the surface-water samples showed a greater potential for loss of nitrate through uptake by aquatic plants and denitrification during the warmer months than during the colder months. This pattern was similar to that seen at site SW1, the most downstream site in the watershed. Between 12 to 22 percent of nitrate in groundwater was estimated to be lost through denitrification prior to discharge into Bucks Branch using a mixing model. Most of the loss probably occurred where groundwater with nitrate came into contact with anoxic riparian wetland sediments, although some loss also occurred in deeper groundwater samples prior to stream discharge.

Cover-crop biomass samples of radishes and rye grass collected before and after winter die-off of radishes indicates that the early planted radish crop effectively scavenged available nitrogen from the soil. Whereas radishes initially held more nitrogen than rye, at 55 to 8 pounds per acre, respectively, leaching of inorganic nitrate during this time was minimal. Soil-water nitrate concentrations during the covercrop growing period were lower than those during the growing season. An increase in soil fertility and dissolved organic nitrate observed in the springtime was likely related to soil microbial metabolism. Results indicate that cover crops had a positive impact in storing plant nutrients over winter and did not increase shallow groundwater concentrations of nitrate.

The combined results from data collected for this study showed that water and nutrients are carried below the root zone and through the soil zone in infiltrating water year round 
when soil moisture is high after significant rainfall and after irrigation. Water infiltrating below the soil zone shortly after nutrients were applied had the highest nitrate concentrations, often greater than $50 \mathrm{mg} / \mathrm{L}$, and may be a significant source of nitrate to groundwater. Once nitrate enters the groundwater system beneath these fields, there is a high likelihood of it reaching the stream.

Although conservation practices have been applied to the fields, there is still significant leaching of nitrate to groundwater. This is especially true under the irrigated field, where nitrate concentrations are higher in younger water recharged since irrigation began on this field. Continued research on irrigation and nutrient management practices that reduce leaching, especially in well-drained upland areas, will be necessary to improve the precision and nutrient uptake efficiency of these practices in the future. Cover crops, when planted in standing corn, are one such practice that can effectively pull nitrate from below the root zone to the top layer of soil, thus limiting the amount of potential nitrate leaching to groundwater. Irrigation management that would lower average soil moisture conditions also could potentially limit nitrogen transport. Limiting the leaching of nitrate will continue to be a challenge in sandy soils of the eastern part of the Mid-Atlantic Coastal Plain, where soil moisture capacity is relatively low and managing irrigation around rainfall is difficult.

\section{References Cited}

Agostini, F., Tei, F., Silgram, M., Farneselli, M., Benincasa, P., and Aller, M.F., 2010, Decreasing nitrate leaching in vegetable crops with better $\mathrm{N}$ management, in Lichtfouse, E., ed.,: Genetic Engineering, Biofertilisation, Soil Quality and Organic Farming, v. 14, p. 147-200, accessed December 14, 2017, at https://doi.org/10.1007/978-90-481-8741-6_6.

Al-Kaisi, Mahdi, and Yin, Xinhua, 2003, Effects of nitrogen rate, irrigation rate, and plant population on corn yield and water use efficiency: Agronomy Journal, v. 95, no. 6, p. 1475-1482, accessed October 24, 2017, at https://doi. org/10.2134/agronj2003.1475.

Andres, A.S., 1991, Results of the coastal Sussex County, Delaware ground-water quality survey: Delaware Geological Survey Report of Investigations No. 49, 28 p., accessed December 14, 2017, at http://udspace.udel.edu/bitstream/ handle/19716/3164/RI49.pdf? sequence $=1$ andisAllowed $=\mathrm{y}$.

Andres, A.S., 1994, Geohydrology of the Seaford area, Delaware: Delaware Geological Survey Hydrologic Map No. 9, 1:24,000, accessed December 14, 2017, at http://www.dgs.udel.edu/publications/hm9-geohydrologyseaford-area-delaware.
Andres, A.S., and Klingbeil, A.D., 2006, Thickness and transmissivity of the unconfined aquifer of Eastern Sussex County, Delaware: Delaware Geological Survey Report of Investigations No. 70, 25 p., accessed December 14, 2017, at https://www.dgs.udel.edu/publications/ri70-thicknessand-transmissivity-unconfined-aquifer-eastern-sussexcounty-delaware.

Ator, S.W., and Denver, J.M., 2015, Understanding nutrients in the Chesapeake Bay watershed and implications for management and restoration-The Eastern Shore: U.S. Geological Survey Circular 1406, 72 p., accessed December 14, 2017, at https://dx.doi.org/10.3133/cir1406.

Böhlke, J.K., 2002, Groundwater recharge and agricultural contamination: Hydrogeology Journal, v. 10, no. 1, p. 153-179, accessed December 14, 2017, at https://doi. org/10.1007/s10040-001-0183-3.

Böhlke, J.K., and Denver, J.M., 1995, Combined use of groundwater dating, chemical and isotopic analyses to resolve the history and fate of nitrate contamination in two agricultural watersheds, Atlantic Coastal Plain, Maryland: Water Resources Research, v. 31, no. 9, p. 2319-2339, DOI: 10.1029/95WR01584, accessed December 14, 2017, at http:/onlinelibrary.wiley.com/doi/10.1029/95WR01584/ abstract.

Brady, N.C., and Weil, R.R., 2008, The nature and properties of soils (14th ed.): New York, Macmillan Publishing Co., $965 \mathrm{p}$.

Busenberg, Eurybiades, and Plummer, L.N., 1992, Use of Chlorofluorocarbons $\left(\mathrm{CC}_{13} \mathrm{~F}\right.$ and $\left.\mathrm{CC}_{12} \mathrm{~F}_{2}\right)$ as hydrologic tracers and age-dating tools: The alluvium and terrace system of central Oklahoma: Water Resources Research, v. 28, no. 9, p. 2257-2283, accessed December 14, 2017, at http://onlinelibrary.wiley.com/doi/10.1029/92WR01263/pdf.

Busenberg, Eurybiades, and Plummer, L.N., 2000, Dating young ground water with sulfur hexafluoride: Natural and anthropogenic sources of sulfur hexafluoride: Water Resources Research, v. 36, no. 10, p. 3011-3030, accessed June 10, 2018, at https://doi.org/10.1029/2000WR900151.

Bushong, J.T., Miller, E.C., Mullock, J.L., Arnall, D.B., and Raun, W.R., 2014, Effect of irrigation and preplant nitrogen fertilizer source on maize in the Southern Great Plains: International Journal of Agronomy, v. 2014, 10 p., accessed October 24, 2017, at https://doi.org/10.1155/2014/247835.

Casciotti, K.L., Sigman, D.M., Hastings, M.G., Böhlke, J.K., and Hilkert, A., 2002, Measurement of the oxygen isotopic composition of nitrate in seawater and freshwater using the dentirifier method: Analytical Chemistry, v. 74, no. 19, p. 4905-4912, accessed October 24, 2017, at https://doi.org/10.1021/ac020113w. 
Clune, J.W., and Denver, J.M., 2012, Residence time, chemical and isotopic analysis of nitrate in the groundwater and surface water of a small agricultural watershed in the Coastal Plain, Bucks Branch, Sussex County, Delaware: U.S. Geological Survey Scientific Investigations Report 2012-5235, 15 p., accessed December 14, 2017, at https://pubs.usgs.gov/sir/2012/5235/.

Cunningham, W.L., and Schalk, C.W., comps., 2011, Groundwater technical procedures of the U.S. Geological Survey: U.S. Geological Survey Techniques and Methods 1-A1, 151 p., accessed December 14, 2017, at https://pubs.usgs.gov/tm/1a1/ [online only].

Dean, J.E., and Weil, R.R., 2009, Brassica cover crops for nitrogen retention in the Mid-Atlantic Coastal Plain: Journal of Environmental Quality, v. 38, no. 2, p. 520-528, accessed October 24, 2017, at https://doi.org/10.2134/jeq2008.0066.

Delaware Department of Agriculture, 2017, Grants and Loans, accessed on December 27, 2017, at https://dda.delaware. gov/financial_assistance.shtml.

Delaware Department of Natural Resources and Environmental Control, 2017, The State of Delaware 2016 combined watershed assessment report (305(b) and Determination of the Clean Water Act Section 303(b) list of waters needing TMDLs, accessed on December 27, 2017, at http://regulations.delaware.gov/AdminCode/ title7/7000/7400/7406.shtml\#TopOfPage.

Delaware Water Quality Portal, 2017, Historical data for 304381: Delaware Water Quality Portal, accessed January 8, 2018, at http://demac.udel.edu/waterquality/wq_layout. php?stationid=21DELAWQ_WQX-304381.

Denver, J.M., 1986, Hydrogeology and geochemistry of the unconfined aquifer, West-Central and Southwestern Delaware: Delaware Geological Survey Report of Investigations No. 41, 100 p., accessed December 14, 2017, at http://www.dgs.udel.edu/sites/default/files/publications/ rfi41.pdf.

Denver, J.M., 1989, Effects of agricultural practices and septic-system effluent on the quality of water in the unconfined aquifer in parts of eastern Sussex County, Delaware: Delaware Geological Survey Report of Investigations No. 45, 66 p., accessed December 14, 2017, at http://www.dgs.udel.edu/sites/default/files/publications/ ri45.pdf.

Denver, J.M., Ator, S.W., Debrewer, L.M., Ferrari, M.J., Barbaro, J.R., Hancock, T.C., Brayton, M.J., and Nardi, M.R., 2004, Water quality in the Delmarva Peninsula, Delaware, Maryland, and Virginia, 1999-2001: U.S. Geological Survey Circular 1228, 40 p., accessed December 17, 2017, at https://pubs.usgs.gov/circ/2004/1228/.
Denver, J.M., Tesoriero, A.J., and Barbaro, J.R., 2010, Trends and transformation of nutrients and pesticides in a Coastal Plain aquifer system, United States: Journal of Environmental Quality, v. 39, no. 1, p. 154-167, accessed June 18, 2018, at https://doi.org/10.2134/jeq2009.010.

Eck, H., 1984, Irrigated corn yield response to nitrogen and water: Agronomy Journal, v. 76, accessed October 24, 2017, at https://pubag.nal.usda.gov/pubag/downloadPDF. $\mathrm{xhtml}$ ?id=502\&content $=$ PDF.

Eckhardt, K., 2005, How to construct recursive digital filters for baseflow separation: Hydrological Processes, v. 19, no. 2, p. 507-515, doi:10.1002/hyp.5675, accessed January 14, 2014, at http://dx.doi.org/10.1002/hyp.5675.

Hamilton, P.A., Denver, J.M., Phillips, P.J., and Shedlock, R.J., 1993, Water-quality assessment of the Delmarva Peninsula, Delaware, Maryland, and Virginia-Effects of agricultural activities on, and the distribution of, nitrate and other inorganic constituents in the surficial aquifer: U.S. Geological Survey Open-File Report 93-40, 95 p., accessed December 14, 2017, at https://pubs.usgs.gov/of/1993/0040/ report.pdf.

Homer, C.G., Dewitz, J.A., Yang, L., Jin, S., Danielson, P., Xian, G., Coulston, J., Herold, N.D., Wickham, J.D., and Megown, K., 2015, Completion of the 2011 National Land Cover Database for the conterminous United States-Representing a decade of land cover change information. Photogrammetric Engineering and Remote Sensing, v. 81, no. 5, p. 345-354, accessed January 8, 2018, at https://www.mrlc. gov/nlcd2011.php.

Jackson, L.E., Wyland, L.J., and Stivers, L.J., 1993, Winter cover crops to minimize nitrate losses in intensive lettuce production: Journal of Agricultural Science, v. 121, p. 55-62, accessed October 24, 2017, at http://ucanr.edu/ sites/Jackson_Lab/files/155592.pdf.

Kasper, J.W., 2014, Delaware's 2014 305(b) GroundwaterQuality Assessment Based on Public-Well Data: Results of Sampling, 2012-13, accessed October 24, 2014, at http://www.dnrec.delaware.gov/swc/wa/Documents/WAS/ dave\%27s\%20docs/305b_GW_2014_FINAL.PDF.

Kim, K.I., Clay, D.E., Carlson, C.G., Clay, S.A., and Trooien, T., 2008, Do synergistic relationships between nitrogen and water influence the ability of corn to use nitrogen derived from fertilizer and soil?: Agronomy Journal, v. 100, no. 3, p. 551-556, accessed October 24, 2017, at https://doi.org/10.2134/agronj2007.0064.

Kristensen, H.L., and Thorup-Kristensen, K., 2004, Root growth and nitrate uptake of three different catch crops in deep soil layers: Soil Science Society of America Journal, v. 68 , no. 2, p. 529-537, accessed October 24, 2017, at https://doi.org/10.2136/sssaj2004.5290. 
Lainé, P., Ourry, A., Macduff, J., Boucaud, J., and Salette, J., 1993, Kinetic parameters of nitrate uptake by different catch crop species: effects of low temperatures or previous nitrate starvation: Physiologia Plantarum, v. 88, no. 1, p. 85-92, accessed December 14, 2017, at http://onlinelibrary.wiley. com/doi/10.1111/j.1399-3054.1993.tb01764.x/abstract.

Lindsey, B.D., Phillips, S.W., Donnelly, C.A., Speiran, G.K., Plummer, L.N., Böhlke, J.K., Focazio, M.J., Burton, M.C., and Busenberg, Eurybiades, 2003, Residence times and nitrate transport in ground water discharging to streams in the Chesapeake Bay watershed: U.S. Geological Survey Water-Resources Investigations Report 03-4035, 201 p., accessed December 14, 2017, at https://pa.water.usgs.gov/ reports/wrir03-4035.pdf.

Olson, R.A., Dreier, A.F., Thompson, C., Frank, K., and Grabouski, P., 1964, Using fertilizer nitrogen effectively on grain crops: Bulletin of the Agricultural Experiment Station of Nebraska, Station Bulletin SB 479, accessed October 24, 2017, at http://digitalcommons.unl.edu/agronomyfac$\mathrm{pub} / 553 /$.

Randall, G.W., and Mulla, D.J., 2001, Nitrate nitrogen in surface waters as influenced by climatic conditions and agricultural practices: Journal of Environmental Quality, v. 30, no. 2, p. 337-344, accessed October 24, 2017, at https://doi.org/10.2134/jeq2001.302337x.

Ritter, W.F., and Chirnside, A.E.M., 1982, Groundwater quality in selected areas of Kent and Sussex Counties, Delaware: Dover, Delaware. Technical Report, Delaware Department of Natural Resources and Environmental Control, $229 \mathrm{p}$.

Ritter, W.F., Scarborough, R.W., and Chirnside, A.E.M., 1991, Nitrate leaching under irrigation on Coastal Plain soil: Journal of Irrigation and Drainage Engineering, v. 117, no. 4, p. 490-502, accessed October 24, 2017, at https://doi. org/10.1061/(ASCE)0733-9437(1991)117:4(490).

Ritter, W.F., Scarborough, R.W., and Chirnside, A.E.M., 1993, Nitrate leaching under irrigated corn: Journal of Irrigation and Drainage Engineering, v. 119, no. 3, p. 544-553, accessed October 24, 2017, at http://ascelibrary.org/doi/ abs/10.1061/(ASCE)0733-9437(1993)119:3(544).

Sanford, W.E., Pope, J.P., Selnick, D.L., and Strumvoll, R.F., 2012, Simulation of groundwater flow in the shallow aquifer system of the Delmarva Peninsula, Maryland and Delaware: U.S. Geological Survey Open-File Report 2012-1140, 58 p., accessed December 14, 2017, at http://pubs.usgs.gov/ of/2012/1140 [online only].

Sauer, V.B., and Turnipseed, D.P., 2010, Stage measurement at gaging stations: U.S. Geological Survey Techniques and Methods, book 3, chap. A7, 45 p., accessed October 24, 2017, at http://pubs.usgs.gov/tm/tm3-a7/.
Shedlock, R.J., Denver, J.M., Hayes, M.A., Hamilton, P.A., Koterba, M.T., Bachman, L.J., Phillips, P.J., and Banks, W.S., 1999, Water-quality assessment of the Delmarva Peninsula, Delaware, Maryland, and Virginia; results of investigations, 1987-91: U.S. Geological Survey WaterSupply Paper 2355-A, accessed December 14, 2017, at https://pubs.er.usgs.gov/publication/wsp2355A.

Sigman, D.M., Casciotti, K.L., Andreani, M., Barford, C., Galanter, M., and Böhlke, J.K., 2001, A bacterial method for the nitrogen isotopic analysis of nitrate in seawater and freshwater: Analytical Chemistry, v. 73, no. 17, p. 41454153, accessed October 24, 2017, at https://doi.org/10.1021/ ac010088e.

Singh, Shatrugan, Inamdar, Sheeram, and Scott, Durelle, 2013, Comparison of two PARAFAC models of dissolved organic matter fluorescence for a Mid-Atlantic forested watershed in the USA: Journal of Ecosystems, v. 2013, 16 p., accessed October 24, 2017, at https://doi.org/10.1155/2013/532424.

Soil Survey Staff, Natural Resources Conservation Service, U.S. Department of Agriculture, 2016, Web Soil Survey, accessed December 14, 2017, at https://websoilsurvey. sc.egov.usda.gov/app/Help/Citation.htm.

Soroka, A.M., and Denver, J.M., 2018, Chemistry analysis results for water, soil-pore water, soil and plant material collected from two agricultural sites in the Nanticoke and Chester River watersheds on the Delmarva Peninsula from 2013 to 2016: U.S. Geological Survey data release, https://doi.org/10.5066/F77H1HK5.

Spahr, N.E., Dubrovsky, N.M., Gronberg, J.M., Franke, O.L., and Wolock, D.M., 2010, Nitrate loads and concentrations in surface-water base flow and shallow groundwater for selected basins in the United States, water years 1990-2006: U.S. Geological Survey Scientific Investigations Report 2010-5098, [variously paged], accessed December 14, 2017, at https://pubs.usgs.gov/sir/2010/5098/pdf/SIR105098.pdf.

Staver, K.W., and Brinsfield, R.B., 1998, Using cereal grain winter cover crops to reduce groundwater nitrate contaminaniton in the mid-atlantic Coastal Plain: Journal of Soil and Water Conservation, v. 53, no. 3, p. 230-240, accessed December 14, 2017, at http://www.jswconline.org/content $/ 53 / 3 / 230$.abstract?ijkey $=0 \mathrm{fe} 17 \mathrm{afb} 893$ faf $25 \mathrm{e} 3 \mathrm{bc} 525798$ 735d68cab77394\&keytype2=tf_ipsecsha.

University of Delaware, 2017, Delaware Environmental Observing System, accessed January 2, 2018, at http://www.deos.udel.edu.

University of Delaware, College of Agriculture and Natural Resources, 2017, Extension, accessed on December 27, 2017, at http://extension.udel.edu/ag/. 
U.S. Department of Agriculture, National Agricultural Statistics Service, 2012, 2012 Census of Agriculture-County data, Delaware irrigation: 2012 and 2007, 18(D), accessed December 10, 2016, at https://www.agcensus.usda.gov/Publications/2012/Full_Report/Volume_1,_Chapter_2_County_ Level/Delaware/st10_2_010_010.pdf.

U.S. Environmental Protection Agency, 1993, Method 351.2, Revision 2.0: Determination of Total Kjeldahl Nitrogen by semi-automated colorimetry, accessed August 29, 2015, at https:/www.epa.gov/sites/production/files/2015-08/documents/method_351-2_1993.pdf.

U.S. Geological Survey, variously dated, National field manual for the collection of water-quality data: U.S. Geological Survey Techniques of Water-Resources Investigations, book 9, chaps. A1-A10, accessed December 14, 2017, at http://pubs.water.usgs.gov/twri9A.

U.S. Geological Survey, National Water Information System (NWIS) data (USGS Water Data for the Nation), accessed October 24, 2017, at https://waterdata.usgs.gov/nwis.
Wagner, R.J., Boulger, R.W., Jr., Oblinger, C.J., and Smith, B., 2006, Guidelines and standard procedures for continuous water-quality monitors: Station operation, record computation, and data reporting: U.S. Geological Survey Techniques and Methods, 1-D3, [variously paged], accessed December 10, 2016, at https://pubs.usgs.gov/tm/2006/tm1D3/pdf/ TM1D3.pdf.

Weinert, T.L., Pan, W.L., Moneymaker, M.R., Santo, G.S., and Stevens, R.G., 2002, Nitrogen recycling by nonleguminous winter cover crops to reduce leaching in potato rotations: Agronomy Journal, v. 94, no. 2, p. 365-372, accessed December 14, 2017, at https://dl.sciencesocieties.org/publications/aj/abstracts/94/2/365.

Zhang, Y.-M., Hu, C.-S., Zhang, J.-B., Chen, D.-L., and Li, X.-X., 2005, Nitrate leaching in an irrigated wheatmaize rotation field in the north China plain: Pedosphere, v. 15, no. 2, p. 196-203, accessed December 14, 2017, at http://pedosphere.issas.ac.cn/trqen/ch/reader/view_abstract. aspx?file_no=20050207\&flag=1. 

For more information, contact:

Director, MD-DE-DC Water Science Center

U.S. Geological Survey

5522 Research Park Drive

Baltimore, MD 21228

or visit our website at:

http://md.water.usgs.gov/

Publishing support provided by the West Trenton and Pembroke Publishing Service Centers 
